DOI: $10.5800 /$ GT-2021-12-3-0537

\title{
VOLUMETRIC AND SPATIAL SEGMENTATION OF THE TIEN SHAN LITHOSPHERE ACCORDING TO GEOPHYSICAL DATA
}

\author{
A.K. Rybin $\odot$, E.A. Bataleva ${ }^{\circledR}$, K.S. Nepeina $\odot$, V.E. Matyukov $\odot$
}

Research Station, Russian Academy of Science, Bishkek 720049, Kyrgyzstan

\begin{abstract}
This article consolidates the results of studying the deep structure of the lithosphere of the Central Tien Shan, which aimed to identify the main tectonic elements in its geophysical models. We have compared the structural and geological data with the information on the deep structure obtained by geophysical methods and from the positions of earthquake hypocenters in the study area. According to geological concepts, the Tien Shan orogenic belt is characterized by longitudinal and transverse segmentation. The boundaries of the Northern, Middle, Southern Western and Eastern segments of the Tien Shan are deep-seated fault structures. In deep faults and channels of heat and mass transfer, endogenous processes are localized. High-velocity, geoelectrical and thermal models consider such faults and channels as contrasting objects that can be referred to as indicators of these processes.

Our analysis of the locations of earthquake hypocenters from NNC, KNET, CAIIG, KRNET, SOME catalogues shows that seismic events are strongly confined to the fault zones and the boundaries of large blocks. A correlation between the anomalies of geophysical fields suggests the degree of inheritance of tectonic structures and the boundaries of the main tectonic segments of the Tien Shan. To compare the crustal and upper mantle heterogeneities reflected in different geophysical fields, we have analyzed seismic tomographic sections based on volumetric seismotomographic models geoelectric and velocity sections along profiles across the main tectonic elements of the study area. The sections are used to identify the zones with relatively low (i.e. reduced) seismic wave velocities and detect the deep-seated longitudinal segmentation of the folded belt. Objects showing anomalous seismic wave velocities are found in the seismotomographic sections at all the depths under consideration. The most contrasting differences in the velocities of P-and S-waves are typical of the depths of 0-5 km and 50-65 km, showing the most clearly observed Northern, Southern and Western segments of the Tien Shan. In general, the velocities of P-and S-waves at the Northern Tien Shan are higher than those at the Middle and Southern segments. We have analyzed the distribution of geoelectric heterogeneities identified from magnetotelluric sounding data in order to determine the boundaries of the main tectonic elements that are considered as the zones of increased electrical conductivity confined to the boundaries of the fault structures. The distribution of earthquake epicenters clearly reflects the segmentation of the Tien Shan into the Northern, Middle and Southern segments and shows the Western and Eastern Tien Shan relative to the Talas-Fergana fault. Ourstudies of the crust and the upper mantle of the Tien Shan have confirmed that the abovementioned tectonic segments have differences in their deep structures Based on a comprehensive analysis of the study results, we can qualitatively identify a relationship between the distribution of the velocity and geoelectric heterogeneities in the crust and upper mantle, seismicity and the stress-strain state of the crust.
\end{abstract}

KEYWORDS: seismotomographic section; geoelectric heterogeneities of the crust and upper mantle; Moho boundary; segmentation of the Tien Shan orogenic belt

FUNDING: The geological and geophysical materials on the deep structure of the crust and upper mantle of the Central Tien Shan were collected and analyzed under Project 16-17-10059 supported by the Russian Science Foundation. For the comprehensive analysis of geological and geophysical information, the data on the Northern Tien Shan were prepared under the state assignment of the Research Station RAS in Bishkek for 2019-2021, which was funded by the RF Ministry of Science and Higher Education (project AAAA-A19-119020190063-2).

FOR CITATION: Rybin A.K., Bataleva E.A., Nepeina K.S., Matyukov V.E., 2021. Volumetric and spatial segmentation of the Tien Shan lithosphere according to geophysical data. Geodynamics \& Tectonophysics 12 (3), 508-543. doi:10.5800/GT-2021-12-3-0537 


\title{
ОБЪЕМНО-ПРОСТРАНСТВЕННАЯ СЕГМЕНТАЦИЯ ЛИТОСФЕРЫ ТЯНЬ-ШАНЯ ПО ДАННЫМ ГЕОФИЗИЧЕСКИХ ИССЛЕДОВАНИЙ
}

\author{
А.К. Рыбин, Е.А. Баталева, К.С. Непеина, В.Е. Матюков
}

Научная станция РАН, 720049, Бишкек, Кыргызстан

АНнотАЦИЯ. Статья посвящена обобщению результатов изучения глубинного строения литосферы Центрального Тянь-Шаня с целью выявления основных тектонических элементов в существующих геофизических моделях. Приведены результаты сопоставления данных структурно-геологических исследований с данными о глубинном строении, полученными комплексом геофизических методов, и положением гипоцентров землетрясений. Согласно геологическим представлениям Тянь-Шаньский орогенический пояс характеризуется продольной и поперечной сегментацией. Границами Северного, Срединного и Южного Тянь-Шаня, а также Западного и Восточного служат разломные структуры глубинного заложения. Глубинные разломы и каналы тепломассоперетока характеризуются обособленным (локализованным) проявлением эндогенных процессов, представляют собой контрастные объекты в скоростных, геоэлектрических, тепловых моделях и могут служить индикаторными признаками. Анализ каталогов (NNC, KNET, CAIIG, KRNET, SOME) на предмет расположения гипоцентров очагов землетрясений показывает высокую степень пространственной приуроченности сейсмических событий к разломным зонам и границам крупных блоков. Корреляция аномалий геофизических полей позволяет установить степень унаследованности тектонических структур и выявить границы основных тектонических сегментов Тянь-Шаня. Для сопоставления коровых и верхнемантийных неоднородностей, выраженных в различных геофизических полях, проанализированы сейсмотомографические срезы, построенные на основе объемных сейсмотомографических моделей, геоэлектрические и скоростные разрезы вдоль профилей, секущих основные тектонические элементы Тянь-Шаня. Обзор построенных разрезов позволил определить области относительно низкоскоростных зон (с пониженными скоростями сейсмических волн) и глубинные проявления продольной сегментации складчатого пояса. Во всем интервале рассматриваемых глубин на сейсмотомографических срезах наблюдаются аномальные скоростные объекты. Наиболее контрастными по перепаду скоростей продольных и поперечных сейсмических волн являются срезы на глубине 0-5 км и 50-65 км, где наиболее ярко прослеживается масштабная сегментация Тянь-Шаня на северный, южный и западный сегменты. В целом, скорости P- и S-волн для Северного Тянь-Шаня выше скоростей Срединного и Южного. Анализ распределения геоэлектрических неоднородностей, полученных при исследовании Тянь-Шаня методом магнитотеллурического зондирования, позволил определить границы основных тектонических элементов как зоны повышенной электропроводности, приуроченные к границам разломных структур. В распределении эпицентров землетрясений четко проявляются зоны Северного, Срединного и Южного Тянь-Шаня, а также проявляется сегментация Западного и Центрального Тянь-Шаня относительно Таласо-Ферганского разлома. Выполненные исследования земной коры и верхней мантии Тянь-Шаня подтвердили существование различий в глубинном строении между рассматриваемыми тектоническими сегментами. Комплексный анализ полученных результатов позволил на качественном уровне выявить взаимосвязь между распределением скоростных и геоэлектрических неоднородностей в земной коре и верхней мантии, сейсмичностью и напряженно-деформированным состоянием земной коры.

КЛЮЧЕВЫЕ СЛОВА: сейсмотомографический разрез; геоэлектрические неоднородности земной коры и верхней мантии; граница Мохо; сегментация Тянь-Шаньского орогенического пояса

ФИНАНСИРОВАНИЕ: Статья подготовлена при поддержке РНФ, проект № 16-17-10059 - Сбор и анализ геологогеофизических материалов о глубинном строении земной коры и верхней мантии Центрального Тянь-Шаня. Подготовка данных для комплексного анализа геолого-геофизической информации о территории Северного Тянь-Шаня осуществлялась в рамках выполнения государственного задания Федерального государственного бюджетного учреждения науки Научной стации РАН в г. Бишкеке на 2019-2021 годы (регистрационный номер AАAА-А19119020190063-2).

\section{1. ВВЕДЕНИЕ}

Тянь-Шань представляет собой один из крупнейших внутриконтинентальных орогенов Евразии и является ключевым объектом для понимания современных геодинамических процессов и эволюции Центрально-Азиатского складчатого пояса [Bakirov, Maksumova, 2001; Mossakovsky et al., 1993; Windley et al., 2007].
История геолого-геофизического изучения Тянь-Шаня насчитывает более 100 лет, однако до настоящего времени существует достаточно много неопределенности в интерпретации глубинного строения и геодинамической эволюции региона. Подавляющее большинство исследователей считают, что внутриконтинентальный ороген Тянь-Шаня сформировался в результате 
Индо-Евроазиатской коллизии, но вопросы о природе основных тектонических структур, общем строении орогена, а также о корреляции структур вдоль простирания пояса [Burtman, 2006, 2012; Leonov, 1996; Makarov et al., 2010] до сих пор являются дискуссионными. Существующие противоречия во взглядах, возможно, обусловлены тем, что зачастую исследования в различных регионах Тянь-Шаня проводятся независимо друг от друга из-за принадлежности к различным государствам и практически без учета информации о строении сопредельной территории, полученной коллегами по профессии. Отчасти эти разногласия могут быть разрешены с привлечением результатов геофизических исследований.

Морфология основных структурных элементов, выделенных в геофизических моделях, проявление морфоструктурных ансамблей и закономерности их размещения на различных пространственно-масштабных уровнях, а также поведение и взаимоотношение друг с другом границ и поверхностей раздела, характеризующих тектоническую расслоенность Тянь-Шаня, вызывают постоянный интерес научного сообщества. Современными исследованиями различных авторов установлены общие черты глубинного строения Центрального Тянь-Шаня, которые свидетельствуют о тектонической расслоенности [Makarov, 1977], наличии геофизических поверхностей раздела К0, К1, К2, М [Makarov et al., 2010; Sabitova, 1978; Sabitova et al., 2006; Yudakhin, 1983], поверхности Кюри [Pogrebnoi et al., 2009], существовании корового проводящего слоя [Ваtalev et al., 1989, 1993; Rybin, 2001, 2011; Batalev, 2002; Bataleva, 2005; Bataleva et al., 2006; Trapeznikov et al., 1997]. Обобщения геолого-геофизических исследований для различных территорий Тянь-Шаня (рис. 1) можно найти в работах [Yudakhin, 1983; Trapeznikov et al., 1997; Rybin, 2001, 2011; Mamyrov, 2001; Batalev, 2002; Bataleva, 2005; Buslov et al., 2007; Bragin et al., 2001; Zubovich et al., 2001; Lobanchenko et al., 1988; Makarov et al., 2010; Bataleva, Batalev, 2011a, 2011b, 2011c, 2014a, 2014b; Bataleva et al., 2015]. В настоящей работе приводится комплексный анализ геофизических данных (сейсмических, сейсмологических, электромагнитных и т.д.) (рис. 2) с целью выявления объемно-пространственной сегментации литосферы Тянь-Шаня, выражающейся в построенных геофизических моделях для различных регионов - Северного, Срединного, Южного, а также Западного и Восточного (по отношению к Таласо-Ферганскому разлому) Тянь-Шаня.

На основе проведенного анализа показано, что результаты, полученные различными геофизическими методами, не противоречат, а дополняют друг друга и позволяют выполнить объемно-пространственную

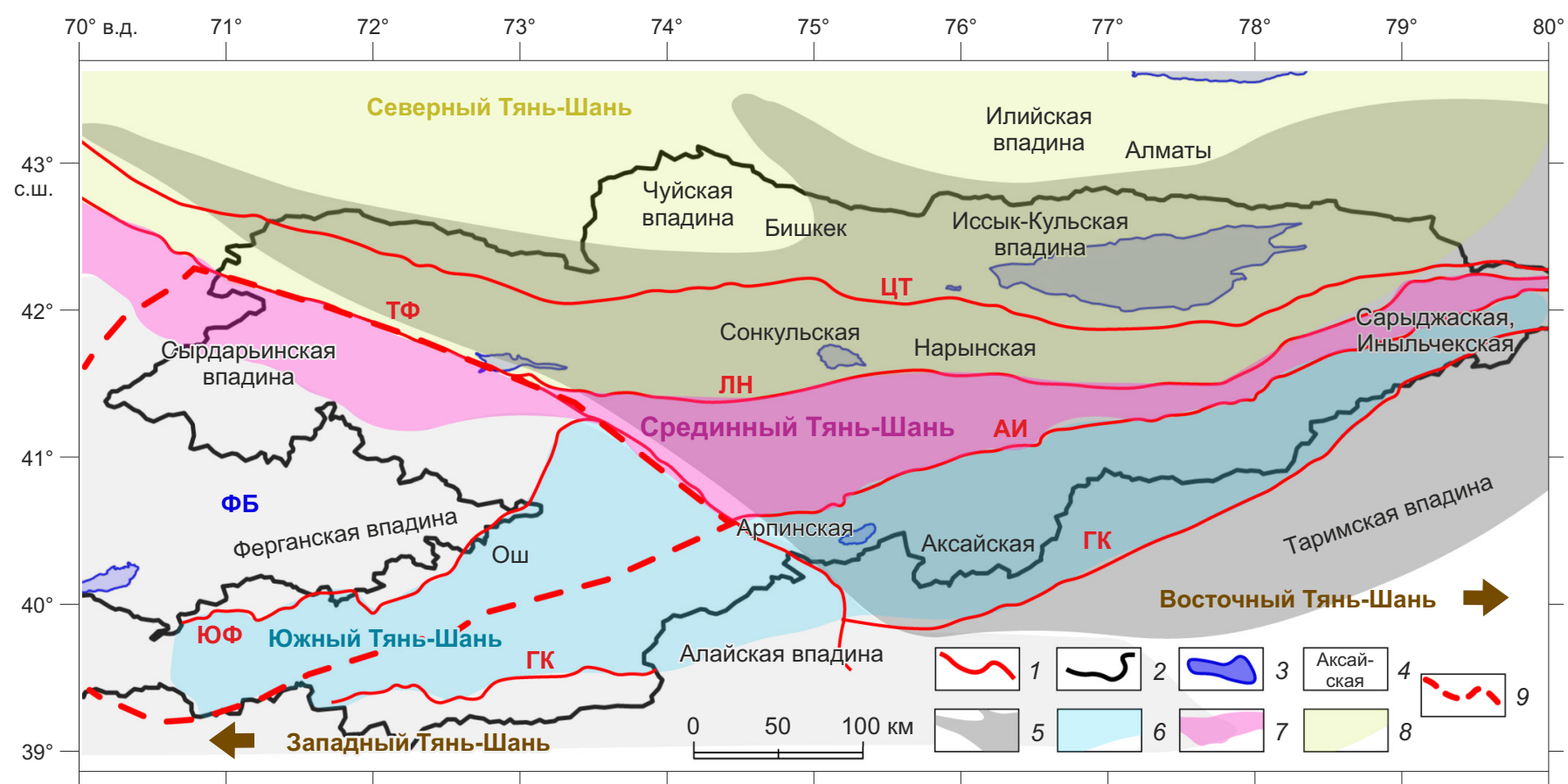

Рис. 1. Главные тектонические элементы Тянь-Шаня и сопредельных территорий (по [Leonov et al., 2016]).

1 - крупнейшие разломы: ТФ - Таласо-Ферганский, ЛН - Линия Николаева, ЦТ - Центрально-Терскейский, АИ - Атбаши-Иныльчекский, ГК - Гиссаро-Кокшаальский, ЮФ - Южно-Ферганский; 2 - границы Киргизской Республики; 3 - озера; 4 - впадины; 5 - зона Центрального Тянь-Шаня согласно делению по [Вurtman, 2006]; 6 - зона Южного Тянь-Шаня; 7 - зона Срединного Тянь-Шаня; 8 - зона Северного Тянь-Шаня; 9 - границы Ферганского блока (ФБ) по [Bazhenov, 1993].

Fig. 1. The main tectonic elements of the Tien Shan and adjacent territories (after [Leonov et al., 2016]).

1 - major faults: ТФ - Talas-Fergana, ЛН - Nikolaev Line, ЦТ - Central Terskey, АИ - Atbashi-Inylchek, ГК - Gissar-Kokshaal, ЮФ - South Fergana; 2 - state borders of the Kyrgyz Republic; 3 - lakes; 4 - basins; 5 - Central Tien Shan (after [Burtman, 2006]); 6 - Southern Tien Shan; 7 - Middle Tien Shan; 8 - Northern Tien Shan; 9 - boundaries of the Fergana block (FB) (after [Bazhenov, 1993]). 
сегментацию литосферы Тянь-Шаня по данным геофизических исследований. Объемно-пространственная сегментация литосферы Тянь-Шаня выполнена с использованием результатов сейсмических, сейсмологических, магнитотеллурических, гравиметрических исследований.

\section{2. СЕЙСМИЧЕСКИЕ И СЕЙСМОЛОГИЧЕСКИЕ ИССЛЕДОВАНИЯ}

Скоростные свойства в исследуемом районе изучались методом глубинного сейсмического зондирования (ГСЗ), методом обменных волн землетрясений (МоB3), методом функции приемника, методом сейсмической томографии и на основе анализа годографов и систем встречных годографов, построенных по данным промышленных взрывов и сильных землетрясений. Глубинные скоростные разрезы земной коры
Тянь-Шаня построены по результатам сети региональных профилей ГСЗ, выполненных на территории Средней Азии (рис. 2). Наиболее пристальное внимание из всех границ раздела, как правило, уделяется границе Мохо. Возможно, это связано с тем, что развитие межгорных и внутригорных впадин в значительной мере обусловлено глубинными процессами в верхней мантии и нижней коре.

Практически во всех существующих геолого-геофизических моделях проявляется граница Мохо, однако глубина ее залегания и морфология поверхности раздела отличается в различных геофизических построениях [Vinnik et al., 2002, 2004; Bragin, Lobanchenko, 2005; Makarov et al., 2010]. Это может быть связано с тем, что исследователи в своих построениях либо опираются на распределение различных физических параметров геологической среды, либо используют расчетные

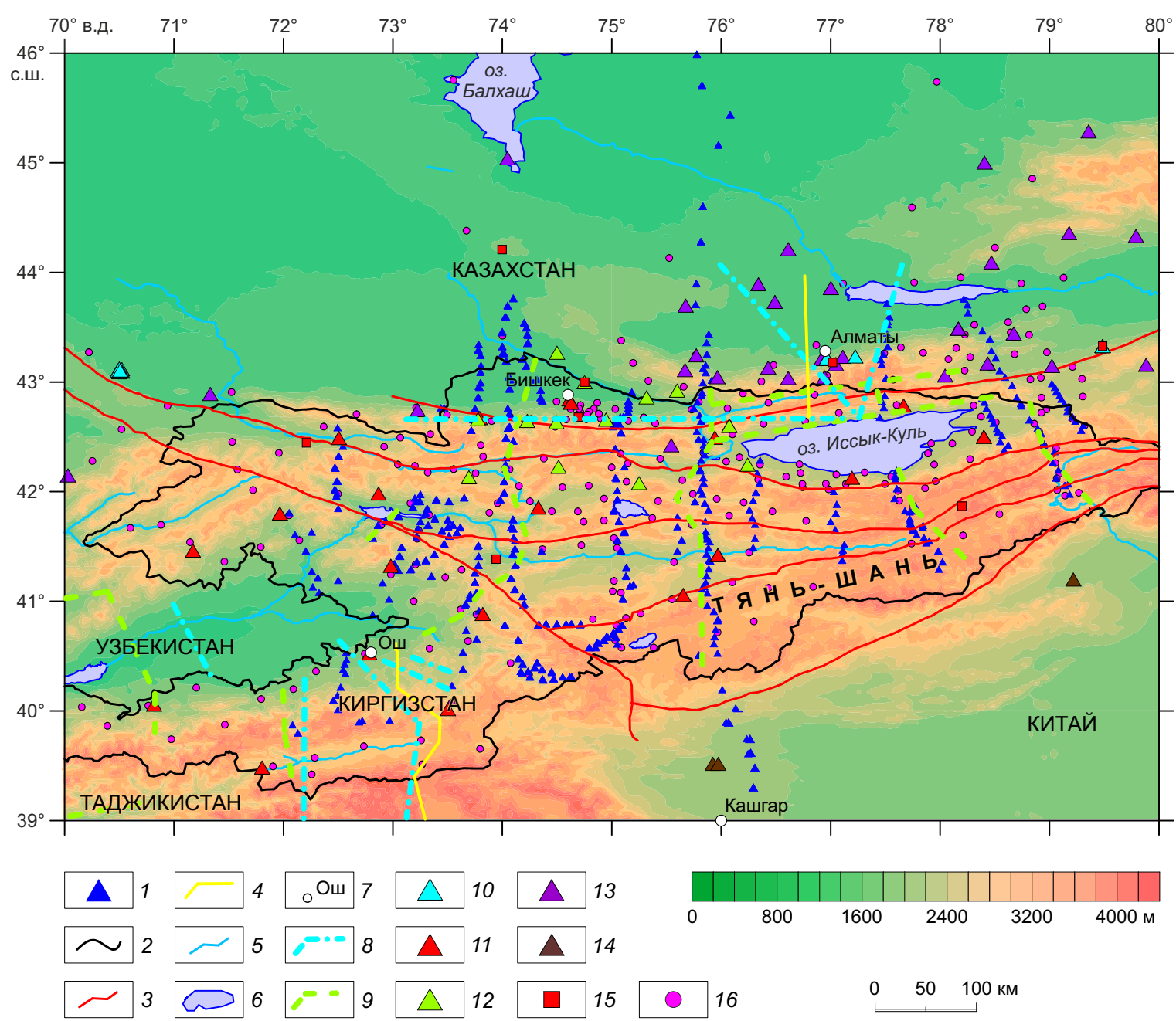

Рис. 2. Схема геолого-геофизической изученности территории Тянь-Шаня.

1 - пункты МТЗ; 2 - границы Киргизской Республики; 3 - крупнейшие разломы; 4 - непрерывное профилирование ГСЗ; 5 реки; 6 - озера; 7 - города; сейсмическое зондирование: 8 - прерывистое профилирование ГСЗ, 9 - профили МОВ3; сейсмические сети: 10 - NNC, 11 - KRNET, 12 - KNET, 13 - SOME, 14 - BJI; GPS-сети: 15 - постоянные, 16 - временные.

Fig. 2. The Tien Shan areas covered by geological and geophysical studies.

1 - MTS points; 2 - state borders of the Kyrgyz Republic; 3 - major faults; 4 - continuous DSS profiling; 5 - rivers; 6 - lakes; 7 - towns; 8 - intermittent DSS profiling, 9 - profiles constructed by the earthquake converted-wave method; seismic networks: 10 - NNC, 11 KRNET, 12 - KNET, 13 - SOME, 14 - BJI; GPS networks: 15 - permanent, 16 - temporary. 
модельные данные и результаты сейсмотомографии. Погрешность определения границы Мохо при этом может достигать $\pm(2-5)$ км.

Более детальному, а следовательно, и более точному изучению распределения пространственно-временных неоднородностей физических параметров земной коры и верхней мантии Тянь-Шаня способствует накопление сведений о глубинном строении по данным ГСЗ и методу отраженных волн землетрясений в модификации общей глубинной точки (МОВЗ-ОГТ), региональной сейсмологии по каталогам сейсмологической сети KNET, гравитационном, электромагнитном и тепловом поле. Этим объясняется широкое использование архивных данных ГСЗ, МОВЗ-ОГТ, каталогов различных сейсмологических сетей, действующих на территории Тянь-Шаня (KNET, KRNET и т.д.), карт распределения геофизических параметров для современных исследований.

В настоящий момент для изучения глубинного строения земной коры и мантии Тянь-Шаня зачастую применяются сейсмотомографические исследования, которые могут представить трехмерную картину распределения плотностных неоднородностей в Земле. Принцип метода состоит в том, что на основе анализа временных невязок, содержащих в себе информацию об аномалиях скоростей на всем пути волны источник - приемник, можно восстановить скоростную структуру, т.е.

$$
d t=\sum_{k} d t_{m k}, d t_{m k}=\frac{l_{m k}}{V_{0 k}+d V_{k}}-\frac{l_{m k}}{V_{0 k}} \cong \frac{l_{m k} d V_{k}}{V_{0 k}^{2}},
$$

где $l_{m k}$ - путь $m$-го луча в $k$-м блоке, $V_{0 k}-$ средняя скорость в слое, в котором расположен $k$-й блок, $d V_{k}$-аномалия скорости в $k$-м блоке.

Сейсмотомографические модели для территории, построенные с использованием цифровых данных, зарегистрированных действующими сейсмологическими сетями [Nepeina, 2018a, 2018b], представлены в работах [Ghose et al., 1998; Adamova, Sabitova, 2004; Bakirov, 2006; Zhiwei et al., 2009; Omuralieva et al., 2009; Koulakov, 2011; Zabelina et al., 2013]. Срезы томографических моделей, представленные на различной глубине (от 5 до 55 км), свидетельствуют о возможности сегментации Тянь-Шаня по распределению объемных плотностных неоднородностей в глубинном строении на Западный и Восточный Тянь-Шань (разделение относительно Таласо-Ферганского разлома), а также области Центрального Тянь-Шаня - на Северный, Срединный и Южный Тянь-Шань.

Рассмотрим подробнее модели скоростей продольных (Vp) и поперечных (Vs) сейсмических волн, построенные для верхней части земной коры Северного Тянь-Шаня, и проанализируем отношения Vp/Vs для этого региона. Такой подход, основанный в большей степени на результатах ГСЗ по двум перпендикулярным друг другу профилям вблизи северной границы Киргизии (рис. 2) - широтному оз. Иссык-Куль - г. Фрунзе Чонкудук (1960) и меридиональному - Каскеленскому профилю (1967) и МОВ3, позволит наиболее детально изучить скоростные характеристики исследуемой территории и сопоставить их с другими геолого-геофизическими данными.

Согласно данным, полученным различными сейсморазведочными методами (корреляционным методом преломленных волн (КМПВ), методом отраженных волн (МОВ), ГСЗ, МОВЗ-ОГТ), для территории Северного Тянь-Шаня под Чуйской впадиной характерны повышенные значения скоростей на глубине 5-25 км, а под Киргизским хребтом - пониженные, примерно на той же глубине [Yudakhin, 1983; Ghose et al., 1998; Sabitova et al., 2003]. Характерной особенностью сейсмического разреза рассматриваемой территории (Чуйская впадина) является зона пониженных скоростей, которая отчетливо проявляется на северо-западе до глубины 12 км (рис. 3). Наиболее ярко она выражена в приповерхностном слое (V=5.1-6.2 км/с) и является пространственно приуроченной к предгорному прогибу, который заполнен мезокайнозойскими отложениями (рис. 4).

Локальные волноводы обнаружены до глубины 20 км как в Чуйской впадине, так и под Киргизским хребтом. Некоторые из них хорошо коррелируют с проводящими зонами, которые установлены по результатам электромагнитных зондирований [Bragin, 2001; Batalev et al., 1989; Rybin et al., 2008]. Природа коровых волноводов, совпадающих с зонами повышенной электропроводности, может быть обусловлена высокой трещиноватостью среды и ее флюидонасыщенностью, что приводит к понижению скоростных свойств.

Практически для всей территории Северного ТяньШаня установлены закономерности в скоростном строении впадин и горных сооружений. Так, под Чуйской, Илийской и Иссык-Кульской впадинами обнаружена скоростная дифференциация, которая выражена в чередовании слоев с повышенными и пониженными скоростями продольных волн в земной коре и верхней мантии, что указывает на ее расслоенность. Наиболее четко различия в скоростном строении для впадин и горных массивов проявляются для Чуйской и Илийской межгорных впадин, для Иссык-Кульской они не настолько ярко выражены.

При детальном рассмотрении скоростных характеристик верхней части земной коры для разных регионов Тянь-Шаня обращает на себя внимание дифференциация продольных и поперечных скоростей, которая, прежде всего, обусловлена физическими свойствами горных пород, слагающими геологические тела и структуры. Если сравнивать скоростные разрезы для Северного, Срединного и Южного Тянь-Шаня, то можно сделать следующие выводы: 1) существует общая тенденция увеличения скоростей с глубиной; 2) скоростные неоднородности наиболее ярко выражены в разрезе верхней части земной коры; 3) для горных хребтов характерна меньшая дифференциация скоростей, чем для межгорных впадин; 4) по сравнению со Срединным и Южным Тянь-Шанем нижней части скоростного разреза 
земной коры Северного Тянь-Шаня присущи самые высокие скорости (6.6-7.0 км/с); 5) минимальные скорости зафиксированы для Таримской впадины.

Смена характера распределения скоростных неоднородностей для всей территории Тянь-Шаня происходит на глубине 20 км. При анализе скоростных свойств земной коры относительно зоны Таласо-Ферганского разлома в средней и нижней коре установлено, что более высокие скорости продольных волн наблюдаются под Западным Тянь-Шанем, а низкие - под Восточным. Для верхней коры характерно обратное распределение скоростей Р-волн - к западу от Таласо-Ферганского (a)

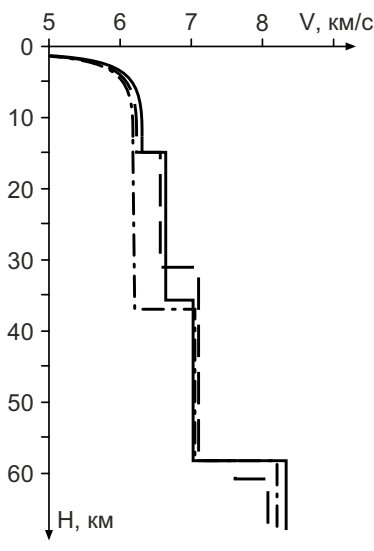

(2)

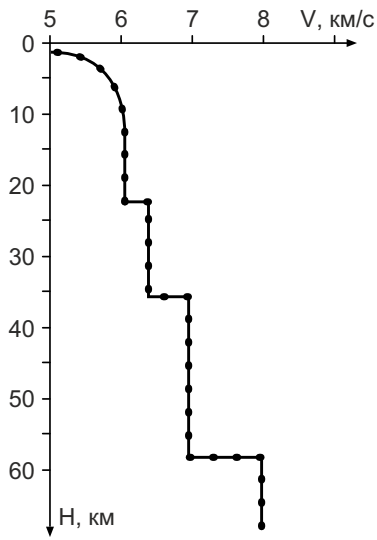

(б)

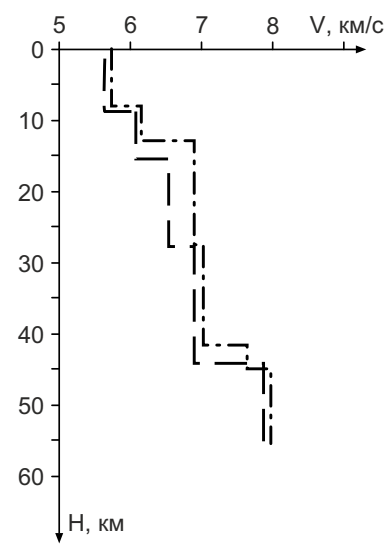

(d)

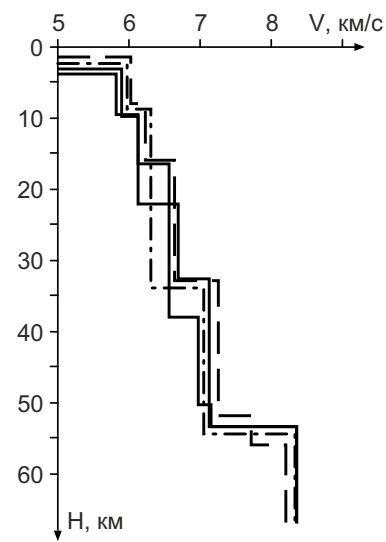

(в)

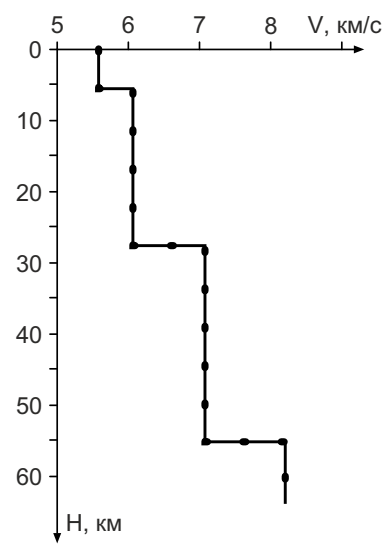

(e)

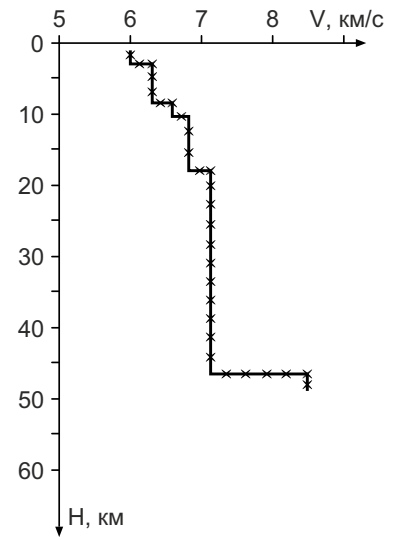

(ж)

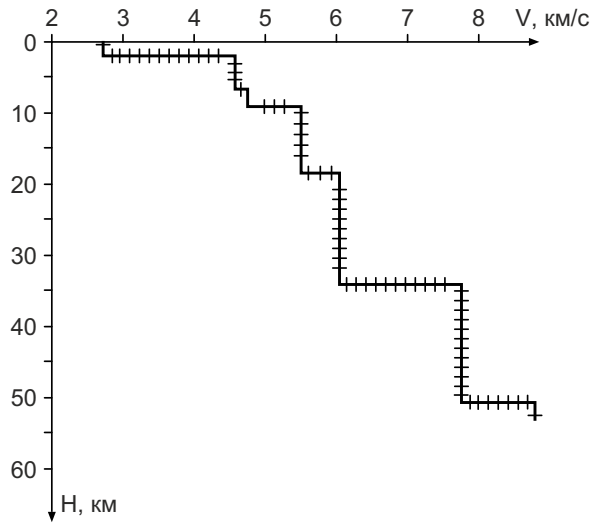

(3)

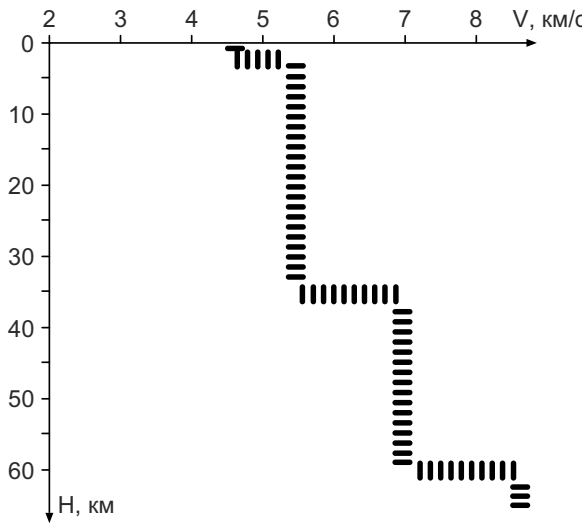

Рис. 3. Скоростные разрезы земной коры Тянь-Шаня.

(a) - район Чаткальского, Атойнокского и Сусамырского хребтов; (б) - Илийская впадина; (в) - Чу-Сарысуйская депрессия; (2) - Иссык-Кульская впадина; (d) - Чуйская впадина [Sabitova, 1978]; (e) - Балхаш-Алакульская впадина (Казахстан); (ж) Ферганская впадина; (з) - Алайская впадина [Volvovsky, Tal-Virsky, 1977]. Несколько графиков по одному району соответствуют наблюдениям на разных профилях [Yudakhin, 1983].

Fig. 3. Seismic wave velocity sections of the crust of the Tien Shan.

(a) - Chatkal, Atoynok and Susamyr ranges; (б) - Ili basin; ( 8 ) - Chu-Sarysuy basin; (2) - Issyk-Kul basin; ( $\partial$ ) - Chuy basin [Sabitova, 1978]; (e) - Balkhash-Alakul basin (Kazakhstan); (※) - Fergana basin; (3) - Alai basin [Volvovsky, Tal-Virsky, 1977]. Several graphs for one region correspond to observations on different profiles [Yudakhin, 1983]. 


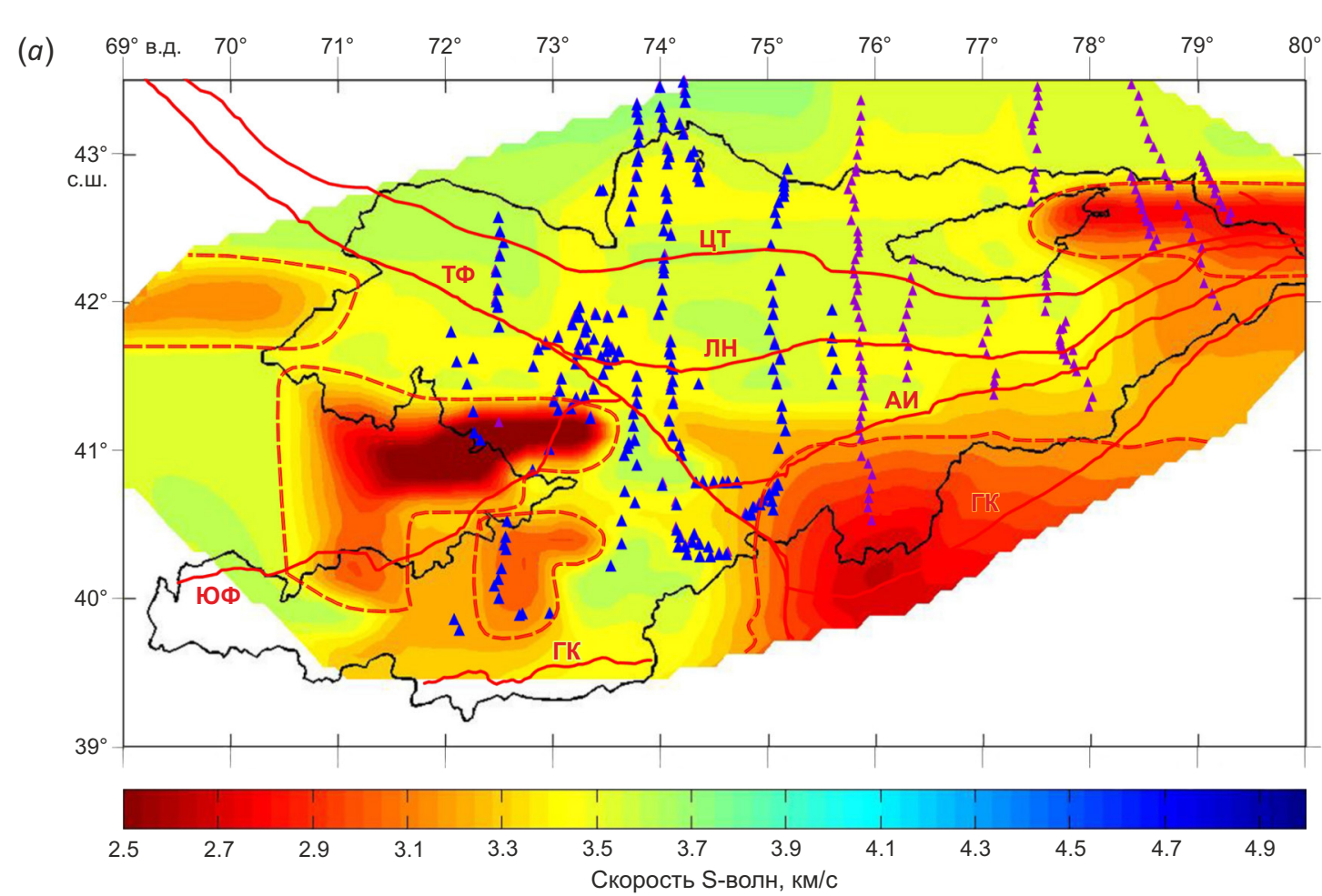

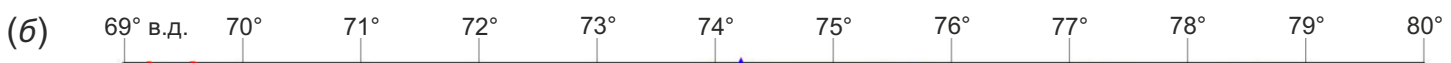
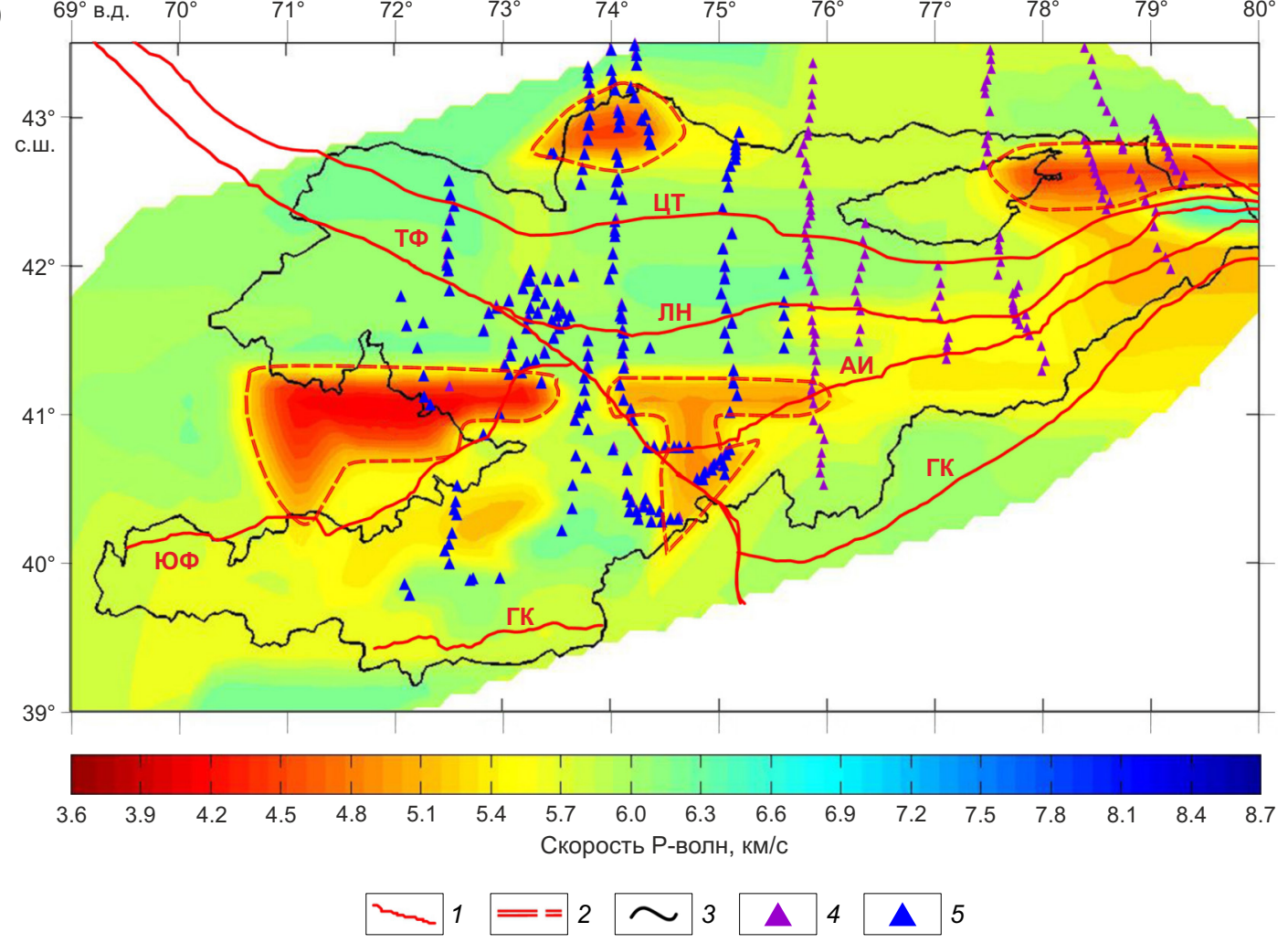

Рис. 4. Дополненная карта среза распределения аномалий сейсмических скоростей (глубина Тянь-Шаня 0-5 км) [Adamova, Sabitova, 2004] для глубин: (a) - S-волн, (б) - Р-волн.

1 - крупнейшие разломы: ТФ - Таласо-Ферганский, ЛН - Линия Николаева, ЦТ - Центрально-Терскейский, АИ - Атбаши-Иныльчекский, ГК - Гиссаро-Кокшаальский, ЮФ - Южно-Ферганский; 2 - низкоскоростные объемы; 3 - границы Киргизской Республики; 4 - пункты МТЗ; 5 - региональные профили МТЗ, рассматриваемые в настоящей работе.

Fig. 4. Completed map of seismic wave velocity anomalies for the depths of 0-5 km of the Tien Shan (after [Adamova, Sabitova, 2004]: (a) - S-waves, (б) - P-waves.

1 - major faults: ТФ - Talas-Fergana, ЛН - Nikolaev Line, ЦТ - Central Terskey, АИ - Atbashi-Inylchek, ГК - Gissar-Kokshaal, ЮФ - South Fergana; 2 - low-velocity volumes; 3 - state borders of the Kyrgyz Republic; 4 - MTS points; 5 - regional MTS profiles considered in this paper. 
разлома скорости ниже, чем к востоку от него [Treusov et al., 1993; Roecker et al.,1993; Adamova, Sabitova, 2004; Bakirov, 2006].

Таким образом, в отношении верхней мантии можно сделать вывод о различном скоростном строении к западу (Западный Тянь-Шань) и востоку (Восточный Тянь-Шань) от Таласо-Ферганского разлома. К западу для мантии характерен классический разрез с возрастанием скоростных характеристик с глубиной. К востоку отмечается наличие протяженных скоростных неоднородностей с аномальными как низкими, так и высокими скоростями Р-волн, разделенных субвертикальными границами. В целом, земная кора Тяньшаньского внутриконтинентального орогена является более низкоскоростной, чем кора сопредельных платформенных областей. Существует мнение [Pogrebnoi, Sabitova, 2001], что присутствие в верхней мантии протяженных по глубине низкоскоростных неоднородностей может служить свидетельством проявления процессов плюм-тектоники. С особенностями скоростного строения земной коры и верхней мантии связано формирование очагов большинства мощных сейсмических событий, которые приурочены либо к зонам высоких градиентов скорости, либо к краевым частям мантийных волноводов.

\section{3. РЕЗУЛЬТАТЫ СЕЙСМОТОМОГРАФИИ}

Сейсмотомографические модели для территории Тянь-Шаня до глубин 200 км, построенные с использованием цифровых данных, зарегистрированных действующими сейсмологическими сетями [Nepeina, 2018a, 2018b], представлены в работах [Roecker et al., 1993; Vinnik et al., 2002, 2004; Kosarev et al., 1993; Kumar et al., 2005; Adamova, Sabitova, 2004; Zhiwei et al., 2009; Omuralieva et al., 2009; Koulakov, 2011; Zabelina et al., 2013; Sychev et al., 2018]. На сегодняшний день для территории Северного Тянь-Шаня методом сейсмической томографии построены три трехмерные скоростные томографические модели.

Детальные исследования скоростной структуры земной коры Тянь-Шаня с применением методов сейсмической томографии были начаты в конце 80-х годов прошлого века, когда появилась возможность использования многочисленных записей землетрясений, полученных за длительный срок функционирования сейсмических станций на территории Киргизии и прилегающих к ней районов [Roecker et al.,1993]. Первая модель трехмерного скоростного строения земной коры Тянь-Шаня была построена в 1993 г. на основе базы данных, зарегистрированных 117 сейсмостанциями. В ней наиболее детально и достоверно представлены районы Северного Тянь-Шаня и часть Южного, расположенная к юго-западу от Таласо-Ферганского разлома, благодаря большому количеству трасс от местных землетрясений, в разной ориентации пересекающих эти районы. Оценка достоверности полученной скоростной модели проводилась путем сравнения сейсмотомографических схем, составленных для одних и тех же областей Тянь-Шаня при использовании различных алгоритмов и при сопоставлении с результатами работ, полученных другими геофизическими методами. На основе интерпретации построенной модели сделаны выводы об отсутствии единых резких скоростных границ большой протяженности внутри земной коры, о существовании различных ее типов в пределах исследуемой территории, о наличии широкого спектра скоростей сейсмических волн в каждом слое, о проявлении инверсионных слоев (волноводов) и их широком развитии в нижнекоровом слое. Наряду с волноводами в земной коре Тянь-Шаня широко развиты зоны повышенных скоростей сейсмических волн [Sabitova, Adamova, 2001]. В этой модели (см. рис. 4) в скоростном поле на разных глубинах (до 50 км) находит отражение Таласо-Ферганский разлом, который служит своеобразной границей между высокоскоростным полем ( $\mathrm{Vp}=6.4$ км/c) к юго-западу от него и менее скоростным - к северо-востоку. На основе построения первой трехмерной сейсмотомографической модели Тянь-Шаня [Roecker et al., 1993] была создана цифровая модель распределения скоростей по профилю вдоль 76-го меридиана. Расчеты скоростной модели в работе основывались на базе массива вступлений Р-волн и $\mathrm{S}$-волн от землетрясений, зарегистрированных за период с 1977 до 1992 г. Характерными особенностями этой модели является слой пониженных скоростей продольных сейсмических волн $V p=5.5-5.9$ км/с на глубинах $~ 50$ км. Особое внимание в сейсмотомографических моделях уделяется вертикальным как низкоскоростным, и так высокоскоростным объемам верхней мантии, расположенным, как правило, под горными сооружениями (рис. 5, 6, 7) и под впадинами соответственно. На построенных меридиональных разрезах ([Laverov, Makarov, 2005, часть II.6]), например «Нарын» (рис. $\left.8, \lambda=76^{\circ}\right)$, а также вдоль профиля «MANAS» (рис. 9, в) очевидно различие скоростной структуры коры - в отличие от горных сооружений, под впадинами, расположенными над высокоскоростной мантией, фиксируется высокоскоростная кора, характерная для платформенных областей. В земной коре при этом отмечается постепенное нарастание скорости с глубиной.

В работах [Adamova, Sabitova, 2004; Adamova et al., 2006] представлена вторая модель (см. рис. 6), в которой были использованы результаты регистрации региональных ( $\Delta<1000$ км) телесейсмических землетрясений (3579 событий) и 27 ядерных взрывов ( $\Delta<10000$ км). Рассмотрим подробнее томографические модели скоростей продольных (P) и поперечных (S) сейсмических волн для верхней части коры под Северным Тянь-Шанем. Составленные срезы до глубины 80 км показывают распределение скоростных неоднородностей. Основные поверхности для данного исследования представлены для диапазонов глубин 0-5, 5-15, 15-25, 25-35, 35-45, 45-55, 55-65 км.

На срезе 0-5 км по скоростям продольных волн четко выделяется разница между северным тектоническим 
(a)
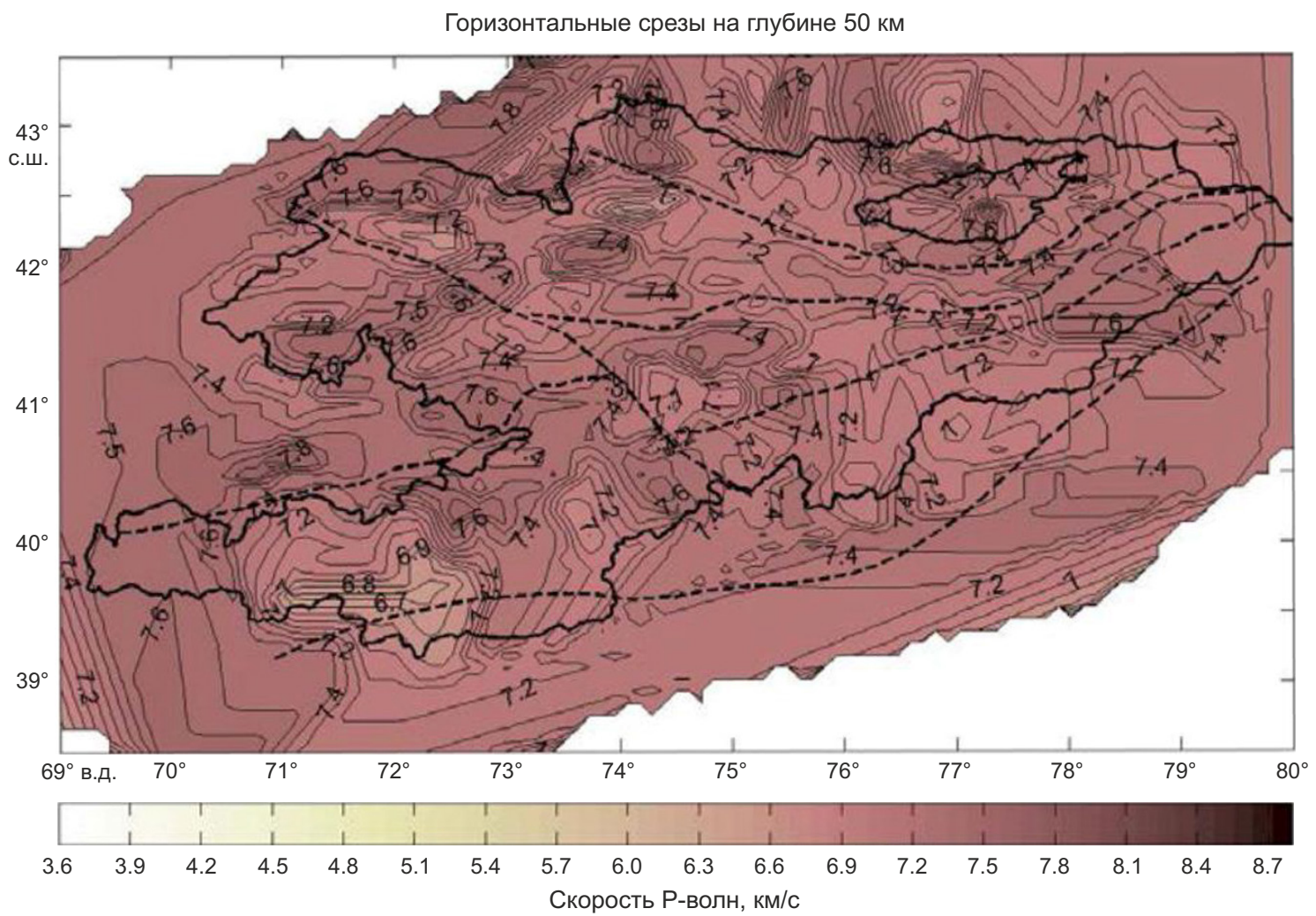

(б)

Горизонтальные срезы на глубине 60 км

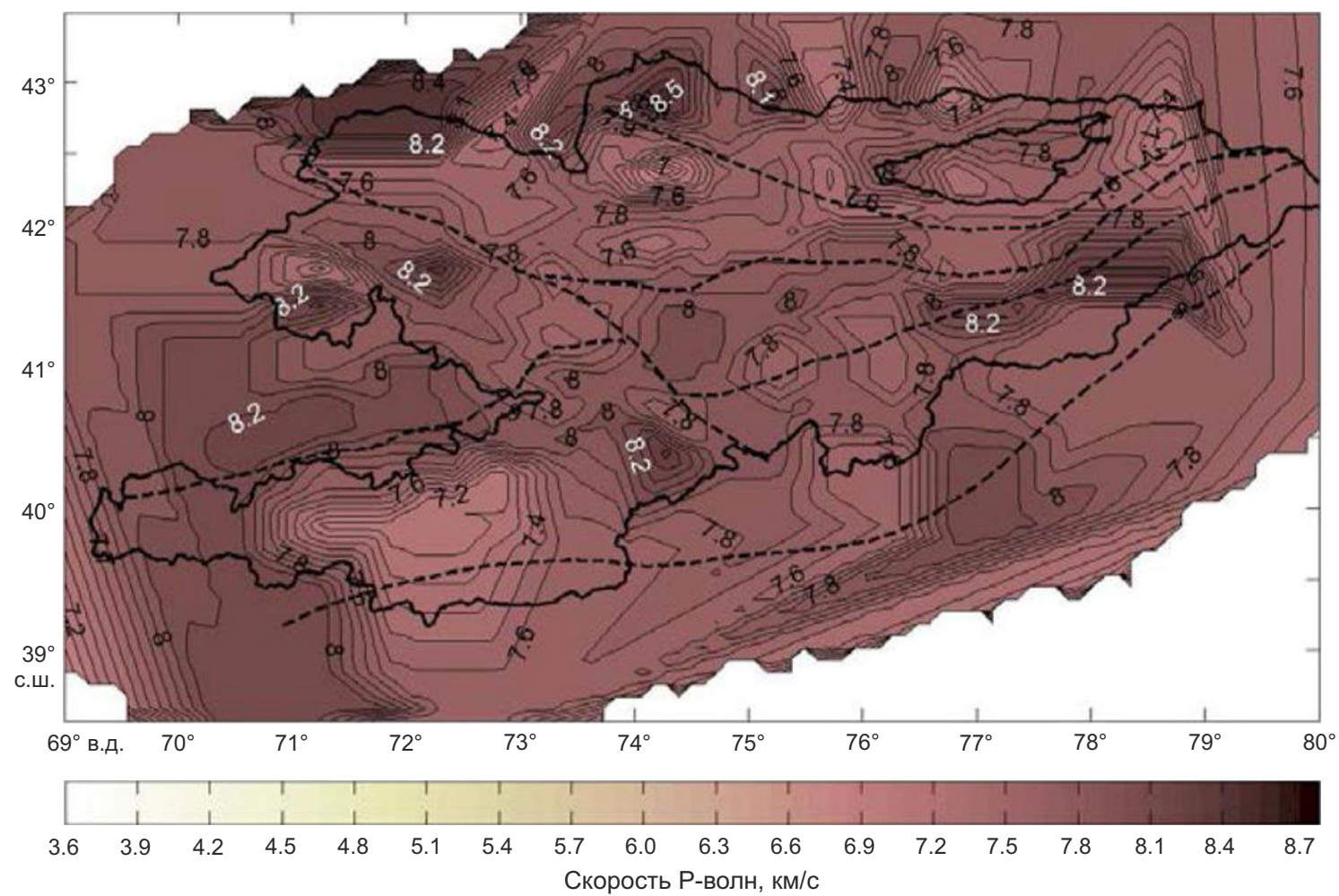

Рис. 5. Горизонтальные скоростные срезы литосферы Центрального Тянь-Шаня на глубине 50 (a) и 60 (б) км (по [Sabitova et al., 2009]). Пунктирными линиями обозначены основные разломные зоны.

Fig. 5. Horizontal seismic wave velocity sections of the lithosphere of the Central Tien Shan for the depths of $50 \mathrm{~km}(a)$ and $60 \mathrm{~km}(6)$ (after [Sabitova et al., 2009]). Dotted lines indicate the major fault zones. 
Горизонтальные срезы на глубине 0 км
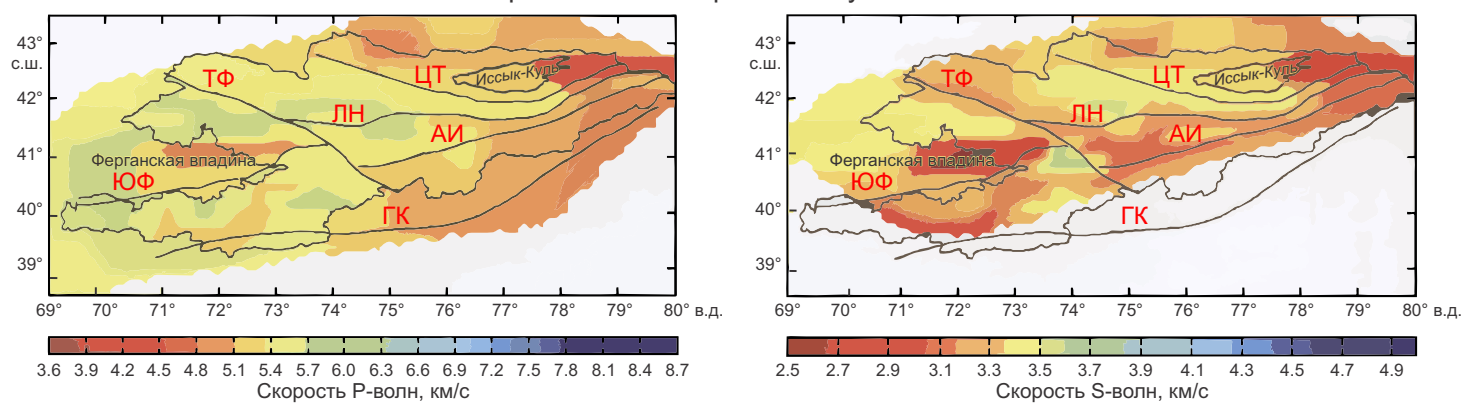

Горизонтальные срезы на глубине 10 км
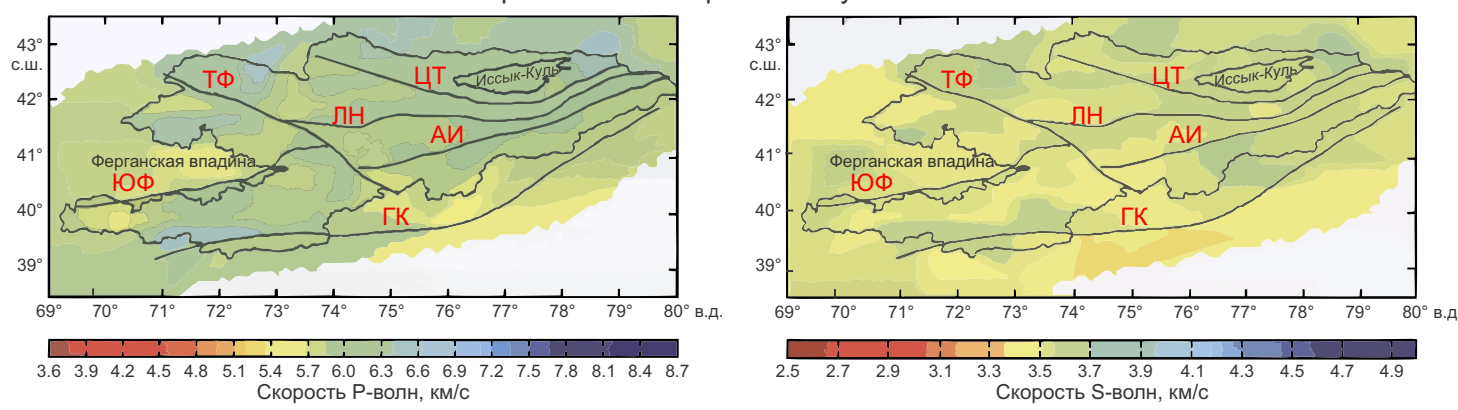

Горизонтальные срезы на глубине 20 км
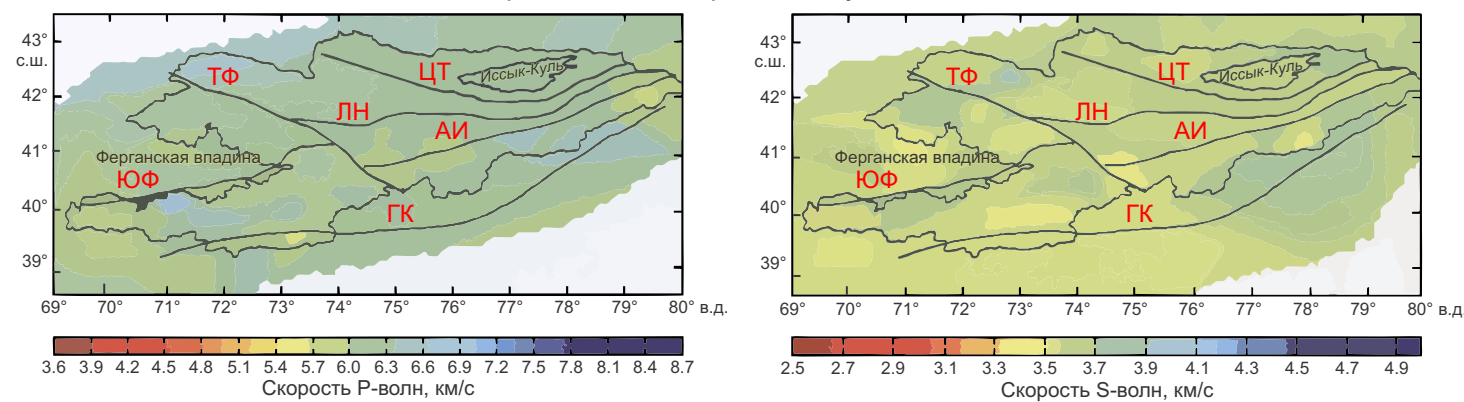

Горизонтальные срезы на глубине 30 км
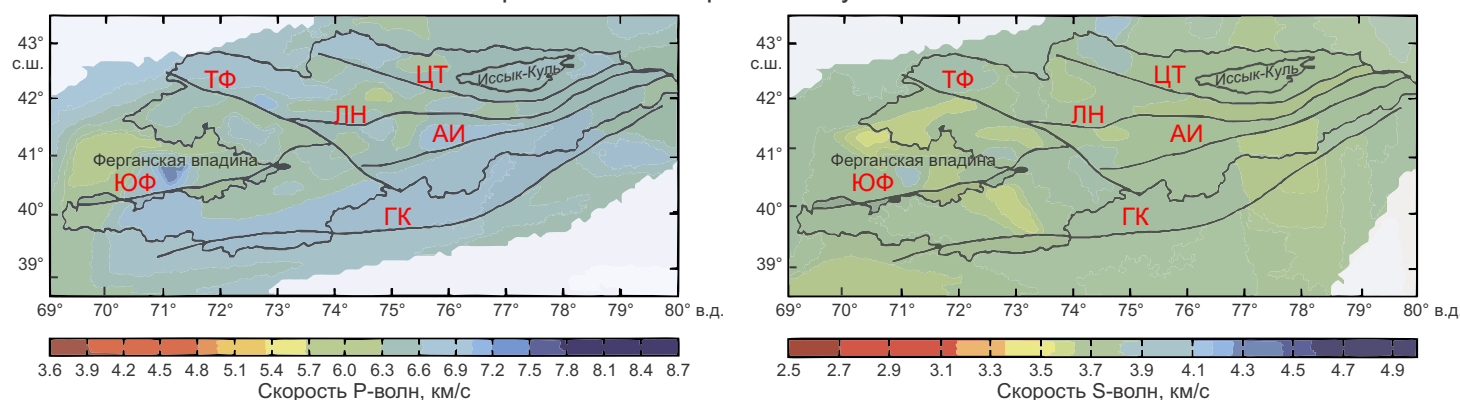

Горизонтальные срезы на глубине 42 км
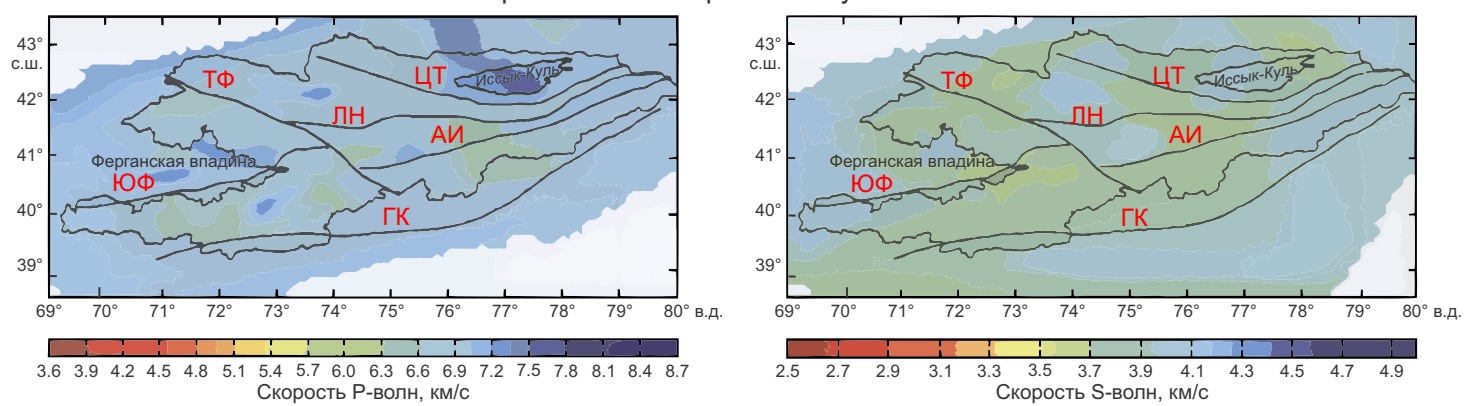

Рис. 6. Распределение скоростей продольных волн (Р) и поперечных (S) для разных глубинных интервалов.

Вынесены следующие крупнейшие разломы: ТФ - Таласо-Ферганский, ЛН - Линия Николаева, ЦТ - Центрально-Терскейский, АИ - Атбаши-Иныльчекский, ГК - Гиссаро-Кокшаальский, ЮФ - Южно-Ферганский [Adamova et al., 2006].

Fig. 6. Distribution of P- and S-wave velocities at different depth intervals.

Major faults: ТФ - Talas-Fergana, ЛН - Nikolaev Line, ЦТ - Central Terskey, АИ - Atbashi-Inylchek, ГК - Gissar-Kokshaal, ЮФ - South Fergana [Adamova et al., 2006]. 
(a)
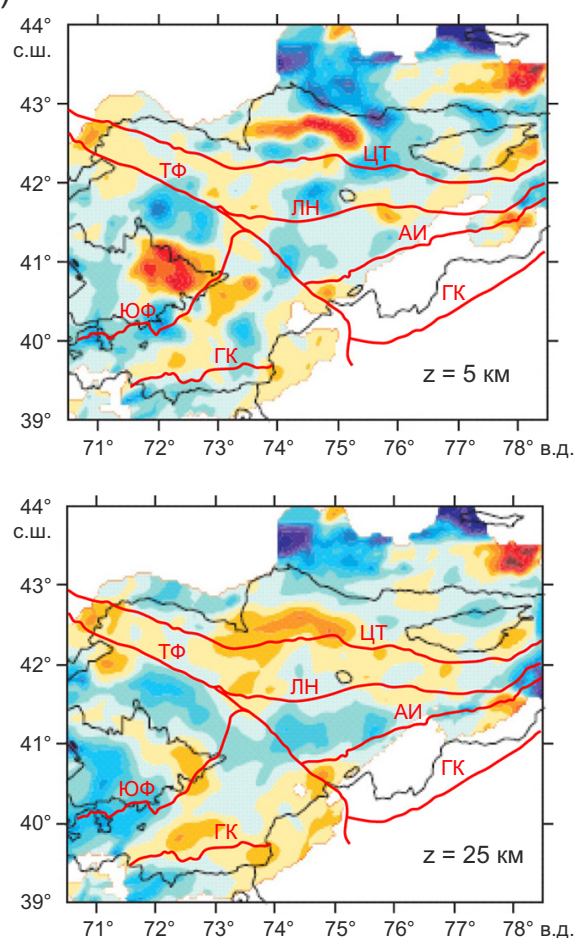

Р-аномалии
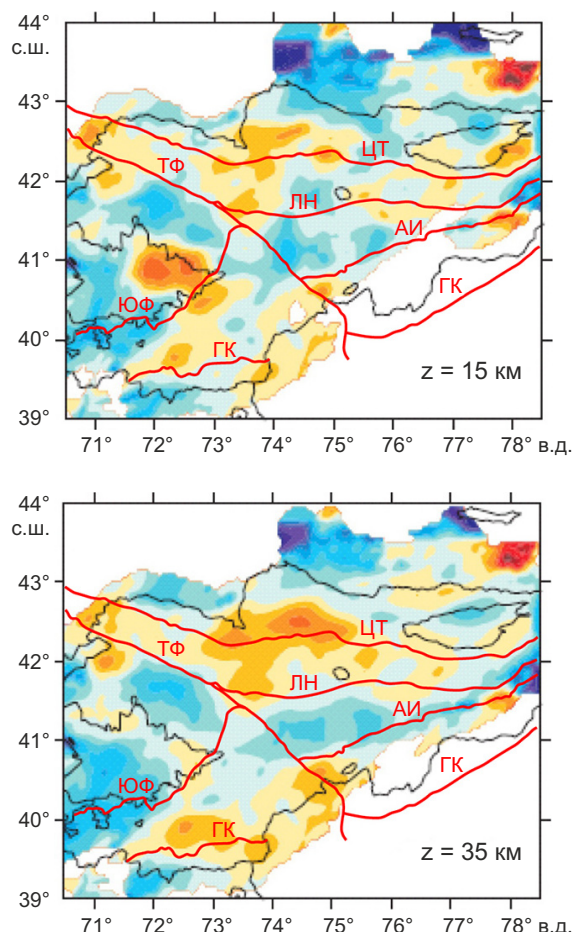

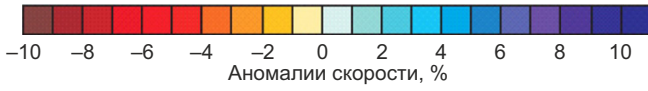

(б)

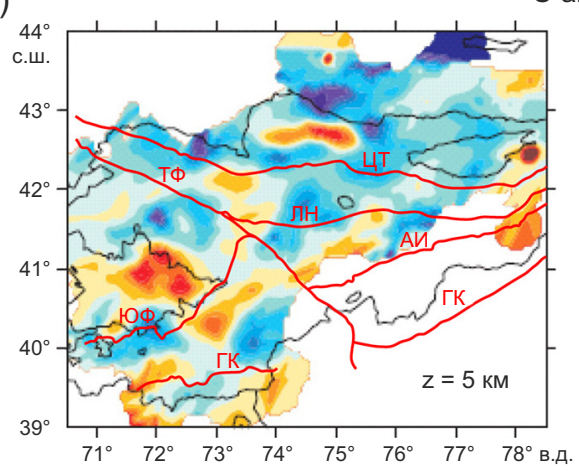

S-аномалии
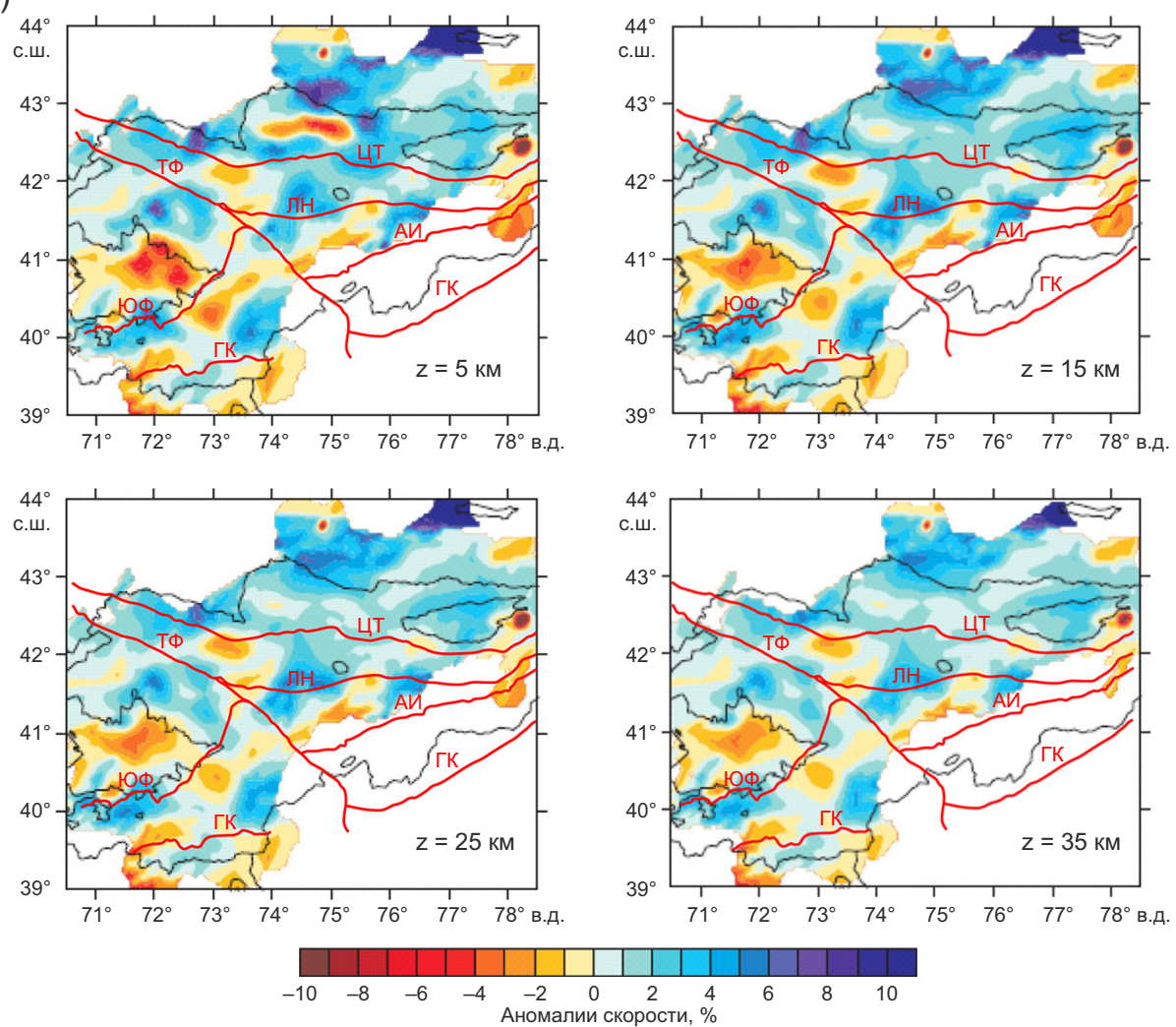

Рис. 7. Распределение аномалий (a) P- и (б) S-скорости на различной глубине [Zabelina et al., 2013].

Красными линиями показаны крупнейшие разломы: ТФ - Таласо-Ферганский, ЛН - Линия Николаева, ЦТ - Центрально-Терскейский, АИ - Атбаши-Иныльчекский, ГК - Гиссаро-Кокшаальский, ЮФ - Южно-Ферганский.

Fig. 7. Distribution of P- and S- wave velocity anomalies ( $a$ and 6 , respectively) at various depths [Zabelina et al., 2013].

Major faults (red lines): ТФ - Talas-Fergana, ЛН - Nikolaev Line, ЦТ - Central Terskey, АИ - Atbashi-Inylchek, ГК - Gissar-Kokshaal, $Ю \Phi$ - South Fergana. 
сегментом Тянь-Шаня (Vp=5.7-6.5 км/с), срединным $(\mathrm{Vp}=5.1-5.6$ км/c) и западным сегментом, отделенным Таласо-Ферганским разломом. В разрезе поперечных волн прослеживается различие в строении между южным и западным сегментами с Vs=2.5-3.1 км/с. По данным сейсмотомографии к зонам низких скоростей можно отнести такие впадины, как Чуйская, Нарынская, Джумгальская, Иссык-Кульская, Аксайская, Сарыджазская. Под Чуйской впадиной выделена зона пониженных значений скорости (Vp=4.6-5.9 км/с) на глубине 0-5 км предгорного района (широтный диапазон 42.5$43.0^{\circ}$ ). Зоны поднятий представлены повышенными значениями объемных волн.

На срезе 5-15 км по продольным волнам не наблюдается значительных разграничивающих структур за исключением южной кромки Южного Тянь-Шаня. Однако это может быть ошибкой, связанной с краевыми эффектами томографической модели. При этом на поверхности Vs низкими значениями выделяется структура к западу от Таласо-Ферганского разлома. Под Киргизским хребтом значения скорости Р-волн в земной коре в слое выше 15 км не превышают 6.2 км/с. Скорости объемных волн становятся ниже по сравнению со слоем 0-5 км. В целом, скорости Р- и S-волн в Северном Тянь-Шане выше скоростей Срединного и Южного.

Слой 15-25 км не позволяет детализировать блочную структуру Тянь-Шаня. Известно, что волноводы распространены на глубинах 15 км [Bagmanova et al., 2014]. Под Киргизским хребтом Vp=6.2-6.4 км/с (под
Чуйской впадиной $\mathrm{Vp}=6.5-7.1$ км/c). Волновод под Алайским хребтом находится на глубине 10-21 км.

Слой 25-35 км показывает отличие зоны Срединного Тянь-Шаня за счет несколько пониженных скоростей продольных волн в данном сегменте. Наиболее существенное их проявление имеет место на глубине от 30 до 40 км на юго-западе и юго-востоке киргизской части Тянь-Шаня, и на глубине 25-35 км под Чуйской впадиной с Vp=5.1-6.1 км/с. Волновод под Чаткальским хребтом занимает интервал глубин 23-29 км. Чуйская впадина характеризуется скоростями $\mathrm{Vp}=6.2-$ 6.6 км/с. Киргизский хребет также отличается понижением скорости - присутствием волновода. При этом в створе с западной частью Чуйской впадины под горами волновод отсутствует (Vp растет до 6.3-6.6 км/c) [Bagmanova et al., 2014].

На глубине 35-50 км аномально низкими скоростями характеризуется южная часть Западного Тянь-Шаня. Разделение на Северный, Срединный и Южный Тянь-Шань не представляется возможным. По поперечным волнам можно выделить скоростную аномалию в Южном Тянь-Шане. Остальная же часть не поддается условному разделению на сегменты. В нижней коре отдельных зон Южного Тянь-Шаня (под хребтами Алай, Ат-Баши, Кок-Шаал) наблюдаются аномально низкие скорости (Vp=5.2-6.2 км/с). Поверхность Мохо погружается от 45 км на севере Киргизии до 60 км в ее центральной части. Встречается существенное повышение скоростей Vp под Киргизским хребтом.

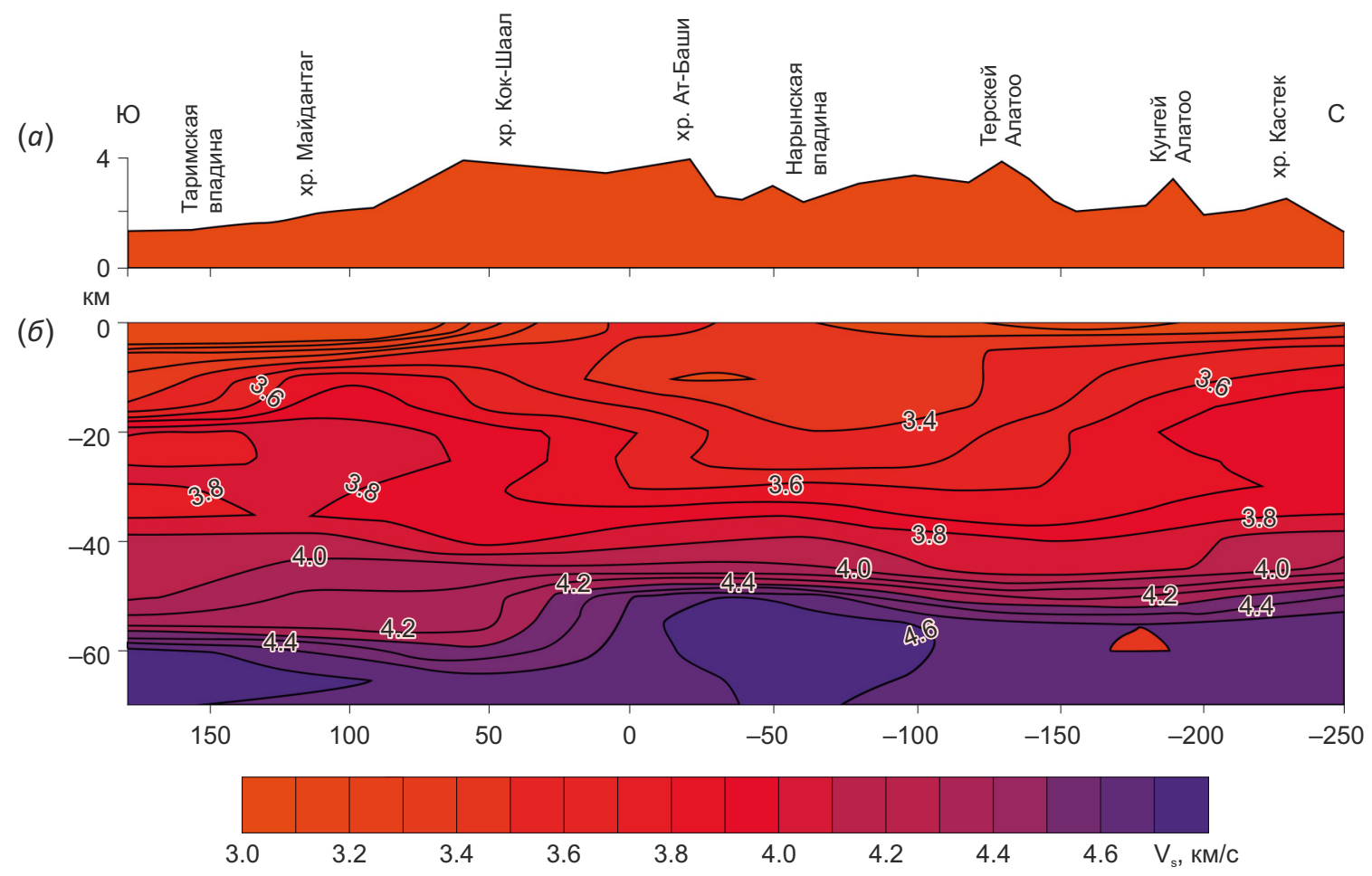

Рис. 8. Разрез скоростей поперечных волн (Vs) для профиля «Нарын» (вдоль $\lambda=76^{\circ}$ ) по [Vinnik et al., 2006]. (a) - рельеф поверхности Земли вдоль профиля; (б) - скоростной (Vp) разрез земной коры и верхней мантии по [Sabitova et al., 2009].

Fig. 8. Section of S-wave velocities (Vs) for the Naryn profile (along $\lambda=76^{\circ}$ ); after [Vinnik et al., 2006]. (a) - relief along the profile; (б) Vp section of the crust and upper mantle after [Sabitova et al., 2009]. 
По значениям продольных волн на глубине 5065 км хорошо прослеживается масштабная сегментация Тянь-Шаня на северный, южный и западный сегменты. По поперечным волнам на той же глубине можно судить только о проявляющейся в разрезе структуре Таласо-Ферганского разлома (к востоку $\mathrm{Vp}=7.0-7.2$ км/с, $\mathrm{Vs}=4.4$ км/с, к западу $-\mathrm{Vp}=7.8-8.0$ км/c, Vs=4.7 км/c). В районе Чуйской впадины наблюдается инверсия скорости - значения скорости $V p=7.5$ км/с здесь являются пониженными относительно скоростей в вышележащем слое (7.8-8.1 км/с). Инверсия скорости в этом слое менее значительна, чем в слое 25-35 км. Повышение скоростей Vр под Киргизским хребтом проявляется частично.

На рис. 7 показано распределение скоростных аномалий на различных глубинах трехмерной скоростной модели, рассчитанной в статье [Zabelina et al., 2013]. Авторы использовали систему наблюдений из 300 сейсмических станций (как аналоговых, так и цифровых сетей KNET, KRNET и др. (см. рис. 2)), действующих в

(a)

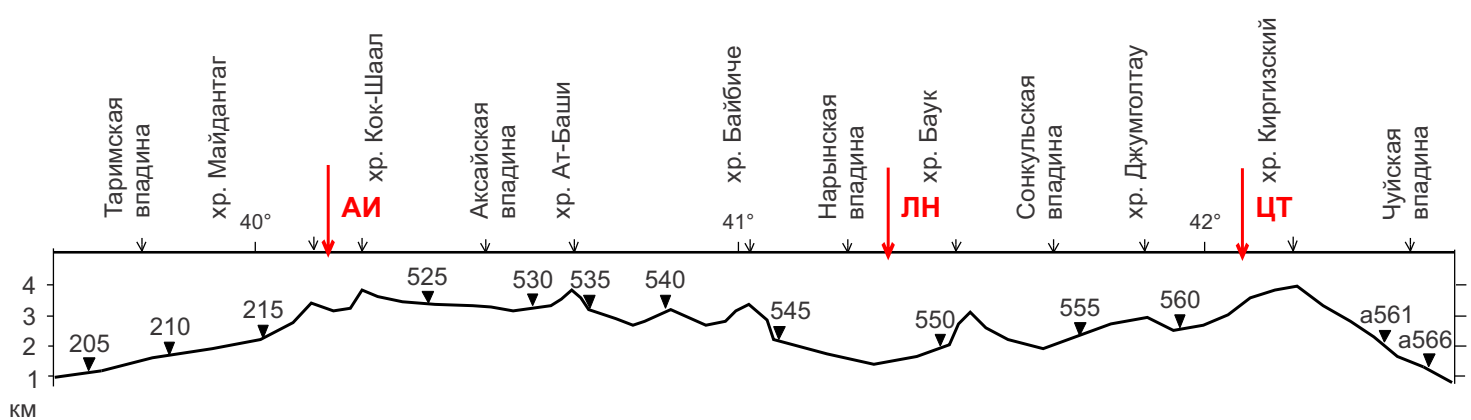

(б)

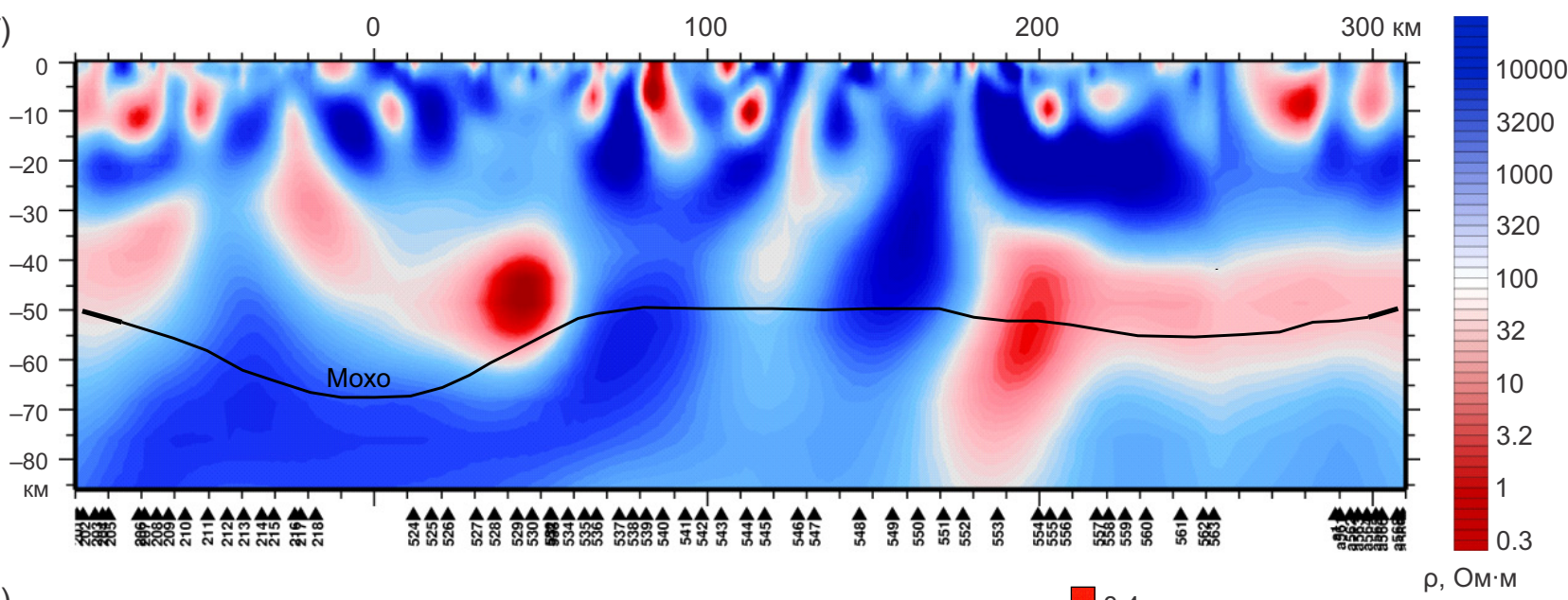

(в)

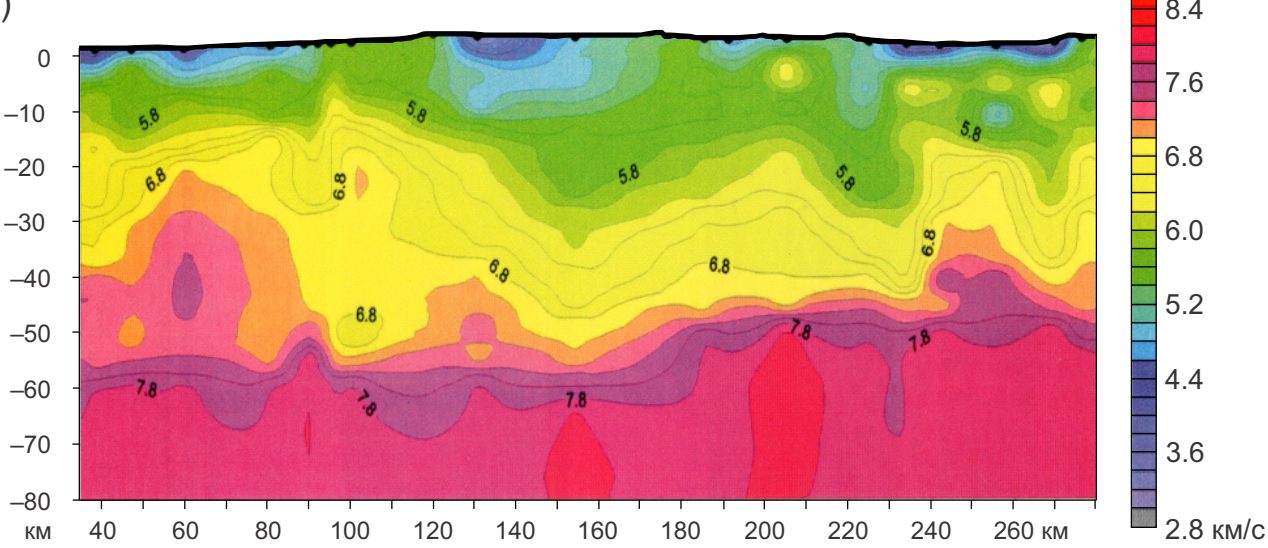

Рис. 9. Профиль «MANAS».

(a) - рельеф и основные геолого-географические объекты вдоль профиля, АИ - Атбаши-Иныльчекский разлом, ЛН - Линия Николаева, ЦТ - Центрально-Терскейский разлом; (б) - геоэлектрический разрез по магнитотеллурическому профилю «MANAS»; (в) - разрез скоростей продольных волн для профиля «MANAS» [Makarov et al., 2010].

Fig. 9. MANAS profile.

(a) - relief and the main geological and geographical features along the profile, АИ - Atbashi-Inylchek fault, ЛН - Nikolaev Line, ЦТ Central Terskey fault; (б) - geoelectric section along the MANAS magnetotelluric profile; ( 8 ) - section of P-wave velocities for the MANAS profile [Makarov et al., 2010]. 
Киргизской Республике и на сопредельных территориях до 2012 г. В работе изучены результаты томографической инверсии (см. рис. 7) на разных пространственно-масштабных уровнях, что позволило рассмотреть структуру литосферы Центрального Тянь-Шаня и получить распределение сейсмических скоростей в земной коре. На основе полученной сейсмотомографической модели авторами статьи [Zabelina et al., 2013] также сделаны выводы о характере коллизии литосферных плит на северной и южной границах Тянь-Шаня погружение с севера на юг Казахстанской плиты под Тянь-Шань до глубины примерно 150 км и Таримской плиты под Тянь-Шань с юга на север.

Согласно сейсмотомографическим моделям, на верхнекоровых срезах (0-5 км, 5-15 км, 15-25 км) отчетливо проявляются крупные впадины Северного ТяньШаня - Чуйская как низкоскоростная и Иссык-Кульская как среднескоростная. Среднескоростными являются и впадины Срединного Тянь-Шаня, такие как Нарынская и Арпинская, а высокоскоростными - впадины Южного Тянь-Шаня - Иныльчекская, Сарыджазская и Аксайская.
Что касается глубин 35-50 км, которые в первой скоростной модели для территории Северного Тянь-Шаня [Roecker et al., 1993] выделялись как протяженные области с аномально низкими скоростными характеристиками (V=5.7-6.1 км/c), то в последующих сейсмотомографических построениях [Adamova, Sabitova, 2001, 2004; Sabitova et al., 2003; и др.] скорости в этом нижнекоровом слое определены не ниже чем 6.2 км/с.

Для территории всего Тянь-Шаня происходит смена характера неоднородностей на глубине 20 км (см. рис. 6, 8; рис. 9). Ниже 20 км более высокие скорости характерны для Западного Тянь-Шаня, а низкие - для Восточного. К западу от Таласо-Ферганского разлома присутствует зона повышенных скоростей, а к востоку - пониженных [Sabitova et al., 2006; Bagmanova et al., 2014; Bagmanova, Mirkin, 2018; и др.].

Впадины имеют отличительную от горных сооружений черту - преимущественно сопровождаются высокоскоростной корой. В целом впадины Северного Тянь-Шаня имеют скорости 5.8-6.7 км/с, Южного - 5.46.0 км/с, а поднятия горных хребтов - 5.3-6.5 км/с. В нижней части земной коры впадины Северного Тянь-Шаня

(a)

(б)
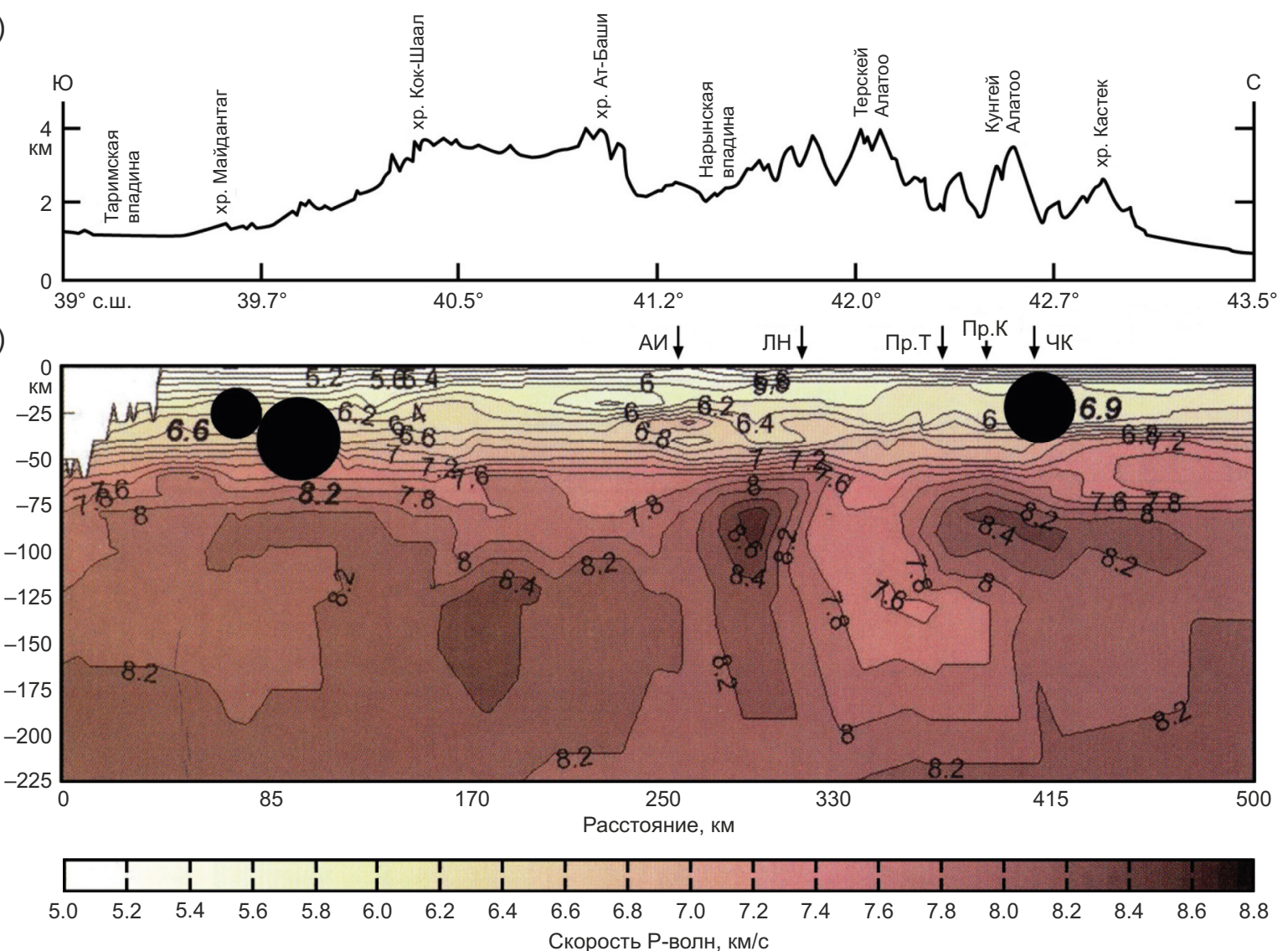

Рис. 10. Меридиональный профиль вдоль $\left(\lambda=76^{\circ}\right)$, совпадающий с геоэлектрическим профилем «Нарын».

(a) - рельеф поверхности Земли вдоль профиля; (б) - скоростной (Vp) разрез земной коры и верхней мантии (по [Sabitova et al., 2009]). Кружки - гипоцентры землетрясений, стрелки - разломы: АИ - Атбаши-Иныльчекский, ЛН - Линия Николаева, Пр.Т Предтерскейский, Пр.К - Предкунгейский; ЧК - Чон-Кеминский [Chedia, 1991].

Fig. 10 Meridional profile along $\lambda=76^{\circ}$, which coincides with the Naryn geoelectric profile.

(a) - relief along the profile; (б) - Vp section of the crust and upper mantle (after [Sabitova et al., 2009]). Circles - earthquake hypocenters, arrows - faults: АИ - Atbashi-Inylchek, ЛН - Nikolaev Line, Пр.T - Pre-Terskey, Пp.К - Pre-Kungey, ЧК - Chon-Kemin [Chedia, 1991]. 
(Илийская, Чу-Сарысуйская, Восточно-Чуйская, ИссыкКульская) характеризуются скоростью 6.6-7.0 км/с, для большей части впадин Южного Тянь-Шаня (Алайская, Таджикская, Таримская) характерны меньшие скорости - 5.8-6.4 км/с. Минимальная скорость зафиксирована для Таримской впадины - 5.7 км/с. Ферганская впадина на этом уровне обладает аномально высокой скоростью - 7.6 км/с.

Скоростные неоднородности верхней части разреза для Тянь-Шаня хорошо согласуются с результатами тектонического районирования данной территории. На рис. 9 неоднородности проявляются в распределении аномалий в виде градиентных зон вблизи основных тектонических структур - разломных зон.

Формирование зон сильных $(M>6.5)$ коровых землетрясений непосредственно связано с особенностями строения мантии и происходящими в ней процессами - очаги большинства сильных землетрясений расположены над краевыми частями низкоскоростных мантийных аномалий, над зонами высоких градиентов скорости, обусловленных контактом разноскоростных литосферных блоков (рис. 10). Объяснением такой сложной скоростной структуры литосферы ТяньШаня с наличием в ней объемов аномально низкоскоростной мантии субвертикального заложения (см. рис. $5,6,7)$, по мнению ряда авторов, является проявление процессов плюм-тектоники [Knauf et al., 1980; Vinnik, 1998; Grachev, 1999; Pogrebnoi, Sabitova, 2001; Khain, 2002; Nusipov et al., 2005; Sabitova et al., 2006].

\section{4. РЕЗУЛЬТАТЫ МАГНИТОТЕЛЛУРИЧЕСКОГО ЗОНДИРОВАНИЯ}

О региональной расслоенности Центрального ТяньШаня свидетельствует не только характер распределения скоростных неоднородностей, но и результаты глубинных магнитотеллурических зондирований

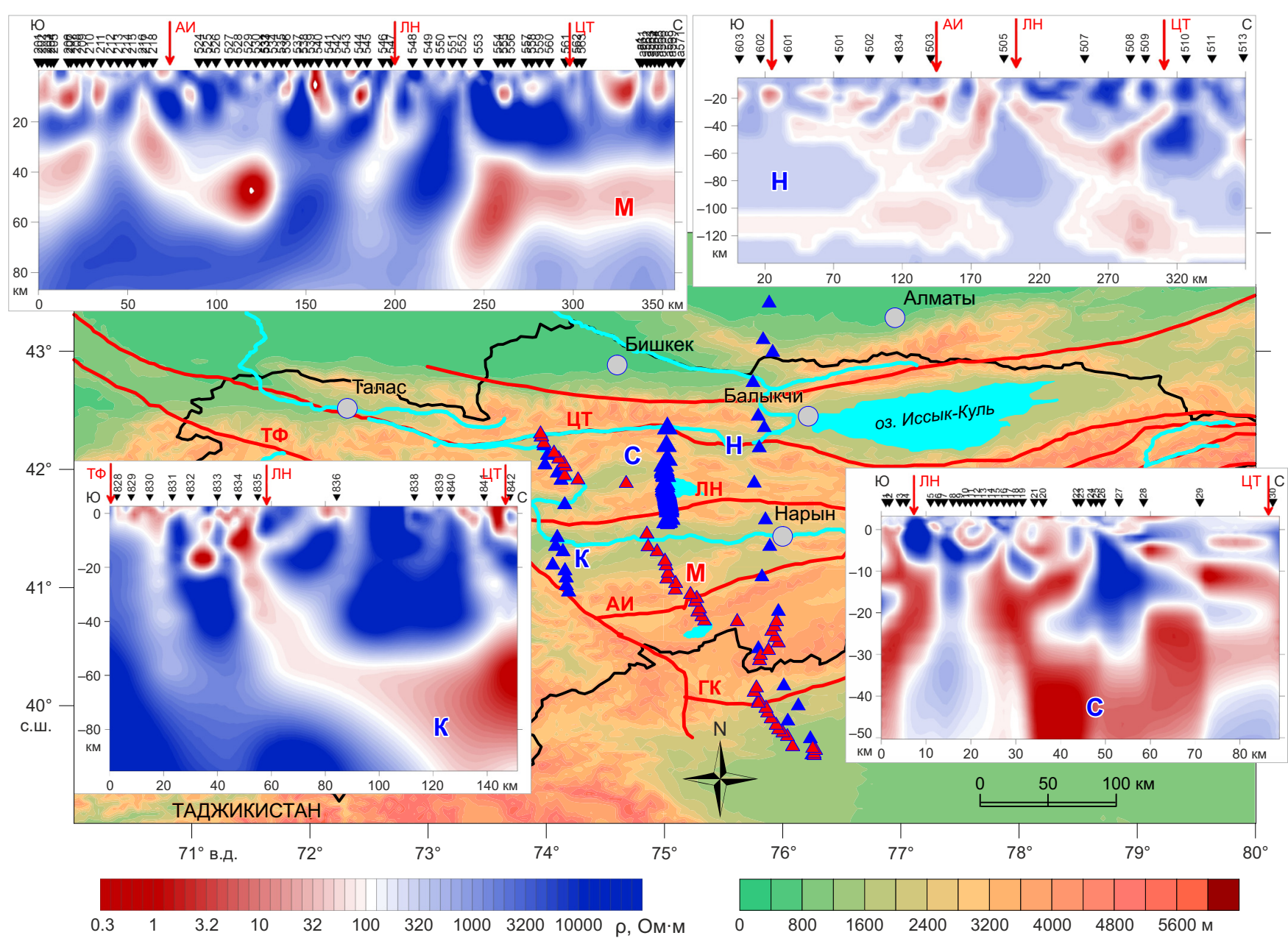

Рис. 11. Результаты глубинных магнитотеллурических зондирований по серии региональных профилей Центрального Тянь-Шаня.

Синими треугольниками обозначены меридиональные профили: Н - Нарын, С - Сон-Куль, К - Кокемерен; красными: профиль М - «MANAS». Красными линиями обозначены крупнейшие разломы (см. рис. 6): ТФ - Таласо-Ферганский, ЛН - Линия Николаева, ЦТ - Центрально-Терскейский, АИ - Атбаши-Иныльчекский, ГК - Гиссаро-Кокшаальский.

Fig. 11. Deep magnetotelluric sounding results from a series of the regional profiles of the Central Tien Shan.

Meridional profiles marked by blue triangles: $\mathrm{H}$ - Naryn, C - Son-Kul, K - Kokemeren; red triangles: MANAS profile. Major faults (red lines and letters, see Fig. 6): ТФ - Talas-Fergana, ЛН - Nikolaev Line, ЦТ - Central Terskey; АИ - Atbashi-Inylchek, ГК - Gissar-Kokshaal. 
(рис. 11, 12). Результаты геоэлектрических построений демонстрируют наличие субгоризонтальных проводящих слоев на различных пространственно-масштабных уровнях, за исключением, пожалуй, верхних частей геоэлектрических разрезов (до глубины 10 км), где присутствуют субвертикальные структуры и границы, отражающие структуру распределения неоднородностей в земной коре [Rybin et al., 2001]. Анализ соотношения скоростей Vp/Vs в сейсморазведке обычно используется для выявления флюидонасыщенных зон, в связи с чем может быть интересным поведение этого параметра и характер распределения проводящих структур в геоэлектрической модели. На сейсмических разрезах положительные аномалии Vp/Vs выделяют зоны концентрации флюидов в залежах углеводородов или обводненных пластах. Для условий средней и нижней коры, согласно работам [Letnikov, 2003, 2006], его экстремумы показывают состояние с повышенной температурой и флюидонасыщенностью. При наличии экстремумов около поверхности, например в районе Африканских рифтов, фиксируется геодинамическая неустойчивость среды.

Сопоставление распределения скоростных неоднородностей в объемной сейсмотомографической модели с геологической и тектонической картами показало, что литосфера современного Тянь-Шаня характеризуется раздробленностью. Данные сейсмической томографии свидетельствуют о том, что верхняя часть

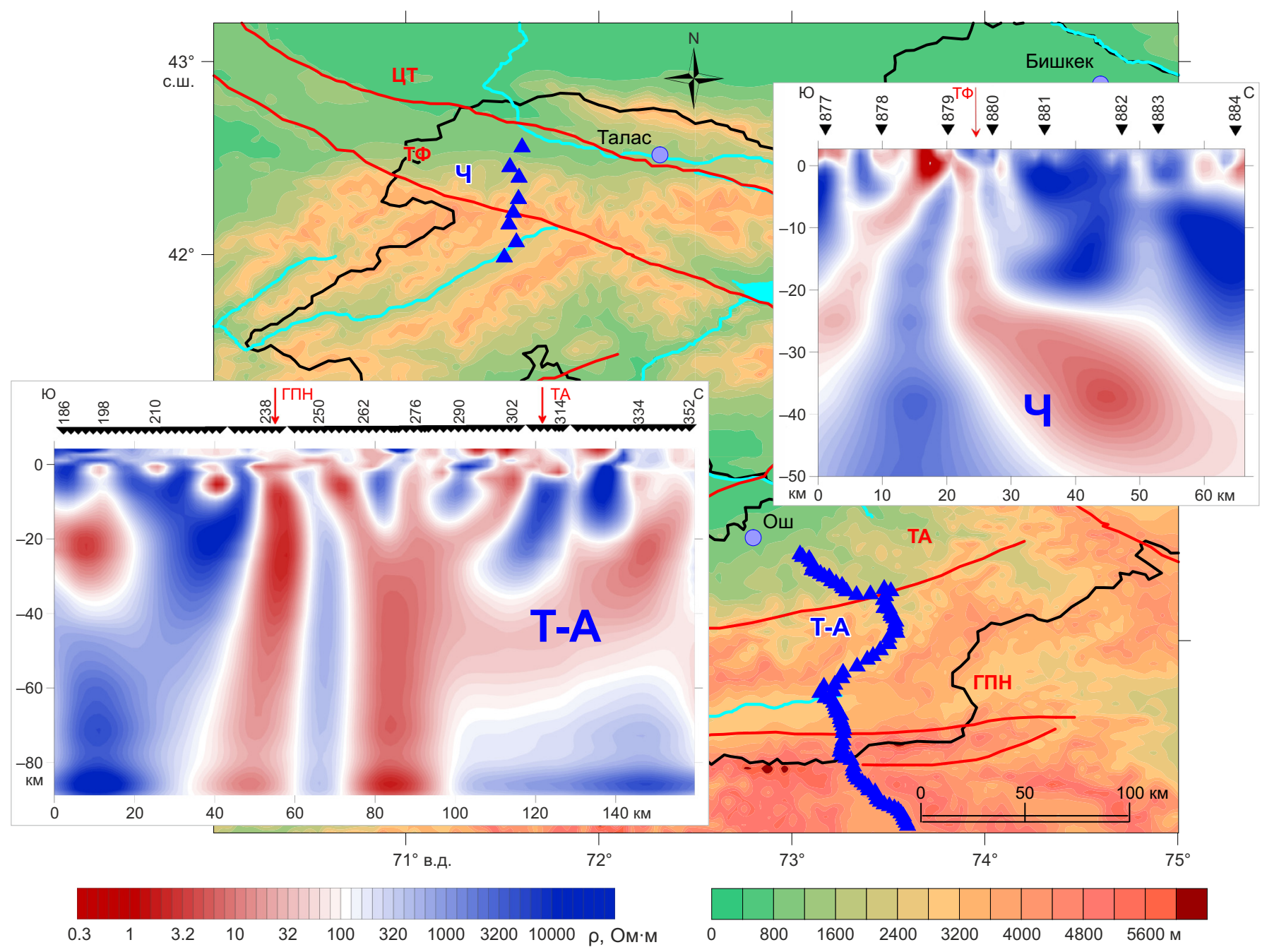

Рис. 12. Результаты глубинных магнитотеллурических зондирований Западного Тянь-Шаня в зонах Таласо-Ферганского разлома и сочленения Памира и Тянь-Шаня.

Синими треугольниками обозначены профили: Ч - Чаткал, Т-A - Tipage-Alai, отрезок на территории Алайской впадины (Alai) в рамках проекта "Tien Shan - Pamir Geodynamic Program" (TIPAGE). Красными линиями и буквами показаны крупнейшие разломы: ЦТ - Центрально-Терскейский, ТФ - Таласо-Ферганский, ТА - Трансалайский, ГПН - Главный памирский надвиг.

Fig. 12. Deep magnetotelluric sounding results for the Western Tien Shan (Talas-Fergana fault zone, and the Pamir-Tien Shan junction zone).

Profiles (marked by blue triangles): Ч - Chatkal, T-A - Tipage-Alai (this section in the Alai basin was constructed under the Tien Shan Pamir Geodynamic Program, TIPAGE). Major faults (red lines and letters): ЦT - Central Terskey, TФ - Talas-Fergana, TA - Trans-Alai, ГПН - Main Pamir thrust. 
земной коры Тянь-Шаня разбита на отдельные литосферные блоки, одним из которых является Ферганский блок (см. рис. 1).

Данный блок испытывал вращение против часовой стрелки, образуя при этом типичную вихревую структуру. С учетом того, что вещество между блоками земной коры и литосферной мантии может быть разуплотнено, нагрето и частично расплавлено, такие объекты могут очень хорошо отражаться в геоэлектрических моделях [Bataleva, 2005; Bataleva et al., 2006].

Общим для рассматриваемых тектонических сегментов является то, что наиболее ярко выраженные проводящие объекты геоэлектрических моделей, построенных по результатам магнитотеллурических зондирований [Batalev et al., 1989, 1993, 2013; Bielinski et al., 2003; Bataleva et al., 2006, 2013; Berdichevsky et al., 2010; Makarov et al., 2010; Rybin et al., 2008; Rybin, 2011; Trapeznikov et al., 1997], совпадают с низкодобротными зонами [Aptikaeva, 2018; Aptikaeva et al., 1996]. Это может свидетельствовать о флюидонасыщении выявленных проводников и волноводов литосферы Тянь-Шаня, поскольку низкоскоростные аномалии Р-волн также соответствуют зонам низкой добротности. Сильнейшие землетрясения Тянь-Шаня приурочены к границам блоков и ослабленных зон, которые, как правило, являются зонами максимального контраста поглощения. Структура поля поглощения коррелирует с тектоническим строением района; в частности, ослабленные зоны соответствуют зонам разломов [Aptikaeva, 2018; Aptikaeva et al., 1996]. Анализ положения гипоцентров сейсмических событий и распределения скоростных неоднородностей в земной коре позволяет сделать вывод о приуроченности землетрясений к высокоградиентным зонам геоэлектрических моделей [Rybin, 2011].

Очень часто эти структуры выполаживаются и имеют характерную для областей внутриконтинентального сжатия форму листрических разломов. Выполаживание, как правило, происходит на границах зон с аномальными физическими свойствами - электропроводностью или скоростными характеристиками среды [Bataleva, Batalev, 2015a, 2015b].

Наиболее сложная картина чередования резко дифференцированных по проводимости субвертикальных структур, достигающих своими корнями глубины подошвы нижней коры и верхней мантии, наблюдается в центральной части МТЗ профилей (см. рис. 11) вдоль меридианов $74^{\circ}$ (профиль Кокемерен) и $76^{\circ}$ (профиль «Нарын») [Bielinski et al., 2003; Rybin et al., 2009; Makarov et al., 2010; Batalev et al., 2011; Bataleva, 2005; Bataleva et al., 2006; Bataleva, Batalev, 2014b]. Сопоставление скоростных аномалий в сейсмотомографических срезах и объектов аномально низкого электрического сопротивления в геоэлектрических разрезах земной коры свидетельствует: 1) об их приуроченности к разломным структурам, 2) о листрической форме глубинных разломов, 3) о выполаживании разломов на глубине 1020 км и глубине залегания кровли корового проводящего слоя, 4) о существовании в указанных интервалах земной коры зон повышенной трещиноватости или пластичности, 5) о совпадении волноводов и зон повышенной проводимости.

Исследования земной коры Западного Тянь-Шаня (Памиро-Тяньшаньская область) также показали ее многослойно-неоднородное по разрезу и блоковое в плане глубинное строение (рис. 12). По многочисленным результатам подтверждается 3-этажное строение за счет вещественно-структурной и скоростных латеральных и вертикальных неоднородностей [Matyukov et al., 2014; Sass et al., 2014; Schneider et al., 2013; Rybin et al., 2019].

Модель двумерной инверсии вдоль профиля «MANAS» с учетом рельефа представлена в работе [Rybin, 2011], в которой показано, что геоэлектрическая модель выглядит наиболее информативно при сравнении с сейсмическим разрезом, построенным по данным методов МОВ-ОГТ и сейсмотомографии [Makarov et al., 2010]. Комплексная интерпретация результатов сейсморазведки и данных МТЗ позволяет сделать следующие выводы об основных структурных элементах глубинного разреза земной коры вдоль геотраверса (см. рис. 11). Особенности распределения геоэлектрических неоднородностей в разрезе земной коры хорошо коррелируют с неотектоническими структурами. Верхняя часть разреза осложнена наличием проводящих зон с сопротивлением 10-100 Ом•м, которые имеют хорошую сходимость с геолого-структурными построениями. Так, например, показанные в геологическом разрезе Нарынской впадины «скрытые» разломные структуры фундамента в геоэлектрической модели отображены наклонными и субвертикальными проводящими объектами шириной до 1.5-2.0 км. Строение Таримской платформы близко к одномерному, что подверждается сейсмическими данными, удельное электрическое сопротивление горных пород меняется в пределах 1001000 Ом•м [Batalev, Bataleva, 2013]. В геоэлектрическом разрезе, как и на сейсмической модели, проявляется зона сочленения Таримской платформы и Южного ТяньШаня, обусловленная пододвиганием плиты под ТяньШань вдоль пологого (около $30-35^{\circ}$ ) регионального разлома [Makarov et al., 2010], который прослеживается до подошвы земной коры и глубже под всей системой поднятий Кокшаальского хребта.

Особое внимание в геолектрической модели профиля MANAS привлекает субвертикальная область низкого сопротивления (0.1-10.0 Ом·м) под пунктами 541544 в районе хребта Байбиче (см. рис. 9, 11, профиль «MANAS»), глубина залегания которой достигает 80 км, аналогичная зона выделена по данным сейсмического зондирования.

В соответствии с данными МОВ-ОГТ [Makarov et al., 2010; Rybin, 2010; Rybin et al., 2009] среднекоровый слой К1-К2, построенный по профилю вдоль 76-го меридиана в.д. (см. рис. 8), отличается высокой степенью «мутности» и хорошо коррелирует с волноводом, выявленным по результатам более ранних глубинных построений для Тянь-Шаня. В геоэлектрической модели, построенной вдоль этого профиля «Нарын» (см. 
рис. 11), спорадически проявляется верхнекоровый проводник, кровля которого расположена на глубине порядка 10 км [Rybin, 2011]. Поведение этого слоя не противоречит существующей сегментации литосферы Тянь-Шаня и по своему характеру существенно различается под Южным и Северным Тянь-Шанем. Для Таримской платформы на глубине порядка 25-30 км он с резким разделом подстилает слой консолидированной верхней коры. В зоне поддвига под Тянь-Шань слой наклоняется более круто и прослеживается до глубины 65 км, до границы, отождествляемой с подошвой земной коры. Под Тянь-Шанем слой К1-К2 залегает существенно выше - на глубине 10-18 км (в этом же диапазоне глубин, очень слабо поднимаясь в южном направлении, он может быть прослежен и на разрезе МОВЗ в виде прерывистой зоны пониженных скоростей, до Vp=5.06.0 км/c). На северном отрезке профиля, под поднятиями Молдотау-Терскейской системы и зоной ее сочленения с Нарынской впадиной, он подобен вышеописанному, но существенно иначе представлен на всем остальном пространстве. Здесь он отличается преимущественно малой и неустойчивой мощностью ( 1.52.5 км), изменчивостью уровня залегания. Это особенно характерно для Аксай-Кокшаальского отрезка профиля. В общем, достаточно отчетливые (контрастные) нижняя и верхняя границы этого слоя под Аксайской впадиной и поднятиями Кок-Шаал отличаются некоторой изрезанностью, «заливами», уходящими в смежные более интенсивно отражающие слои. Такое строение слоя К1-К2, кулисный характер сопряжения его со смежными слоями позволяют предполагать, что в его обособлении и структуре существенную роль имели и имеют процессы тектонического расслоения, разупрочнения и разуплотнения земной коры, ее дислокации со срывами и смещениями вдоль субгоризонтальных поверхностей. Это расслоение, срывы и смещения согласуются с дислокациями земной коры Тянь-Шаня, что обусловлено пододвиганием под него коры Таримского массива.

При сопоставлении региональных геоэлектрических профилей, выполненных для территории ТяньШаня с начала 80-х годов прошлого столетия по настоящий момент, можно выделить некоторые закономерности в распределении электрических характеристик земной коры как в субширотном направлении, так и по отношению к зоне Таласо-Ферганского разлома. Основные черты геоэлектрической модели Центрального Тянь-Шаня можно охарактеризовать следующим образом: 1) высокая степень неоднородности верхней части геоэлектрического разреза земной коры; 2) существование зон пониженного электрического сопротивления, пространственно приуроченных к зонам динамического влияния основных разломных структур; 3) наличие слоев аномально высокой электропроводности - в пределах земной коры (коровый проводящий слой) и на астеносферных глубинах.

По результатам проведенных на сегодняшний день магнитотеллурических исследований обнаружены объекты с аномально высокой электропроводностью в земной коре и верхней мантии, приуроченные к границам крупных тектонических элементов, которые обозначены на геолого-тектонических картах. В верхней части геоэлектрического разреза (от 10 м до глубины в десятки километров) они представлюют собой субвертикальные или наклонные проводящие зоны, которые очень хорошо коррелируют с зонами динамического влияния крупнейших тектонических нарушений Тянь-Шаня - Линией Николаева, Атбаши-Иныльчекским, Таласо-Ферганским разломами [Batalev et al., 1993, 2013; Trapeznikov et al., 1997; Batalev, 2002; Rybin, 2001, 2011; Bataleva, 2005; Bataleva et al., 2011a, 2011b]. На большей части протяженности разломных структур, выделенных по магнитотеллурическим данным, прослеживается связь с коровым проводящим слоем (рис. 13). Впервые слой повышенной электропроводности, залегающий на глубине 35-45 км, в земной коре Северного Тянь-Шаня был установлен при интерпретации результатов профильных магнитотеллурических зондирований, выполненных в Чуйской впадине [Batalev et al., 1989].

Коровый проводящий слой спорадически развит на всей изученной территории Тянь-Шаня, его суммарная проводимость возрастает с севера на юг, глубина залегания кровли в том же направлении уменьшается. Анализ характеристик корового проводящего слоя позволяет разделить рассматриваемую территорию на четыре зоны субширотного простирания (рис. 13, 14).

Первая зона (зона I) на севере включает в себя южную окраину Казахского щита и Муюнкумо-Наратский жесткий массив, а ее южной границей можно считать систему разломов Северо-Тяньшаньской разломной зоны (Аксуйский, Чонкурчакский, Байтикский, Аламединский, Иссыкатинский, Шамсинский, Северо-Кеминский и Южно-Кеминский). Кровля корового проводящего слоя находится на глубине 30-45 км, его продольная проводимость оценивается в 300-400 См.

Вторая зона (зона II) электропроводности ограничена с юга системой глубинных разломов Линии Николаева. Характерной особенностью этой зоны является скачкообразное увеличение интегральной электропроводности корового проводника до 1200 См на севере зоны и подъем кровли до глубины 25 км. При приближении к важнейшей линии Тянь-Шаня (Линии Николаева) электропроводность нижнекорового проводника достигает значений $1500 \mathrm{CM}$, а глубина до его кровли местами уменьшается до 15-20 км. Вышеописанные две зоны входят в структурно-формационную область Северного Тянь-Шаня.

Третья зона (зона III) находится в пределах Срединного Тянь-Шаня, т.е. в области распространения каледонско-герцинской складчатости. Характерной особенностью геоэлектрического разреза земной коры этой зоны является его сложность и контрастность электрических свойств среды на всех пространственно-масштабных уровнях. Что касается интегральной проводимости корового слоя, то здесь она достигает максимума - 2000 См, глубина залегания его кровли 


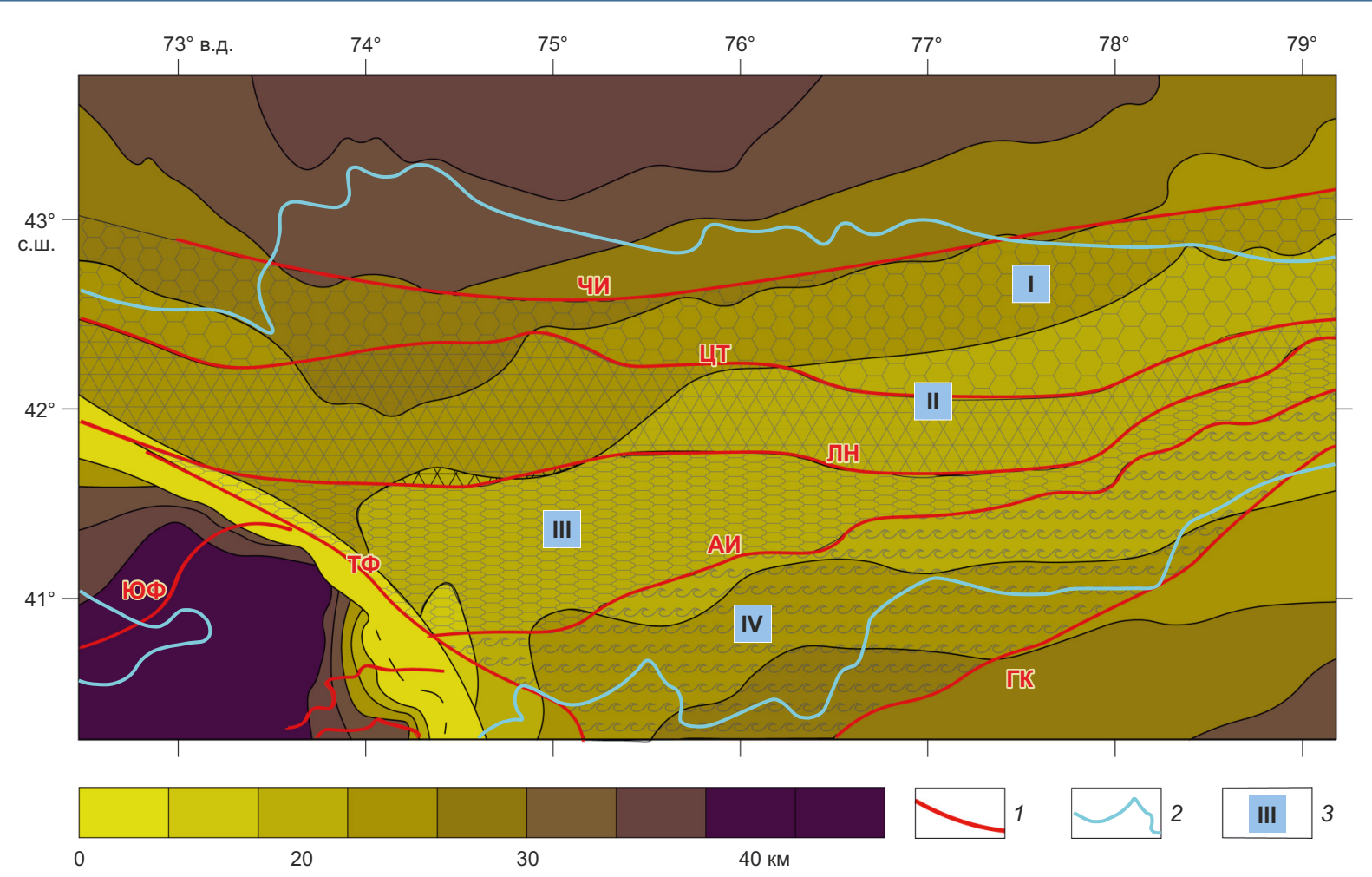

Рис. 13. Карта глубины кровли залегания корового слоя для территории Тянь-Шаня.

1 - крупнейшие разломы: ЧИ - Чу-Илийский, ТФ - Таласо-Ферганский, ЛН - Линия Николаева, ЦТ - Центрально-Терскейский, АИ - Атбаши-Иныльчекский, ГК - Гиссаро-Кокшаальский, ЮФ - Южно-Ферганский; 2 - границы Киргизской Республики; 3 геоэлектрическое зонирование Центрального Тянь-Шаня (описание зон I-IV в тексте).

Fig. 13. Crustal depth map of the Tien Shan.

1 - major faults: ЧИ - Chu-Ily, ТФ - Talas-Fergana, ЛН - Nikolaev Line, ЦТ - Central Terskey, АИ - Atbashi-Inylchek, ГК - Gissar-Kokshaal; 2 - state borders of the Kyrgyz Republic; 3 - geoelectric zoning of the Central Tien Shan (zones I-IV are described in the text).

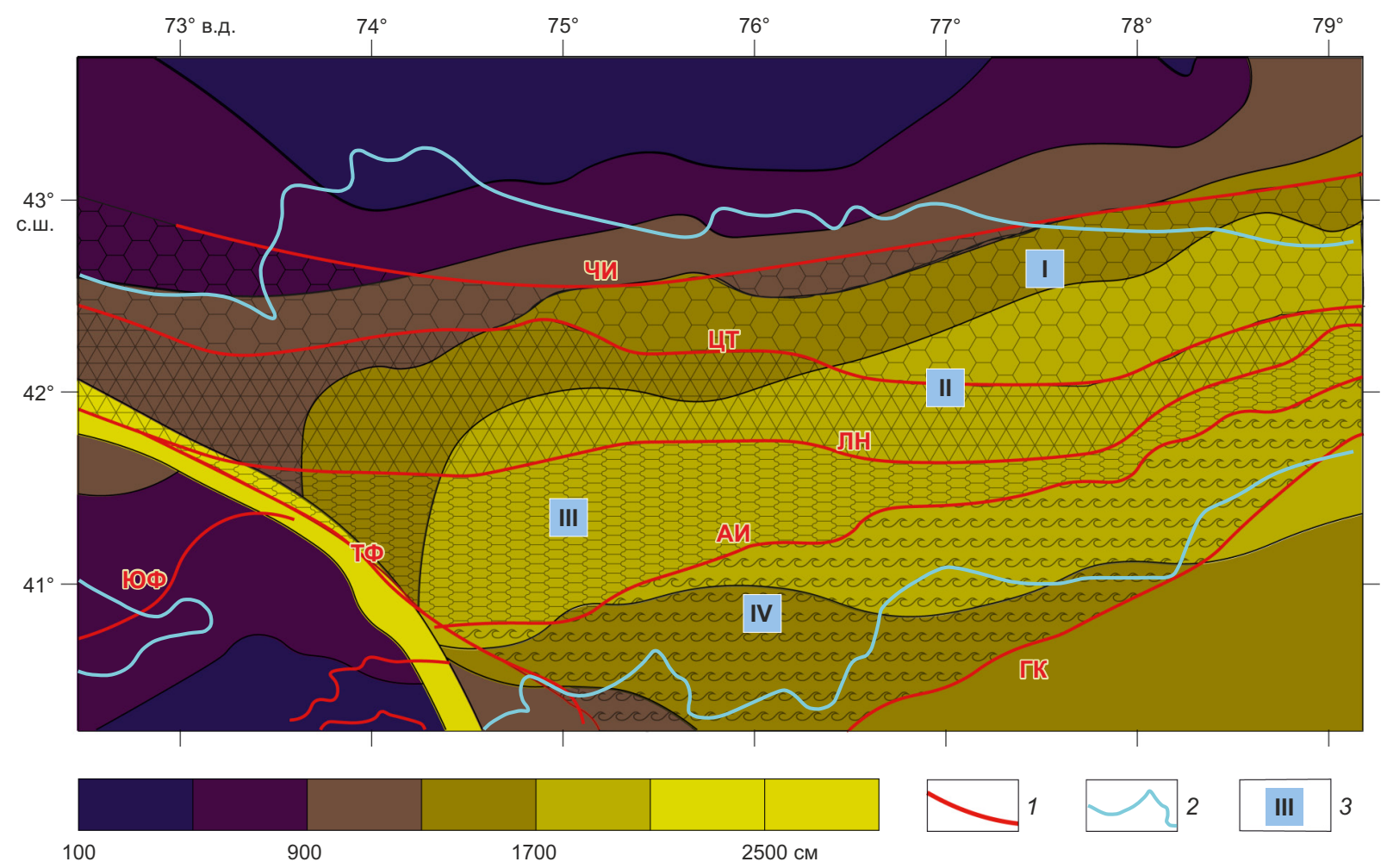

Рис. 14. Карта проводимости для территории Тянь-Шаня. Условные обозначения см. на рис. 13, описание зон I-IV - в тексте.

Fig. 14. Electrical conductivity map of the Tien Shan. See the legend to Fig. 13. Zones I-IV are described in the text. 
становится 15-20 км, что позволяет считать его среднекоровым. Наименьшая глубина до поверхности зафиксирована в районе Нарынской впадины (15 км).

Для территории Южного Тянь-Шаня, что соответствует зоне IV (см. рис. 13; рис. 14), северной границей которого служит зона Атбаши-Иныльчекского разлома, слой приближается к дневной поверхности до глубины порядка 25-20 км, а его электропроводность несколько понижается и достигает $1500 \mathrm{Cm}$.

Особое место в структуре корового проводящего слоя занимает зона Таласо-Ферганского разлома, к которой приурочена аномалия электропроводности [Bataleva, 2005; Bataleva et al., 2005, 2006, 2013; Batalev et al., 2013].

Верхняя часть земной коры, ограниченная снизу проводящим слоем, имеет блоковую структуру, осложненную разломами, которые характеризуются значительной зоной динамического влияния, различной протяженности и глубины заложения, зачастую листрической формы. Зоны разломов сложены проводящими породами, сопротивление которых варьируется в пределах от 10-15 до 50-70 Ом•м. Выполаживание разломов наблюдается на определенной глубине порядка 10-12 и 17-20 км, что свидетельствует о существовании в данном интервале верхней и средней коры ослабленных зон. На глубине нижней коры для всей территории Тянь-Шаня также наблюдаются круто наклоненные проводящие структуры, которые приурочены к разломам и переходят в субгоризонтальный коровый проводящий слой. По трем геотраверсам, секущим Центральный Тянь-Шань, и серии профилей, заложенных вкрест Таласо-Ферганского разлома, подтверждается региональное распространение проводящего слоя в низах коры и наличие проводника на астеносферной глубине.

По результатам анализа геоэлектрических моделей, построенных по трем геотраверсам, секущим Центральный Тянь-Шань (см. рис. 11), можно сделать выводы о соответствии древней сутурной зоны Линии Николаева, которая представлена серией субвертикальных проводящих структур северной вергентности, границе между Северным и Средним Тянь-Шанем. Эти структуры в плане представлены листрическими разломами, идущими от земной поверхности почти вертикально до глубины средней коры и глубже, где они выполаживаются и переходят в субгоризонтальные проводники.

Суммарная проводимость $(\mathrm{S})$ корового проводящего слоя Северного Тянь-Шаня (рис. 15), представляющего
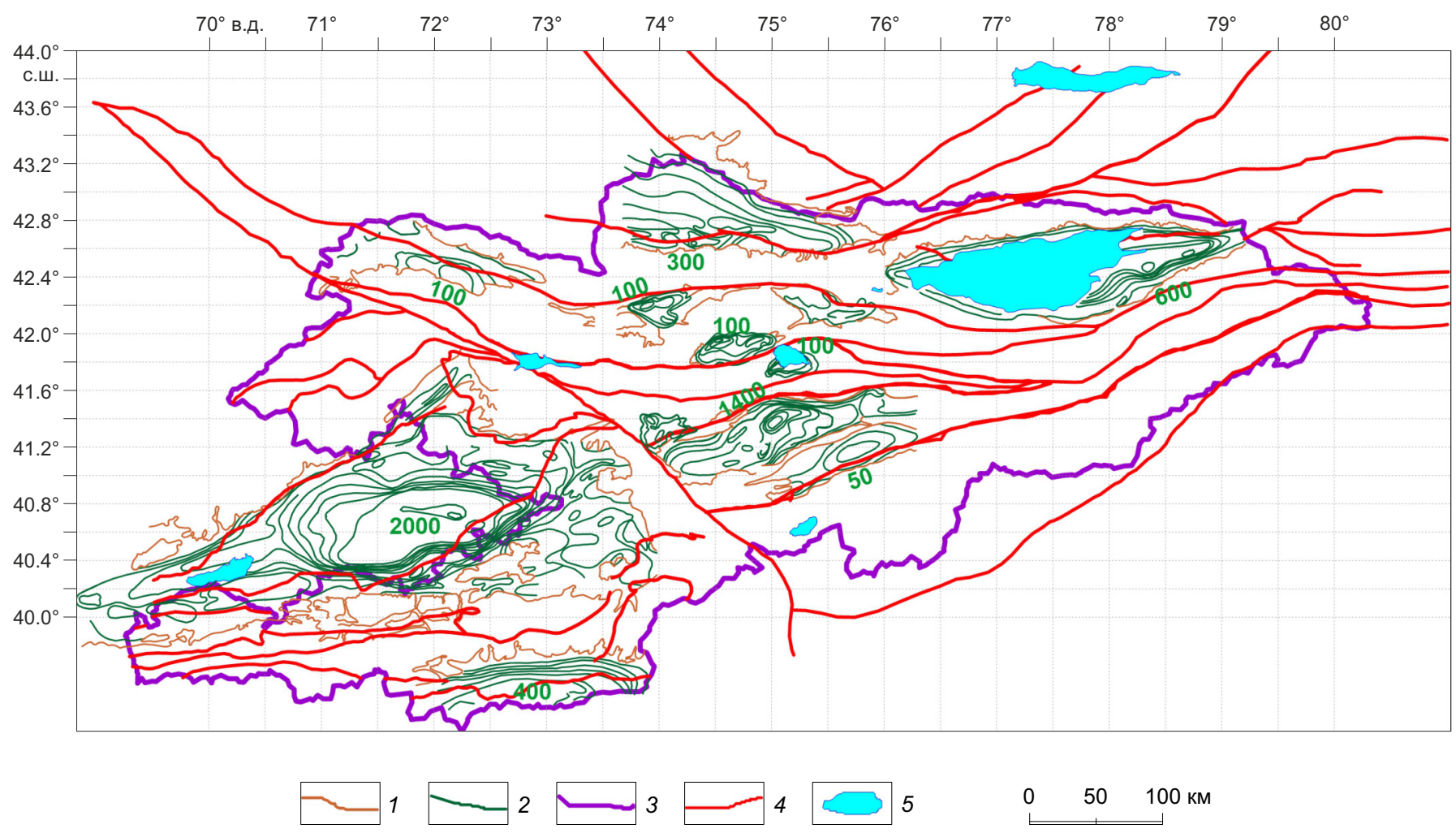

Рис. 15. Карта суммарной проводимости (карта S) осадочного чехла для Центрального Тянь-Шаня по данным вертикального электрического зондирования (ВЭЗ) и дипольного электрического зондирования (ДЭЗ) [Melnikova, 1991].

1 - изогипсы поверхности подошвы палеозойских отложений; 2 - изолинии продольной проводимости S (в сименсах); 3 границы Киргизской Республики; 4 - крупные разломные структуры; 5 - водоемы.

Fig. 15. Map of the Central Tien Shan showing the total conductivity $S$ of the sedimentary cover according to the vertical electric sounding (VES) and dipole electric sounding (DES) data [Melnikova, 1991].

1 - contours of the bottom surface of the Paleozoic sediments; 2 - contours of longitudinal conductivity S (in Siemens); 3 - state borders of the Kyrgyz Republic; 4 - large faults; 5 - water basins. 
собой спорадически расположенные флюидизированные и механически ослабленные, а также возможные зоны частичного плавления [Bakirov, 1984; Bakirov et al., 1996], достигает 300 См [Batalev et al., 1989; Trapeznikov et al., 1997; Rybin et al., 2008].

Согласно карте S (рис. 15), наиболее высокие значения суммарной продольной проводимости впадин рассматриваемой территории характерны для Южного и Западного Тянь-Шаня, где они достигают 14002000 См. Наименьшие значения $\mathrm{S}$ характерны для ряда впадин Северного и Срединного Тянь-Шаня. К востоку от Таласо-Ферганского разлома значения суммарной проводимости гораздо ниже, чем к западу [Melnikova, 1991].

В целом, распределение скоростных характеристик по глубине в пределах земной коры и верхней мантии Центрального Тянь-Шаня коррелируется не только с геоэлектрической, но и с прочностной моделью, рассчитанной для геотраверса «MANAS» в работе [Makarov et al., 2010]. В связи с этим можно предположить, что субгоризонтальные границы скоростной модели могут отображать разделы земной коры с различными прочностными характеристиками. Тектонические нарушения на сейсмическом разрезе МОВ-ОГТ выделялись по резким изменениям времени регистрации отражений и уменьшению их амплитуд. Отраженные волны, созданные глубинными разломами, позволяют проследить их простирание с глубиной и определить форму. В разломной тектонике земной коры Тянь-Шаня лидирующую роль играют тектонические нарушения листрической формы. Особенность поведения этих структур заключается в том, что они имеют субвертикальное залегание вблизи дневной поверхности, а с глубиной их угол падения уменьшается, и на различных пространственно-масштабных уровнях они образуют пологие границы. В области выполаживания разломов образуются субгоризонтальные расслоенные зоны, которые могут быть границами волноводов и коровых проводящих слоев.

Возникновение геоэлектрических аномалий, имеющих хорошую согласованность (корреляцию) с волноводами, может быть обусловлено разуплотнением горных пород с заполнением порово-трещинного пространства флюидом [Shmonov et al., 2000; Rybin et al., 2016; Shmonov, Vitovtova, 2017], а на глубине 25 км и более - peзультатом частичного плавления вещества и образования магмы [Bakirov, 1984; Bakirov et al., 1996]. Низкая вязкость волноводов и зон повышенной электропроводности земной коры на различных пространственно-масштабных уровнях оказывает большое влияние на геодинамику коровых процессов. Верхняя граница нижнекоровых волноводов является главным тектоническим разделом в земной коре, где возникает дисгармония между тектоническими структурами и происходит смена стиля и типа деформации [Makarov et al., 2010; Zubovich et al., 2001]. Волновод также является слоем, в котором происходит стирание многих неоднородностей в геофизических полях и деформации которого изостатически компенсируют плотностные неоднородности земной коры.

\section{5. ГРАНИЦА МОХО}

Определение положения и природы границы Мохо очень важно для понимания процессов горообразования и эволюции внутриконтинентального орогена Тянь-Шаня. Принято считать, что граница Мохо является поверхностью раздела между нижней корой и верхней мантией, где скорость распространения продольных сейсмических волн скачкообразно возрастает от 6.9-7.4 до 8.0-8.2 км/с. О природе границы Мохо нет единой точки зрения; принято считать, что переходный слой «кора - мантия» от границы Мохо к верхней мантии может быть результатом либо термодинамических преобразований, либо физико-химических преобразований вещества литосферы, либо напряженно-деформированного состояния геологической среды.

В любом случае границу Мохо и переходный слой от земной коры к верхней мантии можно считать областью активных геологических процессов. Индикаторами современных геодинамических процессов могут служить распределение скоростных характеристик над и под границей Мохо, характер проявления границы (четкий или размытый) и физические свойства горных пород и т.п. Результаты глубинных геофизических исследований могут также свидетельствовать и о положении и динамике границы Мохо в ходе геологической эволюции [Batalev et al., 2011; Bagdassarov et al., 2011]. При этом необходимо отметить, что граница Мохо под Тянь-Шанем не всегда четко выражена, зачастую она расплывчата и, возможно, отражает постепенный переход от нижней коры к мантии. Эта граница может быть обусловлена и движением между земной корой и верхней мантией вдоль поверхности срыва (detachment) [Batalev, 2002; Bataleva, 2005].

Скоростные разрезы, полученные как по данным ГСЗ, так и по данным МОВ-ОГТ [Makarov et al., 2010] вдоль профилей наблюдений, свидетельствуют о гетерогенности структуры и состава геологической среды. Разнообразие ансамбля скоростных аномалий может быть обусловлено также разными геодинамическими обстановками и длительностью тектонического развития.

Северный Тянь-Шань. Общепризнано, что глубина залегания границы Мохо для Чуйской впадины составляет 35-40 км, о чем свидетельствует и перепад продольных скоростей на этой глубине - для разных профилей от 6.6 до 8.1 км/с и от 5.4 до 7.8 км/с. Под Киргизским хребтом граница Мохо установлена на глубине 65 км с граничной скоростью V=7.8-8.0 км/с. Для Иссык-Кульской впадины и ее горного обрамления скачок продольных скоростей происходит на глубине около 50 км - от 5.8 до 7.5 км/с. Следует отметить, что для восточной части Илийской впадины глубина залегания поверхности Мохо для отдельных участков составляет 35 км, продольные скорости меняются от 5.5 до 8.0 км/с, однако в целом для впадины граница поверхности раздела находится на глубине порядка 50 км [Belyaevsky, 
1974; Krestnikov, Nersesov, 1962; Sabitova, 1989; Makarov et al., 2010; Pogrebnoi, Grebennikova, 2012].

В Срединном Тянь-Шане в геофизических моделях граница Мохо проявляется на глубине от 40 до 70 км. В этом тектоническом сегменте граница Мохо занимает по данным МОВ3 аномально низкое положение (порядка 70-75 км) под хребтами Кок-Шаал и СарыДжаз, а под Нарынской впадиной поднимается до глубины 35-40 км. Эта особенность глубинного строения хорошо отражается и в геоэлектрических моделях [Laverov, Makarov, 2005; Makarov et al., 2010]. Сейсмотомографические построения, выполненные различными авторами [Roecker et al., 1993; Vinnik et al., 2004; Adamova, Sabitova, 2004; Zabelina et al., 2013] для земной коры Срединного Тянь-Шаня, свидетельствуют о том, что интервал глубин 35-65 км имеет характеристики переходной зоны кора - мантия. Наиболее резкие изменения скорости прохождения волн для этого тектонического сегмента можно интерпретировать как подошву земной коры.

В Восточном Тянь-Шане граница Мохо расположена на глубине от 50 до 65 км [Zhao et al., 2003]. Карты рельефа поверхности Мохо для Тянь-Шаня, основанные на сейсмологических данных [Laverov, Makarov, 2005], показывают, что существует зеркальное подобие между рельефом Мохо и сглаженным рельефом дневной поверхности складчатого пояса.

В зоне Таласо-Ферганского разлома, которая служит границей между Восточным и Западным Тянь-Шанем, при сравнении скоростей Р-волн в интервале глубин 50-65 км очевидно, что к западу от разлома значения скоростей значительно выше (7.8-8.0 км/с), чем к востоку (7.2 км/с) [Roecker et al., 1993; Vinnik, 1998; Laverov, Makarov, 2005; Sabitova et al., 2009]. В Западном Тянь-Шане распределение скоростных характеристик в целом схоже с таковым в Срединном, граница Мохо находится на глубине от 40 до 70 км.

Таким образом, при анализе поведения скоростей продольных волн для рассматриваемых тектонических элементов можно сделать следующие выводы:

1. На аналогичных глубинах с севера на юг в Северном Тянь-Шане скорости Vр значительно ниже (7.07.1 км/с), чем в Срединном (7.4-7.6 км/с) и Южном (7.4 7.8 км/с) Тянь-Шане [Laverov, Makarov, 2005].

2. Под системами поднятий (Киргизский хребет, Кунгей-Алатоо и Терскей-Алатоо, Кокшаал-Тоо, Алай) скорости Vр остаются довольно низкими до глубины 50-65 км.

3. В рельефе поверхности Мохо находят отражение крупнейшие разломы, - Таласо-Ферганский, Линия

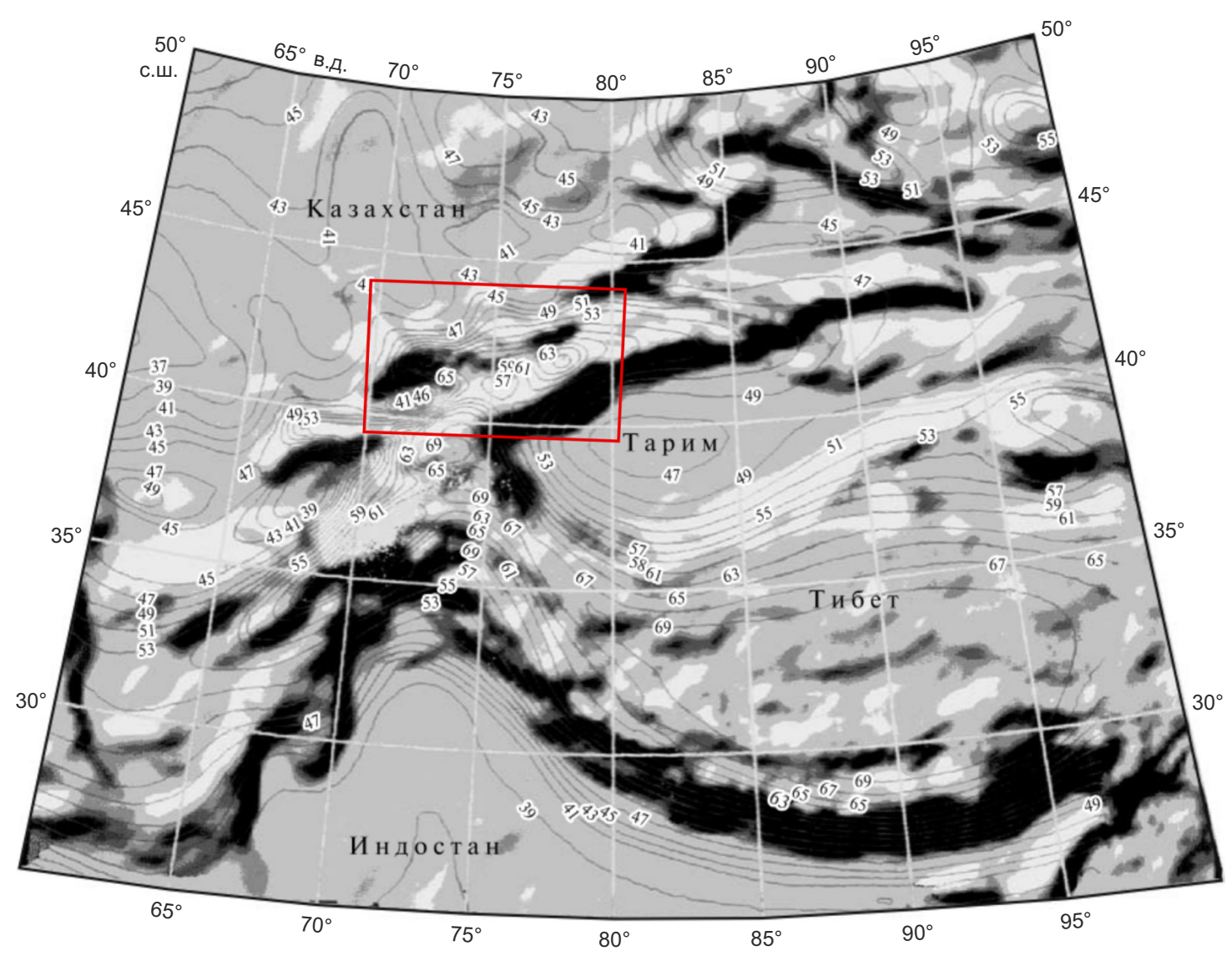

Рис. 16. Карта изоглубин нахождения поверхности Мохоровичича в километрах ниже уровня моря и рельефа дневной поверхности Гималаев и Тянь-Шаня. Красным прямоугольником обозначены границы изучаемой территории [Laverov, Makarov, 2005].

Fig. 16. Map of the iso-depths (km) of the Moho surface below the sea level, and the topography of the Himalayas and Tien Shan. Red box - study area [Laverov, Makarov, 2005]. 
Николаева, Атбаши-Иныльчекский, а также другие разрывные нарушения Тянь-Шаня (рис. 16).

4. Средняя мощность земной коры Тянь-Шаня около 55 км [Laverov, Makarov, 2005], она на 10-15 км больше, чем мощность коры окружающих ороген территорий.

Сопоставление карты изоглубин поверхности Мохо [Laverov, Makarov, 2005] с аналогичной картой, построенной для Тянь-Шаня в работе [Pogrebnoi, Grebennikova, 2012], показало, что рельеф поверхности Мохо, рассчитанный двумя различными способами, практически совпадает при оценке среднеквадратической погрешности в определении глубин в 3.5 км. Таким образом, очевидно, что земная кора в пределах Тянь-Шаня стремится в сторону изостатического равновесия. Примером отклонения от равновесного положения является Ферганский блок (см. рис.1) [Laverov, Makarov, 2005].

\section{6. РАСПРЕДЕЛЕНИЕ ПЛОТНОСТНЫХ ХАРАКТЕРИСТИК}

Геодинамические процессы, происходящие в литосфере Тянь-Шаня, приводят к значительным изменениям приповерхностных структур и характерной концентрации плотностных неоднородностей, проявлением которых являются неоднородности рельефа. Распределение гравитационных аномалий в первую очередь свидетельствует о наличии плотностных неоднородностей осадочного чехла и фундамента и конфигурации разломных структур. Так, например, зоны повышенных значений горизонтальной составляющей градиентов аномалий силы тяжести отражают местоположение и простирание Таласо-Ферганского разлома, Линии Николаева и других крупных тектонических нарушений Тянь-Шаня. Зоне динамического влияния Таласо-Ферганского разлома соответствует полоса отрицательных аномалий северо-западного простирания, которая дискордантно рассекает гравитационные аномалии северовосточного направления. Наиболее четкая взаимосвязь разрывных нарушений, к которым зачастую приурочены гипоцентры сейсмических событий, обнаруживается с аномалиями силы тяжести в изостатической редукции [Artem'yev, 1975; Artem'yev et al., 1993].

Для большей части территории Тянь-Шаня характерно утолщение земной коры, что может быть обусловлено процессами новейшего горообразования, которые, начавшись в неоген-четвертичное время, продолжаются и в настоящий момент. Аномалии гравитационного

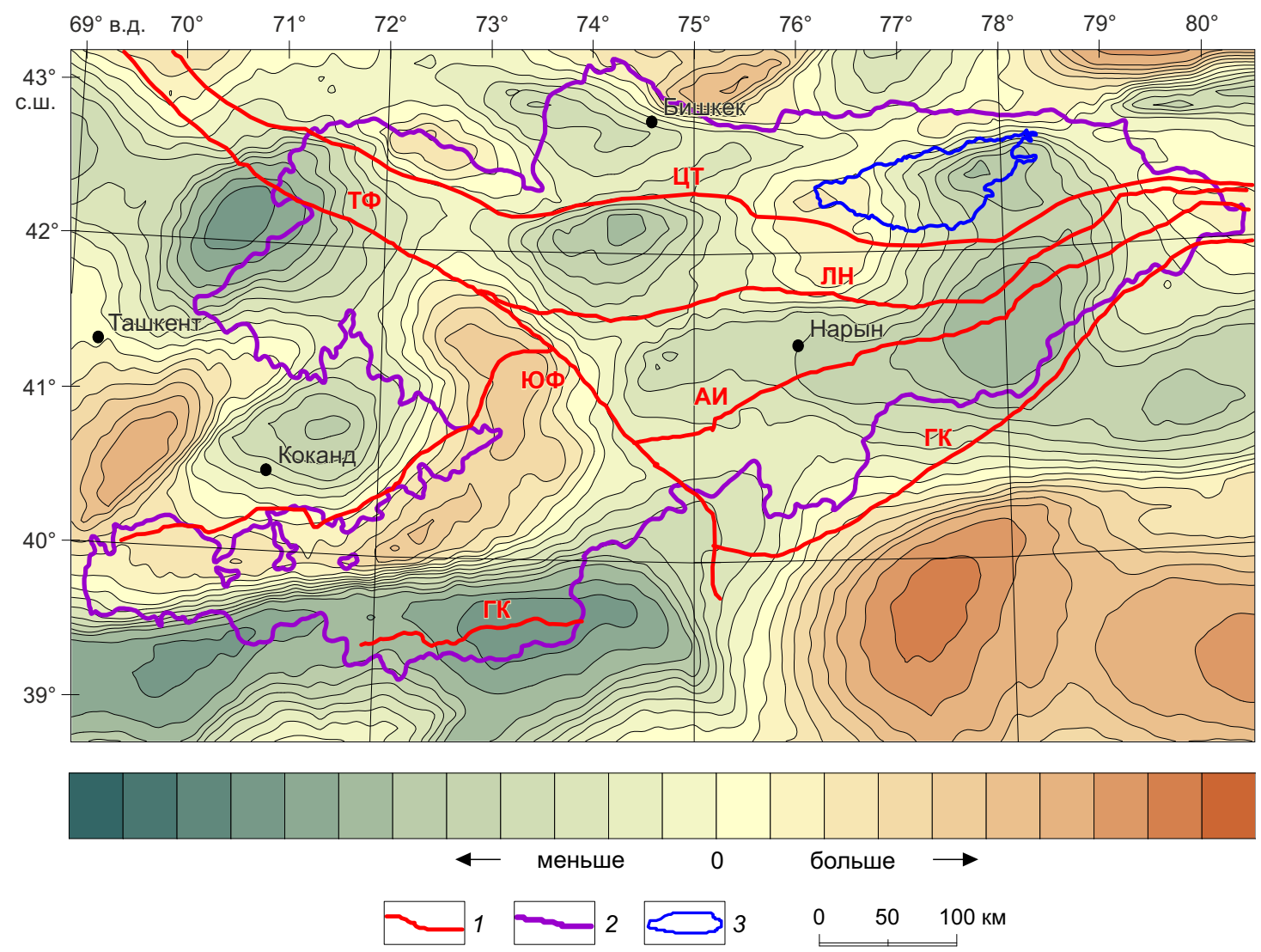

Рис. 17. Карта распределения аномалий гравитационного поля для территории Тянь-Шаня [Bragin, Lobanchenko, 2005]. 1 - крупнейшие разломы: ТФ - Таласо-Ферганский, ЛН - Линия Николаева, ЦТ - Центрально-Терскейский, АИ - АтбашиИныльчекский, ГК - Гиссаро-Кокшаальский, ЮФ - Южно-Ферганский; 2 - границы Киргизской Республики; 3 - граница озера Иссык-Куль.

Fig. 17. Gravity anomalies map of the Tien Shan [Bragin, Lobanchenko, 2005].

1 - major faults: ТФ - Talas-Fergana, ЛН - Nikolaev Line, ЦТ - Central Terskey, АИ - Atbashi-Inylchek, ГК - Gissar-Kokshaal, ЮФ South Fergana; 2 - state borders of the Kyrgyz Republic; 3 - boundary of Lake Issyk-Kul. 
поля обусловлены рельефом, мощностью земной коры, влиянием плотностных неоднородностей, расположенных на различных пространственно-масштабных уровнях (рис. 17). Плотностные модели земной коры, построенные для Тянь-Шаня и позволяющие объяснить в рамках существующей парадигмы особенности распределения силы тяжести, можно встретить в работах [Tal-Virsky, 1982; Yudakhin, 1983; Lobanchenko et al., 1988; Bragin, 2001; Makarov et al., 2010].

Так, принимая во внимание то обстоятельство, что Тянь-Шань находится в условиях субмеридионального сжатия - с севера Тянь-Шань надвигается на Казахский щит, а на юге Таримская плита пододвигается под него, можно объяснить увеличение мощности коры до 60-65 км под Тяньшаньскими горными сооружениями и разуплотнение верхней мантии под Нарынской впадиной, о чем свидетельствует мощная отрицательная гравитационная аномалия. В гравитационном поле Тянь-Шаня преобладают существенные отрицательные аномалии Буге, значения которых увеличиваются к востоку от зоны Таласо-Ферганского разлома. Согласно [Yudakhin, 1986], западная часть Тянь-Шаня сжата в гораздо большей степени, чем восточная, которая как бы «расползается» к северу и к югу. Под крупными впадинами мощность коры относительно сокращена до 40-45 км. В формирование отрицательных гравитационных аномалий вклад мощности коры составляет от 53 до 66 \%. Согласно теории изостазии, вес Тянь-Шаня компенсируется благодаря выталкивающей силе его корней, которые глубоко погружены в маловязкую разогретую мантию [Yudakhin et al., 1991]. При этом наблюдается устойчивая корреляция мощности корового проводящего слоя с результатами гравиметрических наблюдений [Bragin et al., 2001; Rybin, 2011; Batalev, 2014], что является логическим подтверждением разуплотнения нижней части коры.

\section{7. РАСПРЕДЕЛЕНИЕ СЕЙСМИЧНОСТИ}

Очаги землетрясений могут быть приурочены к границам породных комплексов, слоев и/или блоков коры

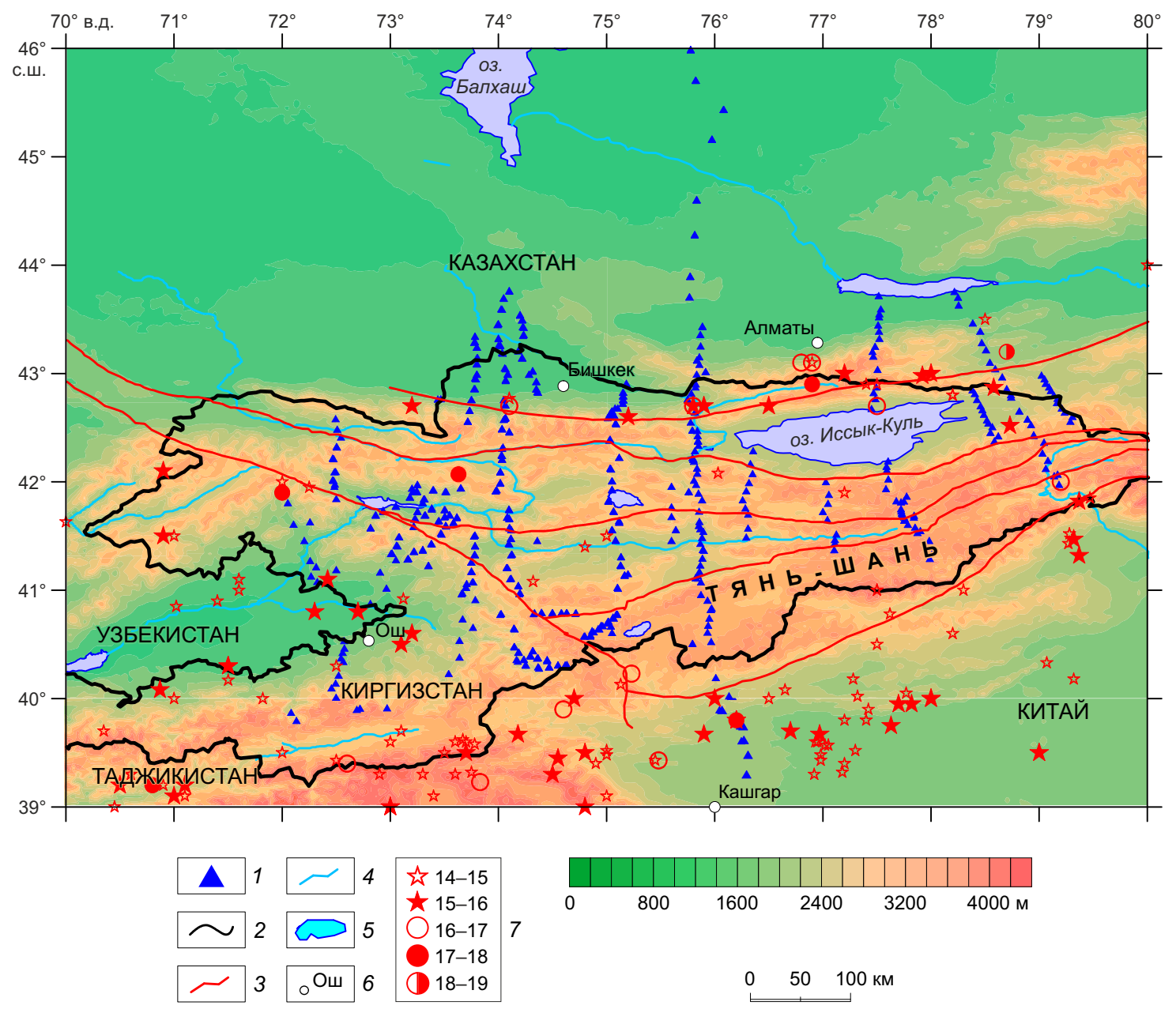

Рис. 18. Карта распределения землетрясений для территории Тянь-Шаня с энергетическим классом 14-19.

1 - пункты МТЗ; 2 - границы Киргизской Республики; 3 - разломы; 4 - реки; 5 - озера; 6 - города; 7 - класс землетрясения по каталогу KNET.

Fig. 18. Earthquake distribution map of the Tien Shan. Energy class 14 to 19.

The energy class values are shown next to the epicenters. 1 - MTS points; 2 - borders of the Kyrgyz Republic; 3 - faults; 4 - rivers; 5 lakes; 6 - towns; 7 - earthquake class according to the KNET catalogue. 
различной реологии, узлам пересечения разломов и плоскостям глубинных горизонтальных тектонических срывов.

Характер распределения геоэлектрических и сейсмических (скоростных) неоднородностей является отражением геодинамических процессов, происходящих в литосфере Тянь-Шаня, например сейсмичности (рис. 18, 19). Процесс коллизионного взаимодействия продолжается на современном этапе тектогенеза внутриконтинентального орогена. Основным индикатором современной активности является сейсмичность, которая неравномерно распределяется в разных тектонических сегментах. Анализ распределения гипоцентров землетрясений может свидетельствовать о реактивации в земной коре древних и ослабленных зон, например
Иссык-Кульского микроконтинента, которые проявляются как ярко выраженные неоднородности в геоэлектрических моделях [Batalev et al., 2011; Batalev, 2014]. Расположение очагов слабых землетрясений в пределах высокоомных объектов, что мы можем наблюдать на геоэлектрической модели, построенной вдоль профиля «Нарын» [Batalev, 2014; Bataleva et al., 2015], очевидно связанных с глубинными проявлениями магматизма, свидетельствует о том, что разрядка напряжений происходит на контакте блоков основных пород с породами, обладающими другими петрофизическими и реологическими свойствами.

В работах [Kissin, Ruzajkin, 1997; Zubovich et al., 2001; Batalev et al., 2013; Batalev, 2014] рассматривалось пространственное положение гипоцентров землетрясений

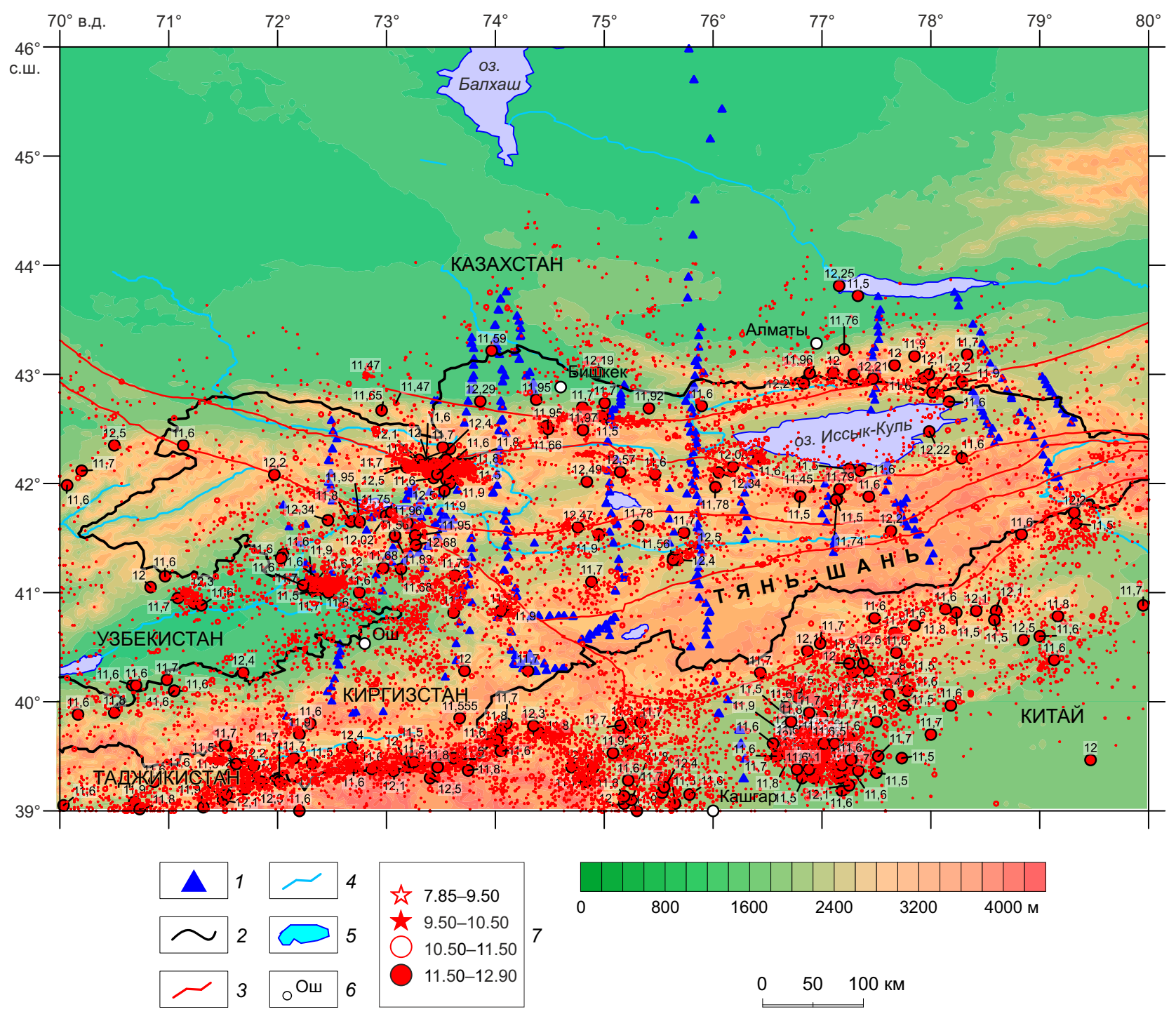

Рис. 19. Карта распределения землетрясений для территории Тянь-Шаня с энергетическим классом 8-12, значения которых показаны рядом с эпицентрами.

1 - пункты МТЗ; 2 - границы Киргизской Республики; 3 - разломы; 4 - реки; 5 - озера; 6 - города; 7 - класс землетрясения по каталогу KNET.

Fig. 19. Earthquake distribution map of the Tien Shan. Energy class $\sim 8$ to 12 .

The energy class values are shown next to the epicenters. 1 - MTS points; 2 - borders of the Kyrgyz Republic; 3 - faults; 4 - rivers; 5 lakes; 6 - towns; 7 - earthquake class according to the KNET catalogue. 
в 100-километровой полосе вдоль линии профиля «Нарын». Установлено, что все очаги землетрясений залегают в верхней и средней части земной коры (на глубине менее 30 км), тогда как на таримском участке землетрясения происходят на глубине до 100 км. Это можно объяснить существованием различных геодинамических обстановок в литосфере Тянь-Шаня, что отражено в геодинамических моделях (см. рис. 1).

Распределение сейсмических событий, произошедших на территории Тянь-Шаня и зарегистрированных различными сейсмическими сетями (NNC, KRNET, KNET и др.) (см. рис. 2), позволяет сегментировать рассматриваемую территорию по энергетическому классу и наибольшей плотности землетрясений (см. рис. 18; рис. 19). Так, если рассматривать распределение эпицентров сильнейших землетрясений для Северного Тянь-Шаня (Северо-Тяньшаньская сейсмогенная зона), то они образуют узкую полосу, включающую в себя такие землетрясения, как Беловодское $(1885, \mathrm{M}=6.9)$, Верненское (1887, M=7.3), Чиликское (1889, M=8.4), Кеминское (1911, M=8.2), Чаткальское (1946, M=7.8), Сусамырское (1992, M=7.3). Мощные землетрясения характерны и для Южного Тянь-Шаня, включающего в себя Кокшаальский, Заалайский и Гиссарский хребты, например Уратюбинское (1897, M=6.5), Кашкарское (1902, M=7.8), Каратагское (1907, M=7.5), Сарезское (1911, M=7.1), Куршабское (1924, М=6.5), Нуринское $(2008, M=6.6)$. Именно эти две полосы как бы очерчивают Тянь-Шаньский блок с севера и юга.

Что касается территории Срединного Тянь-Шаня, то происходящие здесь землетрясения обладают намного меньшей энергией по сравнению с Северным и Южным Тянь-Шанем, и частота возникновения сейсмических событий свидетельствует о слабой активности региона. Землетрясения 14-15-го энергетического класса в целом происходят в тех же пределах, что и сильнейшие землетрясения Тянь-Шаня, вследствие чего узкие полосы становятся более выраженными и отчетливо проявляются западная и восточная границы Тяньшаньского блока, отраженные в распределении сейсмичности. Сегментация Тянь-Шаня по отношению к зоне Таласо-Ферганского разлома ярко выражена в поведении эпицентров сейсмических событий 8-12-го энергетического класса (рис. 19).

Карты эпицентров слабых землетрясений, построенные для каждого энергетического класса отдельно, отличаются лишь плотностью изображенных эпицентров, и, в соответствии с законом Гутенберга-Рихтера, для сейсмических событий с $\mathrm{K}=8$ общее число произошедших землетрясений максимально. Для западной части Тянь-Шаня плотность эпицентров сейсмических событий с К=8-12 в несколько раз больше ( $3-4$ раза), чем для восточной, т.е. по разные стороны от ТаласоФерганского разлома уровень сейсмической активности различен. Подавляющее большинство землетрясений вне впадины Тянь-Шаня характеризуются слабой сейсмичностью (Ферганская) либо асейсмичны (Нарынская). В центре Иссык-Кульской впадины, под озером Иссык-Куль, сейсмические события случаются крайне редко. Структурная приуроченность крупных $(\mathrm{M} \geq 6.5)$ и слабых сейсмических событий различна. Крупные землетрясения, как правило, приурочены к бортам межгорных впадин, слабые - к окружающим впадины хребтам.

Таким образом, в распределении землетрясений четко проявляются зоны Северного, Срединного и Южного Тянь-Шаня, а также проявляется сегментация Западного и Восточного Тянь-Шаня относительно Таласо-Ферганского разлома.

\section{8. ПОЛОЖЕНИЕ ВОЛНОВОДОВ И ПРОВОДНИКОВ}

В тектонически активных регионах присутствие волноводов обычно наблюдается глубине 15-20 км, что может быть обусловлено изменением реологии горных пород под влиянием повышенной температуры [Giese, Tiemann, 1975]. Практически везде, где на профилях выполнялись глубинные сейсмические и магнитотеллурические зондирования, наблюдается хорошая корреляция зон повышенной электропроводности с зонами инверсии скоростей в верхней части земной коры (глубина 10-20 км) [Bagmanova et al., 2014; Batalev, 2014].

Для нижней коры результаты магнитотеллурических исследований гораздо чаще свидетельствуют о наличии проводящего слоя, чем сейсмические данные о наличии волновода. Это может быть обусловлено проблемами, возникающими при интерпретации данных о распределении скоростей в непосредственной близости к границе М, которая является природным экраном для преломленных волн от низов коры. Однако исключать наличие ослабленного слоя в низах коры, который соответствует слою повышенной электропроводности, но плохо выражен в сейсмических скоростях, нельзя. Что касается метода МОВ-ОГТ (метод субвертикальных отраженных волн), который был выбран в качестве глубинного сейсмического метода как дополнение к методу МТЗ при проведении работ вдоль трансекта «MANAS», то он вызывает гораздо больше доверия среди геофизиков и благодаря ему была доказана расслоенность хрупкой коры, существование зон повышенной расслоенности и закономерности в их распределении по глубине. Комплекс геолого-геофизических данных указывает на то, что в глубинных частях земной коры современного Тянь-Шаня имеется множество геоэлектрических, скоростных, плотностных и других неоднородностей, причиной образования которых могут быть метаморфические процессы и формирование гранитоидных магм [Bakirov, 1984; Bakirov et al., 1996]. Нижнекоровые волноводы могут представлять собой аналоги полей мигматитов, а линзовидные и не имеющие формы тела волноводов в верхней части коры, возможно, образованы кристаллизующимися интрузиями гранитоидов, что является типичным для таких горно-складчатых областей, как Тянь-Шань.

Сейсмическими исследованиями вдоль профиля было установлено, что так же, как и в геоэлектрических 
моделях, ярко выражены нарушения листрической формы: они почти вертикальны у поверхности, затем их угол уменьшается, и на глубине 20-25 км и около 4050 км они образуют пологие границы. Это подтверждает лидирующую роль листрических разломов в тектонической структуре коры различных по возрасту и характеру эволюции тектонических сегментов ТяньШаня. Было отмечено также, что в области выполаживания разломов формируются субгоризонтальные расслоенные зоны, которые и являются сейсмическими границами (К1).

Глубинные разломы листрической формы выделяются по данным электромагнитных исследований магнитотеллурического зондирования. На рис. 11, 12 приведены примеры таких структур для рассматриваемых нами тектонических сегментов: аномалии повышенной проводимости имеют здесь листрическую форму и выполаживаются к средней или нижней коре, где расположены субгоризонтальные проводники. Эти зоны в средней или нижней коре могут служить зонами срыва, по которым проскальзывает верхняя кора, так называемый детачмент зоны.

Согласно современным исследованиям [Zubovich et al, 2001; Batalev et al., 2011; Rybin, 2011; Batalev, 2014; Bataleva et al., 2015], существует взаимосвязь между процессами подготовки сейсмических событий ТяньШаня и вариациями электромагнитных параметров, которые отражают напряженно-деформированное состояние земной коры. Региональные аномалии высокой электропроводности в условиях внутриконтинентального орогена связаны с проявлениями сейсмической активности [Batalev et al., 2011]. Для анализа было использовано 4431 землетрясение с К>6, зарегистрированных шестью сейсмическими сетями (рис. 20), эпицентры которых находятся вблизи 76-го меридиана. На рис. 20 показано, что глубина залегания гипоцентров землетрясений Тянь-Шаня очень редко превышает 20-25 км [Zubovich et al., 2001], т.е. очаги сейсмических событий приурочены к верхней (хрупкой) коре и исчезают в зоне корового проводящего слоя.

Как отмечалось выше, для Тянь-Шаня является характерным то, что в разных по геологической структуре, геодинамической и тектонической активности сегментах наблюдается хорошая корреляция между аномалиями повышенной электропроводности, волноводами и характером распределения очагов землетрясений в земной коре. Данный факт подтверждает предположение о реологической ослабленности средней коры, в скоростных характеристиках данная ослабленность проявляется как наличие волновода.

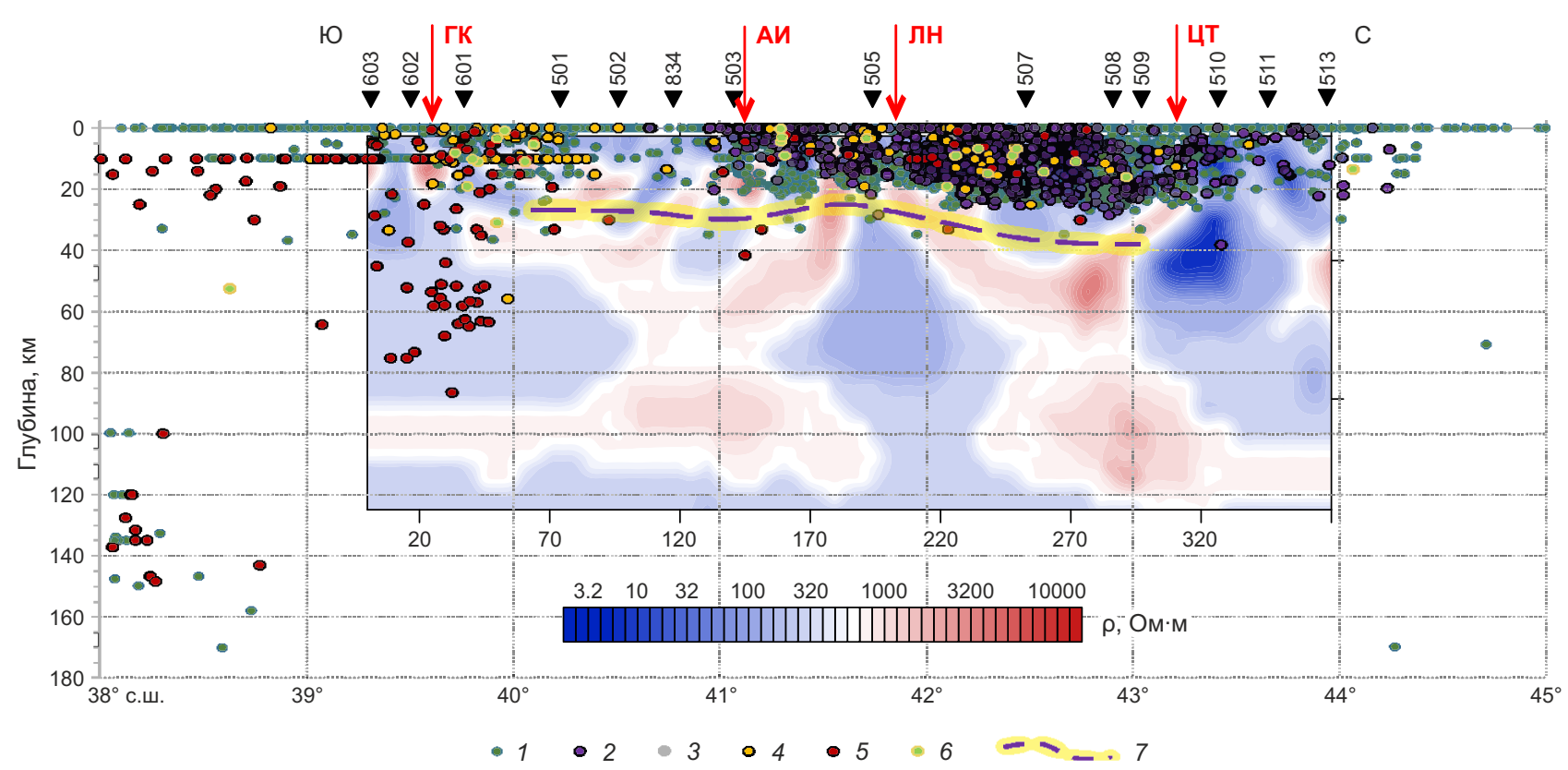

Рис. 20. Расположение гипоцентров очагов землетрясений с энергетическим классом К $\geq 6$ для периода 2000-2019 гг. по каталогам сейсмических сетей.

1 - NNC; 2 - KRNET; 3 - KNET; 4 - CAIIG; 5 - SOME; 6 - BJI; 7- кровля корового проводящего слоя, для геоэлектрической модели по профилю «Нарын» вдоль $\lambda=76^{\circ}$. Расположение профиля и геоэлектрическая модель на рис. 11. Разрез скоростей поперечных волн вдоль профиля показан на рис. 8. Красными стрелками обозначены крупнейшие разломы: ГК - ГиссароКокшаальский, АИ - Атбаши-Иныльчекский, ЛН - Линия Николаева, ЦТ - Центрально-Терскейский. Кружки - гипоцентры землетрясений, черные стрелки - расположение стационарных сейсмических станций вдоль линии профиля.

Fig. 20. Locations of earthquake hypocenters $(\mathrm{K} \geq 6)$ recorded in the 2000-2019 seismic catalogues.

1 - NNC; 2 - KRNET; 3 - KNET; 4 - CAIIG; 5 - SOME; 6 - BJI; 7 - top of the crustal conductive layer. Geolectric model for the Naryn profile along $\lambda=76^{\circ}$ (see Fig. 11). The S-wave velocities section along the profile is shown in Fig. 8. Major faults (red arrows and letters): $\Gamma \mathrm{K}-$ Gissar-Kokshaal, АИ - Atbashi-Inylchek, ЛН - Nikolaev Line, ЦТ - Central Terskey. Circles - earthquake hypocenters, black arrows - the location of stationary seismic stations along the profile. 
Такое толкование сейсмических волноводов подтверждается их корреляцией с распределением в коре очагов землетрясений.

В верхней части земной коры (H=5-15 и Н=15-25 км) волноводы проявляются фрагментарно. Самое широкое развитие волноводов в земной коре Тянь-Шаня характерно для глубины $\mathrm{H}=25-35$ км, они оконтуривают киргизскую часть Тянь-Шаня и протягиваются полосой параллельно Таласо-Ферганскому разлому к востоку от него. На больших глубинах (35-50 км и 50-65 км) волноводы развиты в гораздо меньшей степени и закономерности в их проявлении не прослеживается. В Западном Тянь-Шане в Ферганской впадине и ее восточном горном обрамлении практически на всех глубинах волноводы отсутствуют.

Таким образом, волноводы распространены в верхней и нижней коре преимущественно на глубине около 15 км и 25-35 км. Наиболее существенное их проявление имеет место на глубине от 30 до 40 км на юго-западе и юго-востоке киргизской части Тянь-Шаня.

\section{9. ЗАКЛЮЧЕНИЕ}

В связи с разнообразием существующих геофизических методов при анализе объемно-пространственной сегментации литосферы Тянь-Шаня возникает проблема выбора наиболее информативных из них. Принимая во внимание то, что зона Атбаши-Иныльчекского разлома (граница между Южным и Срединным Тянь-Шанем) в магнитном поле практически не отражается, результаты магниторазведочных исследований авторами не рассматривались.

Анализ гравиметрических данных показал наличие крупных разуплотненных объектов в нижней коре и верхней мантии Срединного и Южного Тянь-Шаня особенно, в его западной части.

Глубинное строение крупнейших разломных структур, которые служат границей основных тектонических элементов Тянь-Шаня, лучше всего проявляется в геоэлектрических и сейсмотомографических моделях, впрочем, как и положение проводящих слоев и волноводов. В связи с этим проведено сопоставление геофизических моделей, полученных по результатам длительных полевых наблюдений как в рамках реализации крупных международных проектов, так и при выполнении различных экспериментов, например детальном изучении геоэлектрической структуры территории Бишкекского геодинамического полигона, с данными геологических исследований и новыми тектоническими представлениями. Данное сопоставление позволило более обоснованно обсуждать сходства и различия выявленных геофизических аномалий для различных тектонических элементов Тянь-Шаня, сделать выводы об их природе и найти геофизические аномалии-индикаторы геодинамических обстановок, что принципиально важно для изучения и понимания геодинамических процессов в комплексе с геологическими данными. В качестве структурных признаков нами рассматривались: наличие глубинных разломных структур, градиентных зон на границах раздела Конрада, Мохо, подошвы литосферы, как индикаторы использовались глубины залегания гипоцентров сейсмических событий, распределение теплового потока на глубине, выходы минеральных источников вод и присутствие в них мантийного гелия.

Прежде всего необходимо констатировать существенную корреляцию региональных аномалий электропроводности, распределения скоростных характеристик геологической среды и аномалий потенциальных полей со структурно-тектоническими зонами Северного, Срединного и Южного Тянь-Шаня, а также Восточного и Западного.

Совместный анализ сейсмотомографических построений для исследуемых тектонических сегментов по объемным моделям продольных и поперечных волн [Roecker et al., 1993; Vinnik et al., 2004; Adamova, Sabitova, 2004; Zabelina et al., 2013] позволил сделать следующие выводы:

- сегментация земной коры Тянь-Шаня, установленная для новейшего орогенного этапа его эволюции по геологическим, геофизическим и геоморфологическим данным, проявляется на различных пространственно-масштабных уровнях литосферы региона;

- мощность земной коры на рассматриваемой территории изменчива, наименьшая мощность ( 35-40 км) характерна для Чуйской и Нарынской впадин, максимальная достигает 70-75 км под горными сооружениями Южного Тянь-Шаня;

- наиболее высокое содержание высокоскоростных коровых и верхнемантийных аномалий характерно для такого тектонического сегмента, как Южный Тянь-Шань;

- наиболее отчетливо на представленных сейсмотомографических срезах выражены границы тектонических сегментов на глубине 0-15 и 55-65 км в модели [Roecker et al., 1993].

Границы блоков Северного, Срединного и Южного Тянь-Шаня выражены не столь резко, как Восточного и Западного, и частично отличаются от их границ, выявленных для земной коры по геолого-геофизическим данным.

На основе анализа существующих сейсмотомографических построений для Тянь-Шаньского орогенического пояса удалось дифференцировать основные тектонические элементы Тянь-Шаня - Северный, Срединный и Южный - в скоростных характеристиках геологической среды.

Поперечная сегментация в скоростной структуре литосферы Тянь-Шаня выражена более ярко, чем продольная. Наиболее контрастно проявлены границы основных тектонических элементов на срезах 0-5 км и 55-65 км. Менее контрастны границы Срединного Тянь-Шаня, причем местами эти границы отличаются от тех, которые выделены по геолого-геофизическим данным о новейшей структуре земной коры. В целом, для земной коры внутриконтинентального орогена ТяньШаня характерна более низкоскоростная структура 
по сравнению с окружающими его стабильными регионами [Bakirov, 2006].

Среди рассмотренных геофизических моделей наиболее значимые результаты по определению границ тектонических сегментов получены в геоэлектрических моделях:

- отчетливо проявлены границы основных тектонических сегментов земной коры Тянь-Шаня, установленных для новейшего орогенного этапа его эволюции по геолого-геофизическим данным;

- субвертикальные проводящие зоны в верхней и средней коре, которые служат границами тектонических сегментов, характеризуются большой мощностью и низким сопротивлением - 100-10 Ом•м;

- нижнекоровый проводящий слой, залегающий на глубине 40-60 км, с сопротивлением менее 100 Ом•м, фрагментарно отсутствует для Срединного Тянь-Шаня;

- существует взаимосвязь аномалий повышенной электропроводности с волноводами (зонами механически ослабленной коры);

- наиболее ярко на представленных геоэлектрических разрезах выражена граница тектонических сегментов Восточного и Западного Тянь-Шаня - ТаласоФерганский разлом;

- границы тектонических сегментов Северного, Срединного и Южного Тянь-Шаня выражены иначе, чем Восточного и Западного;

- наиболее контрастная граница тектонических сегментов проходит по Линии Николаева, которая проявляется в геоэлектричиских моделях серией разломных структур, что подтверждается по геологическим данным.

Для формаций сутурных (шовных) зон, например Линии Николаева, характерно присутствие углеродистых отложений, в том числе и графитсодержащих сланцев, которые обладают высокой электропроводностью. Вместе с тем шовные зоны являются зонами транспортировки флюидопотоков. Именно сочетанием этих факторов можно объяснить природу глубинной зоны повышенной электропроводности, приуроченной к Линии Николаева. Одновременно эта разломная зона служит границей между Северным и Срединным Тянь-Шанем. Одним из источников нижнекоровых флюидов может быть процесс дегидратации минералов, содержащих связанную воду, в условиях современной тектонической активизации Тянь-Шаня - в этом случае могут возникать достаточно яркие субгоризонтальные нижнекоровые аномалии электропроводности.

Сопоставление моделей распределения электропроводности с результатами сейсмотомографических построений, региональной сейсмичностью показывает четкую корреляцию проводников в нижней части земной коры на глубине 30-50 км и волноводов. Возможно, они сложены частично расплавленными массами (мигмами) [Bakirov, 1984; Bakirov et al., 1996] и играют роль смазки в зонах срыва, что может приводить к деформации масс в верхней части земной коры.

\section{0. ЛИТЕРАТУРА / REFERENCES}

Adamova A.A., Sabitova T.M., 2001. The Tien Shan Velocity Structure Determined from the Travel Times of P- and S-Waves Using Seismic Tomography. In: News Letter of the European Geophysics Society (78). CD-ROM (in Russian) [Адамова А.А., Сабитова Т.М. Скоростная структура ТяньШаня, определенная по данным времен пробега Р- и S-волн с помощью сейсмической томографии // Новостная рассылка Европейского геофизического общества. 2001. № 78. CD-ROM].

Adamova A.A., Sabitova T.M., 2004. Three-Dimensional Velocity Model of the Tien Shan Crust According to Seismic Tomography Data. Izvestiya, Physics of the Solid Earth 5, 58-68 (in Russian) [Адамова А.А., Сабитова T.M. Tpexмерная скоростная модель земной коры Тянь-Шаня по данным сейсмотомографии // Физика Земли. 2004. № 5. C. 58-68].

Adamova A.A., Sabitova T.M., Mirkin E.L., Bagmanova N.Kh., 2006. Models for Block Approximation of Velocity Distribution Using SPHYPIT 90 (S. Roecker Algorithm). In: A.B. Bakirov (Ed.), The Earth's Crust and Upper Mantle of the Tien Shan in Connection with Geodynamics and Seismicity. Ilim, Bishkek, p. 9-18 (in Russian) [Адамова А.А., Сабитова Т.М., Миркин Е.Л., Багманова Н.Х. Модели для блочной апроксимации распределения скорости с использованием программы SPHYPIT 90 (алгоритм С. Рекера) // Земная кора и верхняя мантия Тянь-Шаня в связи с геодинамикой и сейсмичностью / Ред. А.Б. Бакиров. Бишкек: Илим, 2006. С. 9-18].

Aptikaeva O.I., 2018. Attenuation in Lithosphere of Western Tien Shan. Space and Time 1-2 (31-32), 224-231 (in Russian) [Аптикаева О.И. Затухание в литосфере Западного Тянь-Шаня // Пространство и время. 2018. Т. 1-2. № 31-32. C. 224-231]. https://doi.org/10.24411/22267271-2018-11082.

Aptikaeva O.I., Aptikaev S.F., Kopnichev Yu.F., Rogozhin E.A., 1996. Inhomogeneities in the Lithosphere and Asthenosphere of the Turan Plate and South Tien Shan: Implications for Tectonics and Seismicity. Izvestiya. Physics of the Solid Earth 32 (2), 89-99.

Artem'yev M.E., 1975. Isostasy of the Territory of the USSR. Nauka, Moscow, 216 р. [Артемьев M.Е. Изостазия территории СССР. М.: Наука, 1975. 216 с.].

Artem'yev M.E., Demyanov G.V., Kaban M.K., Kucherenko V.A., 1993. Density Heterogeneities of the Gravitational Field of the Lithosphere of Northern Eurasia. Izvestiya, Physics of the Solid Earth 5, 12-23 (in Russian) [Артемьев М.Е., Демьянов Г.В., Кабан М.К., Кучеренко В.А. Плотностные неоднородности гравитационного поля литосферы Северной Азии // Физика Земли. 1993. № 5. C. 12-23].

Bagdassarov N., Batalev V., Egorova V., 2011. State of Lithosphere beneath Tien Shan from Petrology and Electrical Conductivity of Xenoliths. Journal of Geophysical Research: Solid Earth 116, B01202. https://doi.org/10.1029/2009 JB007125.

Bagmanova N.Kh., Mirkin E.L., 2018. Results of Interpretation of a High-Velocity Seismotomographic Model of the 
Tien Shan Lithosphere. Bulletin of the National Academy of Sciences of the Kyrgyz Republic 1, 47-54 (in Russian) [Багманова Н.Х., Миркин Е.Л. Результаты интерпретации скоростной сейсмотомографической модели литосферы Тянь-Шаня // Известия НАН КР. 2018. № 1. С. 47-54].

Bagmanova N.Kh., Mirkin E.L., Sabitova T.M., 2014. Waveguides in the Crust of the Tien Shan. Bulletin of the Institute of Seismology, National Academy of Sciences of the Kyrgyz Republic 1 (3), 31-38 (in Russian) [Багманова H.X., Миркин Е.Л., Сабитова Т.М. Волноводы в земной коре Тянь-Шаня // Вестник Института сейсмологии НАН КР. 2014. T. 1. № 3. C. 31-38].

Bakirov A.B., 1984. Endogenous Geological Formations of the Tien Shan. In: Metamorphic Formations. Ilim, Frunze, 215 p. (in Russian) [Бакиров А.Б. Эндогенные геологические формации Тянь-Шаня // Метаморфические формации. Фрунзе: Илим, 1984. 215 с.].

Bakirov A.B. (Ed.), 2006. The Earth's Crust and Upper Mantle of the Tien Shan in Connection with Geodynamics and Seismicity. Ilim, Bishkek, 116 p. (in Russian) [Земная кора и верхняя мантия Тянь-Шаня в связи с геодинамикой и сейсмичностью / Ред. А.Б. Бакиров. Бишкек: Илим, 2006. 116 с.].

Bakirov A.B., Lesik O.M., Lobanchenko A.P., Sabitova T.M., 1996. Indicators of Contemporary Deep Magmatism in the Tien Shan. Russian Geology and Geophysics 37 (12), 42-53 (in Russian) [Бакиров А.Б., Лесик О.М., Лобанченко А.П., Сабитова Т.М. Признаки современного глубинного магматизма в Тянь-Шане // Геология и геофизика. 1996. T. 37. № 12. C. 42-53].

Bakirov A.B., Maksumova R.A., 2001. Geodynamic Evolution of the Tien Shan Lithosphere. Russian Geology and Geophysics 42 (10), 1435-1443 (in Russian) [Бакиров А.Б., Максумова Р.А. Геодинамическая эволюция литосферы Тянь-Шаня // Геология и геофизика. 2001. Т. 42. № 10. C. 1435-1443].

Batalev V.Yu., 2002. Deep Structure and Geodynamics of the Western Part of the Kyrgyz Tien Shan According to Magnetotelluric and Magnetic Variational Sounding Data. PhD Thesis (Candidate of Geology and Mineralogy). Novosibirsk, 139 p. (in Russian) [Баталев В.Ю. Глубинное строение и геодинамика западной части Киргизского Тянь-Шаня по данным магнитотеллурических и магнитовариационных зондирований: Дис. ... канд. геол.-мин. наук. Новосибирск, 2002.139 с.].

Batalev V.Yu., 2014. The Structure and State of the Lithosphere of the Central Tien Shan (According to Deep Magnetotelluric Sounding Data). PhD Thesis (Doctor of Geology and Mineralogy). Novosibirsk, 282 p. (in Russian) [Баталев В.Ю. Структура и состояние вещества литосферы Центрального Тянь-Шаня (по данным глубинных магнитотеллурических зондирований): Дис. ... докт. геол.мин. наук. Новосибирск, 2014. 282 с.].

Batalev V.Y., Bataleva E.A., 2013. The State of the Lithosphere in the Junction Zone of Tarim and Tien Shan According to the Petrological Interpretation of the Magnetotelluric Data. Izvestiya, Physics of the Solid Earth 49, 384-391. https://doi.org/10.1134/S1069351313030026.
Batalev V.Yu., Bataleva E.A., Matyukov V.E., Rybin A.K., 2013. Deep Structure of the Western Area of the TalasFergana Fault According to Magnetotelluric Sounding Results. Lithosphere 4, 136-145 (in Russian) [Баталев В.Ю., Баталева Е.А., Матюков В.Е., Рыбин А.К. Глубинное строение западной части зоны Таласо-Ферганского разлома по результатам магнитотеллурических зондирований // Литосфера. 2013. № 4. С. 136-145].

Batalev V.Yu., Bataleva E.A., Matyukov V.E., Rybin A.K., Egorova V.V., 2011. The Lithospheric Structure of the Central and Southern Tien Shan: MTS Data Correlated with Petrology and Laboratory Studies of Lower-Crust and UpperMantle Xenoliths. Russian Geology and Geophysics 52 (12), 1592-1599. https://doi.org/10.1016/j.rgg.2011.11.005.

Batalev V.Yu., Berdichevsky M.N., Golland M.L., Golubtsova N.S., Kuznetsov V.A., 1989. Interpretation of Deep Magnetotelluric Soundings in the Chuya Intermontane Depression. Izvestiya. Physics of the Solid Earth 9, 42-45 (in Russian) [Баталев В.Ю., Бердичевский М.Н., Голланд М.Л., Голубцова Н.С., Кузнецов В.А. Интерпретация глубинных магнитотеллурических зондирований в Чуйской межгорной впадине // Физика Земли. 1989. № 9. C. 42-45].

Batalev V.Yu., Volykhin A.M., Rybin A.K., Trapeznikov Yu.A., Finyakin V.V., 1993. The Structure of the Crust in the Eastern Part of the Kyrgyz Tien Shan According to MTS and GMTS Data. In: Manifestation of Geodynamic Processes in Geophysical Fields. Nauka, Moscow, p. 96-112 (in Russian) [Баталев В.Ю., Волыхин А.М., Рыбин А.К., Трапезников Ю.А., Финякин В.В. Строение земной коры восточной части Киргизского Тянь-Шаня по данным МТЗ и ГМТЗ // Проявление геодинамических процессов в геофизических полях. М.: Наука, 1993. С. 96-112].

Bataleva E.A., 2005. The Deep Structure of the Largest Fault Zones in the Western Part of the Kirghiz Tien Shan and Modern Geodynamics. PhD Thesis (Candidate of Geology and Mineralogy). Novosibirsk, 200 p. (in Russian) [Баталева Е.А. Глубинная структура крупнейших разломных зон западной части Киргизского Тянь-Шаня и современная геодинамика: Дис. ... канд. геол.-мин. наук. Новосибирск, 2005. 200 с.].

Bataleva E.A., Batalev V.Yu., 2011a. Petrological Interpretation of Deep Magnetotelluric Sounding Results. Herald of KRSU 11 (4), 54-59 (in Russian) [Баталева Е.А., Баталев В.Ю. Петрологическая интерпретация результатов глубинных магнитотеллурических зондирований // Вестник КРСУ. 2011. Т. 11. № 4. С. 54-59].

Bataleva E.A., Batalev V.Yu., 2011b. Reasonableness of Using 2D Modeling for the Talas-Fergana Fault Zone. Herald of KRSU 11 (4), 23-28 (in Russian) [Баталева Е.А., Баталев В.Ю. О возможности применения двумерного моделирования к зоне Таласо-Ферганского разлома // Вестник КРСУ. 2011. Т. 11. № 4. С. 23-28].

Bataleva E.A., Batalev V.Yu., 2011c. Specifics of the Method for Interpreting Magnetotelluric Data on the Talas-Fergana Fault Zone. Herald of KRSU 11 (4), 40-46 (in Russian) [Баталева Е.А., Баталев В.Ю. Особенности методики интерпретации магнитотеллурических данных в зоне 
Таласо-Ферганского разлома // Вестник КРСУ. 2011. T. 11. № 4. C. 40-46].

Bataleva E.A., Batalev V.Yu., 2014a. Manifestation of the Precambrian Issyk-Kul Microcontinent in Geophysical Fields. In: Tectonics of Eurasian Fold Belts: Similarities, Differences, Characteristic Features of Modern Mountain Building, and Regional Generalizations. Proceedings of the XLVI Tectonic Meeting (January 28 - February 01, 2014). Vol. 1. GEOS, Moscow, p. 9-13 (in Russian) [Баталева Е.А., Баталев В.Ю. Проявление докембрийского Иссык-Кульского микроконтинента в геофизических полях // Тектоника складчатых поясов Евразии: сходство, различие, характерные черты новейшего горообразования, региональные обобщения: Материалы XLVI Тектонического совещания (28 января - 1 февраля 2014 г.). М.: ГEOC, 2014. T. 1. С. 9-13].

Bataleva E.A., Batalev V.Yu., 2014b. Permeable Zones of the Tien Shan Lithosphere According to MTS, MOV-CDP, Seismic Tomography and Helium Emanations Data. In: Problems of Geodynamics and Geoecology of Intracontinental Orogens. Abstracts of the Sixth International Symposium (June 2329, 2014). Research Station RAS, Bishkek, p. 96 (in Russian) [Баталева Е.А., Баталев В.Ю. Проницаемые зоны литосферы Тянь-Шаня по данным МТЗ, МОВ-ОГТ, сейсмотомографии и эманаций гелия // Проблемы геодинамики и геоэкологии внутриконтинентальных орогенов: Тезисы докладов Шестого Международного симпозиума (23-29 июня 2014 г.). Бишкек: НС РАН, 2014. С. 96].

Bataleva E.A., Batalev V.Yu., 2015a. Appearance of Fault Structures in Electromagnetic Parameters (for the Territory of the Central Tien Shan). Herald of KRSU 15 (9), 160-164 (in Russian) [Баталева Е.А., Баталев В.Ю. Отражение разломных структур в электромагнитных параметрах (для территории Центрального Тянь-Шаня) // Вестник КРСУ. 2015. T. 15. № 9. С. 160-164].

Bataleva E.A., Batalev V.Yu., 2015b. Design Pseudo Reliefs Major Fault Zones of the Central Tien Shan. Herald of KRSU 15 (3), 104-107 (in Russian) [Баталева Е.А., Баталев В.Ю. Построение псевдорельефов крупнейших разломных структур для территории Центрального Тянь-Шаня // Вестник КРСУ. 2015. Т. 15. № 3. С. 104-107].

Bataleva E.A., Batalev V.Yu., Matyukov V.E., 2011a. The Structure and Characteristics of the Lithosphere of the Central and Southern Tien Shan According to Geoelectrical Data and Seismic Wave Velocities. In: Geodynamic Evolution of the Lithosphere of the Central Asian Mobile Belt (from Ocean to Continent). Proceedings of the Scientific Meeting on the Fundamental Research Programme of the Earth Sciences Section of RAS (October 18-21, 2011). IEC SB RAS, Irkutsk, p. 26-27 (in Russian) [Баталева Е.А., Баталев В.Ю., Матюков В.Е. Структура и характеристики литосферы Центрального и Южного Тянь-Шаня по данным геоэлектрики и скоростей сейсмических волн // Геодинамическая эволюция литосферы ЦентральноАзиатского подвижного пояса (от океана к континенту): Материалы научного совещания по Программе фундаментальных исследований ОНЗ РАН (18-21 октября 2011 г.). Иркутск: ИЗК СО РАН, 2011. С. 26-27].
Bataleva E.A., Batalev V.Yu., Matyukov V.E., Rybin A.K., 2013. Results of Magnetotelluric Data on Western Part of Talas-Fergana Fault. Herald of KRSU 13 (1), 53-57 (in Russian) [Баталева Е.А., Баталев В.Ю., Матюков В.Е., Рыбин А.К. Результаты магнитотеллурических зондирований в западной части Таласо-Ферганского разлома // Вестник КРСУ. 2013. Т. 13. № 1. С. 53-57].

Bataleva E.A., Batalev V.Yu., Rybin A.K., 2011b. Manifestation of Geodynamic Processes in Electrical Conductivity Variations (Based on the Results of Magnetotelluric Studies). In: Current State of the Earth Sciences. Proceedings of the International Conference Dedicated to the Memory of V.I. Khain (February 1-4, 2011). MSU Publishing House, Moscow, p. 193-198 (in Russian) [Баталева Е.A., Баталев В.Ю., Рыбин А.К. Проявление геодинамических процессов в вариациях электропроводности (по результатам магнитотеллурических исследований) // Современное состояние наук о Земле: Материалы Международной конференции, посвященной памяти В.И. Хаина (1-4 февраля 2011 г.). М.: Изд-во МГУ, 2011. C. 193-198].

Bataleva E.A., Batalev V.Yu., Rybin A.K., 2015. Interrelation of Conductivity, Seismic Velocities and the Seismicity for Central Tien Shan Lithosphere. Lithosphere 5, 81-89 (in Russian) [Баталева Е.А., Баталев В.Ю., Рыбин А.К. Взаимосвязь аномалий электропроводности, скоростных характеристик и режима сейсмичности литосферы Центрального Тянь-Шаня // Литосфера. 2015. № 5. C. 81-89].

Bataleva E.A., Buslov M.M., Rybin A.K., Batalev V.Yu., Safronov I.V., 2006. Crustal Conductor Associated with the Talas-Fergana Fault and Deep Structure of the Southwestern Tien Shan: Geodynamic Implications. Russian Geology and Geophysics 47 (9), 1036-1042 (in Russian) [Баталева Е.А., Буслов М.М., Рыбин А.К., Баталев В.Ю., Сафронов И.В. Аномалии электропроводности зоны Таласо-Ферганского разлома и геодинамическая интерпретация глубинной структуры Юго-Западного Тянь-Шаня // Геология и геофизика. 2006. Т. 47. № 9. С. 1036-1042].

Bataleva E.A., Rybin A.K., Batalev V.Yu., Safronov I.V., 2005. Use of Magnetotelluric Sounding to Study Tectonic Disturbances in Rock Masses. Journal of Mining Science 41, 225-231. https://doi.org/10.1007/s10913-005-0087-z.

Bazhenov M.L., 1993. Cretaceous Paleomagnetism of the Fergana Basin and Adjacent Ranges, Central Asia: Tectonic Implications. Tectonophysics 221 (2), 251-267. https:// doi.org/10.1016/0040-1951(93)90335-H.

Belyaevsky N.A., 1974. The Earth's Crust within the USSR Territory. Nauka, Moscow, 280 p. (in Russian) [Беляевский Н.А. Земная кора в пределах территории СССР. М.: Наука, 1974. 280 с.].

Berdichevsky M.N., Sokolova E.Yu., Varentsov I.M., Rybin A.K., Baglaenko N.V., Batalev V.Yu., Golubtsova N.S., Matyukov V.E., Pushkarev P.Yu., 2010. Geoelectric Section of the Central Tien Shan: Analysis of Magnetotelluric and Magnetic Variational Responses along the Naryn Geotraverse. Izvestiya, Physics of the Solid Earth 8, 36-53 (in Russian) [Бердичевский М.Н., Соколова Е.Ю., Варенцов И.М., Рыбин А.К., 
Баглаенко Н.В., Баталев В.Ю., Голубцова Н.С., Матюков В.Е., Пушкарев П.Ю. Геоэлектрический разрез Центрального Тянь-Шаня: анализ магнитотеллурических и магнитовариационных откликов вдоль геотраверса Нарын // Физика Земли. 2010. № 8. С. 36-53].

Bielinski R.A., Park S.K., Rybin A., Batalev V., Jun S., Sears C., 2003. Lithospheric Heterogeneity in the Kyrgyz Tien Shan Imaged by Magnetotelluric Studies. Geophysical Research Letters 30 (15), 1806. https://doi.org/10.1029/ 2003 GL017455.

Bragin V.D., 2001. Active Electromagnetic Monitoring of the Bishkek Prognostic Test Area. PhD Thesis (Candidate of Physics and Mathematics). Moscow, 135 p. (in Russian) [Брагин В.Д. Активный электромагнитный мониторинг территории Бишкекского прогностического полигона: Дис. ... канд. физ.-мат. наук. М., 2001. 135 с.].

Bragin V.D., Batalev V.Yu., Zubovich A.V., Lobanchenko A.N., Rybin A.K., Trapeznikov Yu.A., Shchelochkov G.G., 2001. About Qualitative Relations of Modern Moves with an Abyssal Geoelectric Structure of Earth Crust of Central Tien Shan and Distribution of Seismicity. Russian Geology and Geophysics 42 (10), 1610-1621 (in Russian) [Бpaгин В.Д., Баталев В.Ю., Зубович А.В., Лобанченко А.Н., Рыбин А.К., Трапезников Ю.А., Щелочков Г.Г. О качественных связях современных движений с геоэлектрическим разрезом земной коры Центрального Тянь-Шаня и распределением сейсмичности // Геология и геофизика. 2001. Т. 42. № 10. С. 1610-1621].

Bragin V.D., Lobanchenko A.N., 2005. Gravity Field. In: Modern Geodynamics of Areas of Intracontinental Collisional Mountain Building (Central Asia). Nauchny Mir, Moscow, p. 52-58 (in Russian) [Брагин В.Д., Лобанченко А.Н. Гравитационное поле // Современная геодинамика областей внутриконтинентального коллизионного горообразования (Центральная Азия). М.: Научный мир, 2005. C. 52-58].

Burtman V.S., 2006. The Tien Shan and High Asia: Tectonics and Geodynamics in the Paleozoic. Proceedings of GIN RAS. Vol. 570. GEOS, Moscow, 216 p. (in Russian) [Буртман В.С. Тянь Шань и Высокая Азия: Тектоника и геодинамика в палеозое // Труды ГИН РАН. М.: ГЕОС, 2006. Вып. 570.216 с.].

Burtman V.S., 2012. Geodymanics of Tibet, Tarim, and the Tien Shan in the Late Cenozoic. Geotectonics 46, 185211. https: //doi.org/10.1134/S0016852112030028.

Buslov M.M., De Grave J., Bataleva E.A., Batalev V.Yu., 2007. Cenozoic Tectonic and Geodynamic Evolution of the Kyrgyz Tien Shan Mountains: A Review of Geological, Thermochronological and Geophysical Data. Journal of Asian Earth Sciences 29 (2-3), 205-214. https://doi.org/10.1016/j. jseaes.2006.07.001.

Chedia O.K., 1991. Kinematic Types of Active Faults. In: Modern Geodynamics of the Tien Shan Lithosphere. Nauka, Moscow, p. 65-95 (in Russian) [Чедия О.К. Кинематические типы активных разломов // Современная геодинамика литосферы Тянь-Шаня. М.: Наука, 1991. С. 65-95].

Ghose S., Hamburger M.W., Virieux J., 1998. Three-Dimensional Velocity Structure and Earthquake Locations beneath the Northern Tien Shan of Kyrgyzstan, Central Asia. Journal of Geophysical Research: Solid Earth 103 (B2), 2725-2748. https://doi.org/10.1029/97JB01798.

Giese K., Tiemann R., 1975. Determination of the Complex Permittivity from Thin-Sample Time Domain Reflectometry: Improved Analysis of the Step Response Waveform. Advances in Molecular Relaxation Processes 7 (1), 45-49. https://doi.org/10.1016/0001-8716(75)80013-7.

Grachev A.F., 1999. Early Cenozoic Magmatism and Geodynamics of North Tien Shan. Izvestiya. Physics of the Solid Earth 35 (10), 815-839.

Khain V.E., 2002. Modern Geodynamics: Achievements and Problems. Priroda 1, 51-59 (in Russian) [Хаин B.E. Coвременная геодинамика: достижения и проблемы // Природа. 2002. № 1. С. 51-59].

Kissin I.G, Ruzajkin A.I., 1997. Relationship between Seismically Active and Electrically Conductive Zones in the Crust of the Kyrgyz Tien Shan. Izvestiya, Physics of the Solid Earth 1, 21-29 (in Russian) [Киссин И.Г., Рузайкин А.И. Соотношение между сейсмоактивными и электропроводящими зонами в земной коре Киргизского ТяньШаня // Физика Земли. 1997. № 1. С. 21-29].

Knauf V.I., Mikolaichuk A.V., Khristov E.V., 1980. Structural Position of Meso-Cenozoic Volcanism of the Central Tien Shan. In: Seismotectonics and Seismicity of the Tien Shan. Ilim, Frunze, p. 3-18 (in Russian) [Кнауф В.И., Миколайчук А.В., Христов Е.В. Структурная позиция мезо-кайнозойского вулканизма Центрального Тянь-Шаня // Сейсмотектоника и сейсмичность Тянь-Шаня. Фрунзе: Илим, 1980. С. 3-18].

Kosarev G.L., Petersen N.V., Vinnik L.P., Roecker S.W., 1993. Receiver Functions for the Tien Shan Analog Broadband Network: Contrasts in the Evolution of Structures across the Talasso-Fergana Fault. Journal of Geophysical Research: Solid Earth 98 (B3), 4437-4448. https://doi.org/10.1029/ 92JB02651.

Koulakov I.Yu., 2011. High-Frequency P and S Velocity Anomalies in the Upper Mantle beneath Asia from Inversion of Worldwide Traveltime Data. Journal of Geophysical Research: Solid Earth 116, B04301. https://doi.org/10.10 29/2010JB007938.

Krestnikov V.I., Nersesov I.L., 1962. Tectonic Structure of the Pamirs and Tien Shan and Its Relationship with the Levels of the Mokhorovichich Surface. Soviet Geology 11, 36-69 (in Russian) [Крестников В.И., Нерсесов И.Л. Тектоническое строение Памира и Тянь-Шаня и его связь с рельефом поверхности Мохоровичича // Советская геология. 1962. № 11. С. 36-69].

Kumar P., Yuan X., Kind R., Kosarev G., 2005. The Lithosphere-Asthenosphere Boundary in the Tien Shan Karakoram Region from S Receiver Functions: Evidence for Continental Subduction. Geophysical Research Letters 32, L07305. https: //doi.org/10.1029/2004GL022291.

Laverov N.P., Makarov V.I. (Eds), 2005. Recent Geodynamics of Intracontinental Areas of Collision Mountain Building (Central Asia). Nauchny Mir, Moscow, 400 p. (in Russian) [Современная геодинамика областей внутриконтинентального коллизионного горообразования (Центральная 
Азия) / Ред. Н.П. Лаверов, В.И. Макаров. М.: Научный мир, 2005. 400 с.].

Leonov M.G., 1996. Geodynamic Regimes of the Southern Tien Shan in the Phanerozoic. Geotectonics 3, 36-53 (in Russian] [Леонов М.Г. Геодинамические режимы Южного Тянь-Шаня в фанерозое // Геотектоника. 1996. № 3. C. 36-53].

Leonov M.G., Przhiyalgovskii E.S., Lavrushina E.V., Rybin A.K., 2016. Postmagmatic Tectonics of Granites and Morphostructure the Northern Tien Shan. Lithosphere 6, 5-32 (in Russian) [Леонов М.Г., Пржиялговский Е.С., Лаврушина Е.В., Рыбин А.К. Постмагматическая тектоника гранитов и морфоструктура Северного Тянь-Шаня // Литосфера. 2016. № 6. С. 5-32].

Letnikov F.A., 2003. Problem of the Change of Longtitudinal Waves Velocities $\left(\mathrm{V}_{\mathrm{p}}\right)$ in the Mantle Affected by Plumes. Doklady Earth Sciences 390 (5), 673-675 (in Russian) [Летников Ф.А. К вопросу о природе изменения скоростей продольных волн $\left(\mathrm{V}_{\mathrm{p}}\right)$ в мантии, соотносимых с воздействием плюмов // Доклады АН. 2003. Т. 390. № 5. C. 673-675].

Letnikov F.A., 2006. Fluids in Endogenic Processes and Problems of Metallogeny. Russian Geology and Geophysics 47 (12), 1296-1307 (in Russian) [Летников Ф.А. Флюидный режим эндогенных процессов и проблемы рудогенеза // Геология и геофизика. 2006. Т. 47. № 12. С. 1296-1307].

Lobanchenko A.N., Kulik A.P., Kalinin L.S., 1988. Complex Geophysical Studies of Seismically Hazardous Regions (Issyk-Kul-Chuy Complex). Report. TGF, Frunze, 121 p. (in Russian) [Лобанченко А.Н., Кулик А.П., Калинин Л.С. Комплексные геофизические исследования сейсмоопасных районов (территория Иссык-Кульско-Чуйского комплекса): Отчет. Фрунзе: ТГФ, 1988. 121 с.].

Makarov V.I., 1977. Modern Tectonic Structure of the Central Tien Shan. Nauka, Moscow, 171 p. (in Russian) [Maкаров В.И. Новейшая тектоническая структура Центрального Тянь-Шаня. М.: Наука, 1977. 171 с.].

Makarov V.I., Alekseyev D.V., Batalev V.Yu., Bataleva E.A., Belyayev I.V., Bragin V.D., Dergunov N.T., Yefimova N.N. et al., 2010. Underthrusting of Tarim beneath the Tien Shan and Deep Structure of Their Junction Zone: Main Results of Seismic Experiment along MANAS Profile Kashgar-SongKöl. Geotectonics 44, 102-126. https://doi.org/10.1134/ S0016852110020020.

Mamyrov E., 2001. Elastic Properties of Crystalline Rocks in Thermodynamic Conditions of the Crust in Active Fault Zones of the Tien Shan. Ilim, Bishkek, 160 p. (in Russian) [Мамыров Э. Упругие свойства кристаллических горных пород в термодинамических условиях земной коры зон активных разломов Тянь-Шаня. Бишкек: Илим, 2001. 160 c.].

Matyukov V.E., Rybin A.K., Batalev V.Yu., Bataleva E.A., 2014. Deep Geoelectric Structure and Seismicity of the PamirAlai Zone. In: Problems of Geodynamics and Geoecology of Intracontinental Orogens. Abstracts of the Sixth International Symposium (June 23-29, 2014). Research Station RAS, Bishkek, p. 200-201 (in Russian) [Матюков B.E.,
Рыбин А.К., Баталев В.Ю., Баталева Е.А. Глубинная геоэлектрическая структура и сейсмичность Памиро-Алайской зоны // Проблемы геодинамики и геоэкологии внутриконтинентальных орогенов: Тезисы докладов Шестого Международного симпозиума (23-29 июня 2014 г.). Бишкек: НС РАН, 2014. С. 200-201].

Melnikova T.A., 1991. Maps of Total Longitudinal Conductivity of Meso-Cenozoic Deposits in Intermontane Depressions of Kyrgyzstan. In: F.N. Yudakhin (Ed.), Structure of the Tien Shan Lithosphere. Ilim, Bishkek, p. 100-111 (in Russian) [Мельникова T.A. Карты суммарной продольной проводимости мезо-кайнозойских отложений межгорных впадин Киргизии // Строение литосферы Тянь-Шаня / Ред. Ф.Н. Юдахин. Бишкек: Илим, 1991. C. 100-111].

Mossakovsky A.A., Ruzhentsev S.V., Samygin S.G., Kheraskova T.N., 1993. The Central Asian Fold Belt: Geodynamic Evolution and History of Formation. Geotectonics 6, 3-32 (in Russian) [Моссаковский А.А., Руженцев С.В., Самыгин С.Г., Хераскова Т.Н. Центрально-Азиатский складчатый пояс: геодинамическая эволюция и история формирования // Геотектоника. 1993. № 6. С. 3-32].

Nepeina K.S., 2018a. Review of Modern Practice of Seismometers Grouping on the Example of Central Asia. In: Modern Scientific Research Techniques and Technologies. Materials of the 10th International Conference of Young Scientists and Students (April 18-20, 2018). Research Station RAS, Bishkek, p. 85-90 (in Russian) [Непеина К.C. Обзор современной практики использования группирования сейсмометров на примере Средней Азии // Современные техника и технологии в научных исследованиях: Сборник материалов Х Международной конференции молодых ученых и студентов (18-20 апреля 2018 г.). Бишкек: НС РАН, 2018. С. 85-90].

Nepeina K.S., 2018b. Seismological Network Observations in Central Asia. Bulletin of NNC RK 2, 107-115 (in Russian) [Непеина К.С. Сети сейсмических наблюдений в Центральной Азии // Вестник НЯЦ РК. 2018. Вып. 2. C. 107-115].

Nusipov E.N., Ospanov A.B., Shatsilov V.I., 2005. Velocity Models of the Lithosphere of High Asia Using the System of Geotraverses. NNC RK Bulletin 2, 109-121 (in Russian) [Нусипов Е.Н., Оспанов А.Б., Шацилов В.И. Скоростные модели литосферы Высокой Азии по системе геотраверсов // Вестник НЯЦ РК. 2005. Вып 2. С. 109-121].

Omuralieva A., Nakajima J., Hasegawa A., 2009. ThreeDimensional Seismic Velocity Structure of the Crust beneath the Central Tien Shan, Kyrgyzstan: Implications for Largeand Small-Scale Mountain Building. Tectonophysics 465 (14), 30-44. https://doi.org/10.1016/j.tecto.2008.10.010.

Pogrebnoi V.N., Grebennikova V.V., 2012. Features of the Tectonic Structure of the Moho Surface in the Kyrgyz Tien Shan According to Gravity Data. In: Modern Problems of Geodynamics and Geoecology of Intra-Continental Orogens. To the 75th Anniversary of Yu.A. Trapeznikov. Proceedings of the 5th International Symposium (June 19-24, 2011). Bishkek, p. 100-105 (in Russian) [Погребной В.Н., Гребенникова В.В. Особенности тектонической структуры 
поверхности Мохо на территории Кыргызского ТяньШаня по гравитационным данным // Современные проблемы геодинамики и геоэкологии внутриконтинентальных орогенов к 75-летию со дня рождения Ю.А. Трапезникова: Материалы докладов V Международного симпозиума (19-24 июня 2011 г.). Бишкек, 2012. C. 100-105].

Pogrebnoi V.N., Grebennikova V.V., Mamyrov E., Makhankova V.A., 2009. Features of the Geological and Tectonic Structure in Geophysical Fields and Seismic Activity of Southern Kyrgyzstan. In: Geodynamics of Intracontinental Orogens and Geoecological Problems. Proceedings of the Fourth International Symposium (June 15-20, 2008). Vol. 4. Research Station RAS, Moscow - Bishkek, p. 210-214 (in Russian) [Погребной B.Н., Гребенникова В.В., Мамыров Э., Маханькова В.А. Особенности геолого-тектонического строения в геофизических полях и сейсмическая активность Южного Кыргызстана // Геодинамика внутриконтинентальных орогенов и геоэкологические проблемы: Тезисы докладов 4-го Международного симпозиума (15-20 июня 2008 г.). Бишкек, 2009. C. 210-214].

Pogrebnoi V.N., Sabitova T.M., 2001. Manifestation of the Tibet Plume Structure and Seismicity of High Asia in Regional Geophysical Fields. Russian Geology and Geophysics 10, 1532-1542 (in Russian) [Погребной В.Н., Сабитова Т.М. Отражение структуры Тибетского плюма и сейсмичности Высокой Азии в региональных геофизических полях // Геология и геофизика. 2001. № 10. C. 1532-1542].

Roecker S.W., Sabitova T.M., Vinnik L.P., Burmakov Y.A., Golvanov M.I., Mamatkanova R., Munirova L., 1993. ThreeDimensional Elastic Wave Velocity Structure of the Western and Central Tien-Shan. Journal of Geophysical Research: Solid Earth 98 (B9), 15779-15795. https://doi.org/10.10 29/93JB01560.

Rybin A.K., 2001. Deep Electromagnetic Sounding in the Central Part of the Kyrgyz Tien Shan. Brief PhD Thesis (Candidate of Physics and Mathematics). Moscow, 24 p. (in Russian) [Рыбин А.К. Глубинные электромагнитные зондирования в центральной части Киргизского ТяньШаня: Автореф. дис. ... канд. физ.-мат. наук. М.: МГУ, 2001. 24 c.].

Rybin A.K., 2010. Magnitotelluric and Seismic Researches on Transect MANAS (Central Tien Shan). Proceedings of Voronezh State University. Series: Geology 1, 218-228 (in Russian) [Рыбин А.К. Магнитотеллурические и сейсмические исследования по трансекту MANAS (Центральный Тянь-Шань) // Вестник Воронежского государственного университета. Серия: Геология. 2010. № 1. C. 218-228].

Rybin A.K., 2011. Deep Structure and Modern Geodynamics of the Central Tien Shan According to the Results of Magnetotelluric Studies. Nauchny Mir, Moscow, 256 p. (in Russian) [Рыбин А.К. Глубинное строение и современная геодинамика Центрального Тянь-Шаня по результатам магнитотеллурических исследований. М.: Научный мир, 2011. 256 с.].
Rybin A.K., Batalev V.Yu., Bataleva E.A., Matyukov V.E., 2009. Magnetotelluric Evidence of Deep Geodynamic Settings at the Junction Zone of the Southern Tien Shan and Tarim Basin. Journal of Mining Institute 183, 272-276 (in Russian) [Рыбин А.К., Баталев В.Ю., Баталева Е.А., Матюков В.Е. Магнитотеллурические свидетельства глубинных геодинамических условий в зоне сочленения Южного Тянь-Шаня и Тарима // Записки Горного института. 2009. Т. 183. С. 272-276].

Rybin A.K., Batalev V.Yu., Il'chev P.V., Shchelochkov G.G., 2001. Magnetotelluric and Magnetic Variational Studies of the Kyrgyz Tien Shan. Russian Geology and Geophysics 10, 1566-1573 (in Russian) [Рыбин А.К., Баталев В.Ю., Ильичев П.В., Щелочков Г.Г. Магнитотеллурические и магнитовариационные исследования Киргизского Тянь-Шаня // Геология и геофизика 2001. № 10. С. 1566-1573].

Rybin A.K., Leonov M.G., Przhiyalgovskii E.S., Batalev V.Yu., Bataleva E.A., Bragin V.D., Morozov Yu.A., Schelochkov G.G., 2016. Nature of Electric Conductive Layers of the Upper Crust and Infrastructure of Granites of the Central Tien Shan. Doklady Earth Sciences 470, 968-971. https://doi. org/10.1134/S1028334X16090142.

Rybin A.K., Matyukov V.E., Batalev V.Yu., Bataleva E.A., 2019. Deep Geoelectric Structure of the Earth's Crust and the Upper Mantle of the Pamir-Alai Zone. Russian Geology and Geophysics 60 (1), 108-118. https://doi.org/10.153 72/RGG2019008.

Rybin A.K., Spichak V.V., Batalev V.Yu., Bataleva E.A., Matyukov V.E., 2008. Array Magnetotelluric Soundings in the Active Seismic Area of Northern Tien Shan. Russian Geology and Geophysics 49 (5), 337-349. https://doi.org/10. 1016/j.rgg.2007.09.014.

Sabitova T.M., 1978. The Crustal Structure in the Zone of Transition from the Northern to Middle Tien Shan According to Seismological Data. In: Geological and Geophysical Characteristics of Seismogenic Zones of Kyrgyzstan. Ilim, Frunze, p. 4-21 (in Russian) [Сабитова Т.М. Строение земной коры зоны, переходной от Северного к Срединному Тянь-Шаню, по сейсмологическим данным // Геолого-геофизическая характеристика сейсмогенных зон Киргизии. Фрунзе: Илим, 1978. С. 4-21].

Sabitova T.M., 1989. The Crustal Structure of the Kyrgyz Tien Shan According to Seismological Data. Ilim, Frunze, 174 p. (in Russian) [Сабитова T.M. Строение земной коры Киргизского Тянь-Шаня по сейсмологическим данным. Фрунзе: Илим, 1989. 174 с.].

Sabitova T.M., Adamova A.A., 2001. Seismotomographic Studies of the Tien Shan Crust. Results. Problems. Prospects. Russian Geology and Geophysics 42 (10), 1543-1553 (in Russian) [Сабитова T.M., Адамова А.А. Сейсмотомографические исследования земной коры Тянь-Шаня. Результаты. Проблемы. Перспективы // Геология и геофизика. 2001. Т. 42. № 10. С. 1543-1553].

Sabitova T.M., Adamova A.A., Medjitova Z.A., Bagmanova N.Kh., 2003. Velocity Structure Features of Northern TienShan Crust. In: Abstracts of the XXIII General Assembly of the International Union of Geodesy and Geophysics (July 7-11, 2003). Sapporo, Japan, p. 485. 
Sabitova T.M., Bagmanova N.Kh., Mirkin E.L., 2009. Velocity Heterogeneities of the Tien Shan Lithosphere in Connection with Geodynamics and Seismicity. In: Geodynamics of Intracontinental Orogens and Geoecological Problems. Proceedings of the Fourth International Symposium (June 15-20, 2008). Vol. 4. Research Station RAS, Moscow Bishkek, p. 406-415 (in Russian) [Сабитова T.M., Багманова Н.Х., Миркин Е.Л. Скоростные неоднородности литосферы Тянь-Шаня в связи с геодинамикой и сейсмичностью // Геодинамика внутриконтинентальных орогенов и геоэкологические проблемы: Сборник материалов четвертого международного симпозиума (1520 июня 2008 г.). Москва - Бишкек: НС РАН, 2009. Вып. 4. C. 406-415].

Sabitova T.M., Medzhitova Z.A., Bagmanova N.Kh., 2006. Reflection of Geodynamic Processes in the Velocity Structure of the Crust and Upper Mantle Layer of the Tien Shan. In: Geodynamics and Geoecology of High-Mountain Regions of the Tien Shan in the XXI century. Proceedings of the Third International Symposium (October 30 - November 06, 2005). Vol. 1. Research Station RAS, Bishkek, p. 101108 (in Russian) [Сабитова T.М., Меджитова 3.А., Багманова Н.Х. Отражение геодинамических процессов в скоростной структуре земной коры и верхнемантийного слоя Тянь-Шаня // Геодинамика и геоэкология высокогорных регионов Тянь-Шаня в XXI веке: Материалы Третьего Международного симпозиума (30 октября - 6 ноября 2005 г.). Бишкек: НС РАН, 2006. Вып. 1. C. 101-108].

Sass P., Ritter O., Ratschbacher L., Tympel J., Matiukov V. E., Rybin A. K., Batalev V. Yu., 2014. Resistivity Structure underneath the Pamir and Southern Tian Shan. Geophysical Journal International 198 (1), 564-579. https://doi.org/10. 1093/gji/ggu146.

Schneider F.M., Yuan X., Schurr B., Mechie J., Sippl C., Haberland C., Minaev V., Oimahmadov I. et al., 2013. Seismic Imaging of Subducting Continental Lower Crust beneath the Pamir. Earth Planet Scientific Letters 375 (1), 101-112. https://doi.org/10.1016/j.epsl.2013.05.015.

Shmonov V.M., Vitovtova V.M., 2017. Rock Permeability and Fluid Density in High-Temperature Geochemical Processes (Experimental Studies). Nauchny Mir, Moscow, 294 p. (in Russian) [Шмонов В.М., Витовтова В.М. Проницаемость пород и плотность флюидов в высокотемпературных геохимических процессах (экспериментальные исследования). М.: Научный мир, 2017. 294 с.].

Shmonov V.M., Vitovtova V.M., Grafchikov A.A., Kotelnikov A.R., Sretenskaya N.G., 2000. Relationship between Electrical Conductivity and Rock Permeability of Continental Crust (Estimates from Experimental Data). Izvestiya, Physics of the Solid Earth 3, 65-70 (in Russian) [Шмонов В.М., Витовтова В.М., Графчиков А.А., Котельников А.Р., Сретенская Н.Г. Взаимосвязь электропроводности и проницаемости пород в условиях континентальной земной коры (оценка по экспериментальным данным) // Физика Земли. 2000. № 3. С. 65-70].

Sychev I.V., Koulakov I.Yu., Sycheva N.A., Koptev A., Medved I., El Khrepy S., Al-Arifi N., 2018. Collisional Processes in the Crust of the Northern Tien Shan Inferred from Velocity and Attenuation Tomography Studies. Journal of Geophysical Research: Solid Earth 123 (2), 1752-1769. https://doi. org/10.1002/2017JB014826.

Tal-Virsky B.B., 1982. Geophysical Fields and Tectonics of Central Asia. Nedra, Moscow, 396 p. (in Russian) [ТальВирский Б.Б. Геофизические поля и тектоника Средней Азии. М.: Недра, 1982. 396 с.].

Trapeznikov Yu.A., Andreyeva E.V., Batalev V.Yu., Berdichevskiy M.N., Vanyan L.L., Volykhin A.M., Golubtsova N.S., Rybin A.K., 1997. Magnetotelluric Soundings in the Kyrgyz Tien Shan. Izvestiya. Physics of the Solid Earth 33 (1), 1-17.

Treusov A.V., Sabitova T.M., Golovanov M.I., 1993. Tomographic Model of the Tien Shan Crust. Izvestiya, Physics of the Solid Earth 10, 89-98 (in Russian) [Треусов А.В., Сабитова Т.М., Голованов М.И. Томографическая модель коры Тянь-Шаня // Физика Земли. 1993. № 10. С. 89-98].

Vinnik L.P., 1998. Seismic Properties of Mantle Plumes. Vestnik OGGGGN RAN (Bulletin of the Section of Geology, Geophysics and Mining Sciences RAS) 3 (5), 194-202 (in Russian) [Винник Л.П. Сейсмические свойства мантийных плюмов // Вестник ОГГГГН РАН. 1998. Т. 3. № 5. C. 194-202].

Vinnik L.P., Aleshin I.M., Kaban M.K., Kiselev S.G., Kosarev G.L., Oreshin S.I., Reigber Ch., 2006. Crust and Mantle of the Tien Shan from Data of the Receiver Function Tomography. Izvestiya. Physics of the Solid Earth 42, 639-651. https://doi.org/10.1134/S1069351306080027.

Vinnik L.P., Reigber C., Aleshin I.M., Kosarev G.L., Kaban M.K., Oreshin S.I., Roecker S.W., 2004. Receiver Function Tomography of the Central Tien Shan. Earth Planet Scientific Letters 225 (1-2), 131-146. https://doi.org/10.10 16/j.epsl.2004.05.039.

Vinnik L.P., Roecker S., Kosarev G.L., Oreshin S.I., Koulakov I., 2002. Crustal Structure and Dynamics of the Tien Shan. Geophysical Research Letters 29 (22), 2047. https:// doi.org/10.1029/2002gl015531.

Volvovsky B.S., Tal-Virsky B.B., 1977. Technique of Deep Seismic Studies in the Pamirs and Tien Shan. In: The Structure of the Crust and Upper Mantle Structure According to Seismic Data. Naukova Dumka, Kiev, 230-236 (in Russian) [Вольвовский Б.С., Таль-Вирский Б.Б. Методика глубинных сейсмических исследований на Памире и Тянь-Шане // Строение земной коры и верхней мантии по данным сейсмических исследований. Киев: Наукова думка, 1977. C. 230-236].

Windley B.F., Alexeiev D.V., Xiao W., Kröner A., Badarch G., 2007. Tectonic Models for Accretion of the Central Asian Orogenic Belt. Journal of the Geological Society 164 (1), 3147. https://doi.org/10.1144/0016-76492006-022.

Yudakhin F.N., 1983. Geophysical Fields, Deep Structure and Seismicity of the Tien Shan. Ilim, Frunze, 247 p. (in Russian) [Юдахин Ф.Н. Геофизические поля, глубинное строение и сейсмичность Тянь-Шаня. Фрунзе: Илим. 1983. 247 c.].

Yudakhin F.N., 1986. On the Dynamics of the Tien Shan Lithosphere in the Light of a Complex of Geophysical Data. 
In: Lithosphere of the Tien Shan. Nauka, Moscow, p.142145 (in Russian) [Юдахин Ф.Н. К вопросу о динамике литосферы Тянь-Шаня в свете комплекса геофизических данных // Литосфера Тянь-Шаня. М.: Наука, 1986. C. 142-145].

Yudakhin F.N., Shvartsman Yu.G., Lobanchenko A.N., 1991. The Lithosphere Section from the Complex of Data. In: Modern Geodynamics of the Tien Shan Lithosphere. Nauka, Moscow, p. 57-60 (in Russian) [Юдахин Ф.Н., Шварцман Ю.Г., Лобанченко А.Н. Разрез литосферы по комплексу данных // Современная геодинамика литосферы Тянь-Шаня. М.: Наука, 1991. С. 57-60].

Zabelina I.V., Koulakov I., Buslov M.M., 2013. Deep Mechanisms in the Kyrgyz Tien Shan Orogen (from Results of Seismic Tomography). Russian Geology and Geophysics 54 (7), 695-706. https://doi.org/10.1016/j.rgg.2013.06.005.

Zhao J., Liu G., Lu Z., Zhang X., Zhao G., 2003. Lithospheric Structure and Dynamic Processes of the Tianshan Orogenic
Belt and the Junggar Basin. Tectonophysics 376 (3-4), 199239. https://doi.org/10.1016/j.tecto.2003.07.001.

Zhiwei L., Roecker S., Zhihai L., Bin W., Haitao W., Schelochkov G., Bragin V., 2009. Tomographic Image of the Crust and Upper Mantle beneath the Western Tien Shan from the MANAS Broadband Deployment: Possible Evidence for Lithospheric Delamination. Tectonophysics 477 (1-2), 4957. https://doi.org/10.1016/j.tecto.2009.05.007.

Zubovich A.V., Trapeznikov Yu.A., Bragin B.D., Mosienko O.I., Shchelochkov G.G., Rybin A.K., Batalev V.Yu., 2001. Deformation Field, Deep Structure of the Crust, and Spatial Seismicity Distribution in the Tien Shan. Russian Geology and Geophysics 42 (10), 1634-1640 (in Russian) [Зубович А.В., Трапезников Ю.А., Брагин В.Д., Мосиенко О.И., Щелочков Г.Г., Рыбин А.К., Баталев В.Ю. Поле деформаций, глубинное строение земной коры и пространственное распределение сейсмичности Тянь-Шаня // Геология и геофизика. 2001. Т. 42. № 10. С. 1634-1640]. 